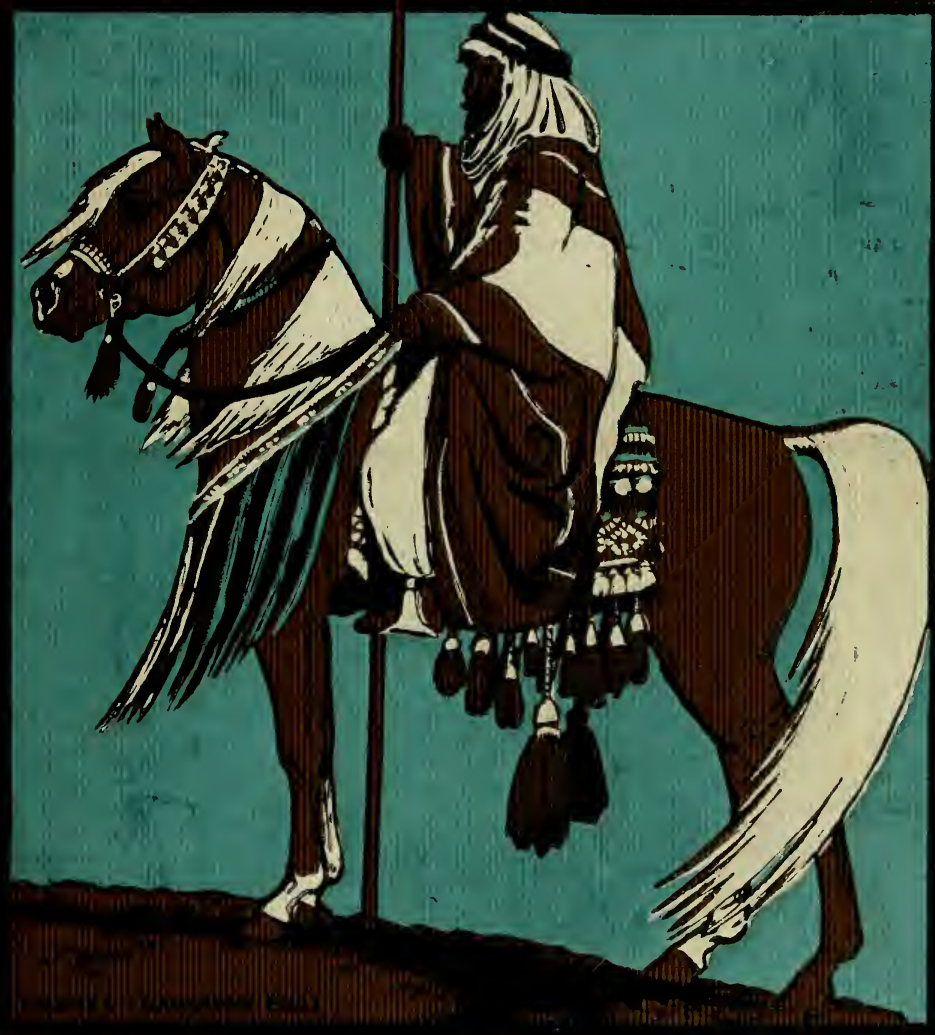




\section{6) $\frac{8}{5}$}

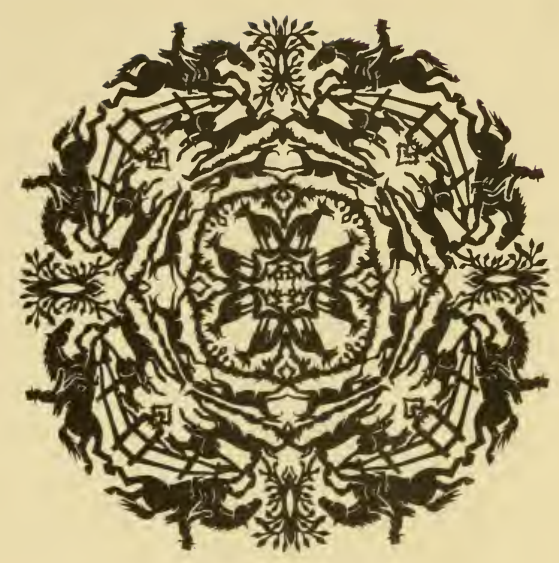

JOHN A.SEAVERNS 


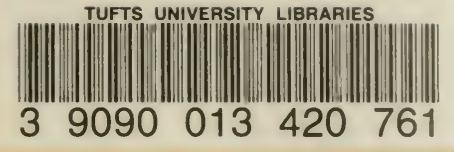

1

Webster Family Library of Veterinary Medicine Cummings School of Veterinary Medicine at

Tuts University

200 Westboro Road

North Grafton, MA 01536 






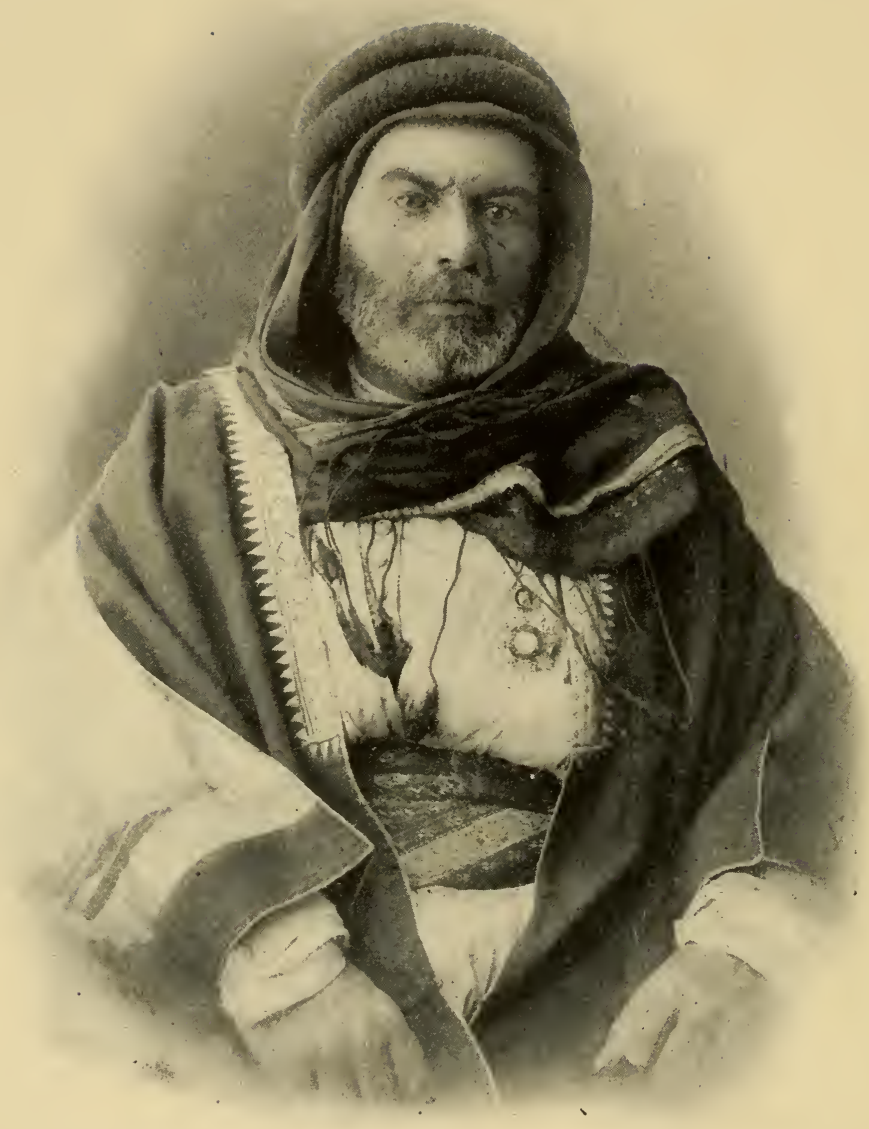

Sheikh Achmet Haffez, "My Bedouin Brother," the diplomatic ruler of the Anezeh Bedouins.

This photograph was taken by the Hon. J. B. Jackson, the first American Consul in Aleppo, in 1908. It shows the distinguished old diplomat with a beard grown since our visit in 1906; it also reveals the medal from the Sultan of Turkey. 


\title{
MY QUEST OF THE
}

ARAB HORSE

\author{
BY \\ HOMER DAVENPOR'T
}

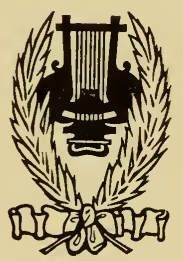

NEW YORK

B. W. DODGE \& COMPANY 1909 
Copyright, 1909, by

B. W. DODGE \& COMPANY

Registered at Stationers' Hall, London ( All Rights Reserved)

Printed in the United States of America 


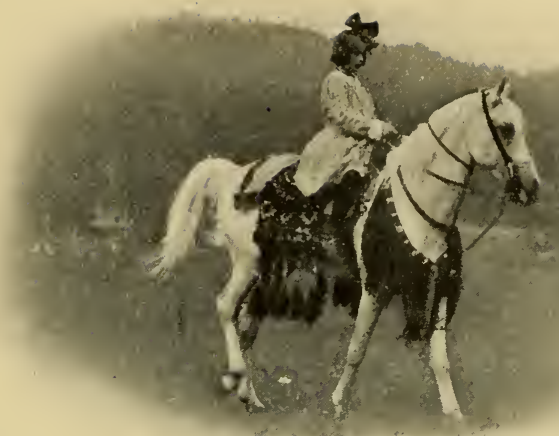

DEDICATED TO

My Daughter Mildied 



\section{TABLE OF CONTENTS}

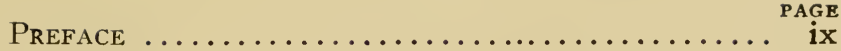

Chapter An OREgon ARAB and What It Led to.... I

II Procuring the Iradé and the Start for the Desert...................... 9

III The Sultan's Stables............... I9

IV The Sultan of Turkey.............. 28

V From Constantinople to Antioch....... 50

VI Antioch to Aleppo................. 6

VII Akmet Haffez and the War Mare...... 77

ViII The War Mare Greets the Desert..... 90

IX We Feast with the Anezeh and Become Better Acquainted - Inspection and Purchase of Horses................ I05

$\mathrm{X}$ An Important Ceremony in Which I Was One of the Principals-A Circassian Village, with a Visit to the Governor, and What Befell Sheikh Ali....... I23

XI As to Dogs and as to One Dog in ParTICULAR ...................... 136

XiI The Meeting with Hashem Bey, the Great Sheikh of the Desert......... I50

XiII Starting on the Return Journey and Some Oriental Bargaining-The BeginNing of the Story of the Mare....... I67

$$
\text { [ix ] }
$$




\section{TABLE OF CON'TEN'TS}

CHAPTER PAGE

XiV Another Present - Hassan T a s h i N

Pasha and His Horses............. I75

XV We Say Farewell to Akmet Haffez and

Start for the Coast- "The Pride of the Euphrates" Comes to Us at Last and Meets Her Two Sons.............. I84

XVI What One May Overlook in the ShipMENT of Horses-We Leave the OtToman Empire and Enter Essential Part of It at Least, Although Surrounded By Spies ....................... I97

XVII Naples and Some of the Misfortunes WHICH OverTOOK US THERE-AMERICA AT LAST ................... 2 I0

XVIII Of Said Abdallah and His Notions of

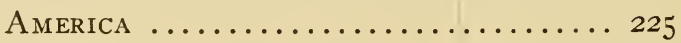

XiX The Bedouin of the Desert, His Son and His Daughter, His Cattle and the Stranger That Is Within His Gates... 233

XX The Arab Horse and His Present Status -Some Stories from the Desert...... 247

XXI Various Importations of Arab Horses.... 268 


\section{LIST OF ILLUSTRATIONS}

Sheikh Akmet Haffez, the Diplomatic Ruler of the Anezeh Bedouins............. Frontispiece His Excellency Chikeb Bey, the Turkish AmBASSADOR ...................... II

Letter of Chikeb Bey.................... i6

Abdul Hamid's Favorite Horse.............. 22

The Sultan, Abdul Hamid................ 27

"It Was a Rare Treat for the Diplomats When We Lined Up for Admission to the Palace”.... 3 3

A Royal Eunuch........................ 34

Royal Eunuchs Following the Carriages of the Princesses ....................... 37

Abdul Hamid Is Greeted by His Two Sons at the MosQue ......................... 42

The Sultan Returning from the Mosque...... 46

A meen Zaytoun, My Interpreter............ 53

One of Our Escorts at Antioch............. 62

Old Methods of Travel Giving Way to New in Aleppo .............................. 74

My Royal Present, Wadduda the War Mare, with

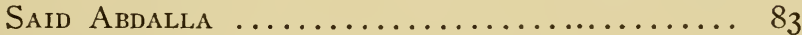

Nazin Pasha, the Governor of Alepro......... 87

Haleb, the Pride of the Anezeh............. 9I

Our First Round of Coffee Under the Great Sheikh's Tent ..................... I0 3 Our Tent Near the Great Sheikh's Tent Among the Anezeh ......................... IO 7 "Just Out of Our Tent Squatted This Young Anezeh Bedouin" .................... II I Young Men of the Anezeh Seeing Their First Cameras ......................... II 3 The Method of Buying a Horse in the Desert.... i í6 [xi] 


\section{LIST OF ILLUSTRATIONS}

A Gomussa Bedouin of the SabBa A Page "Akmet Haffez Would Join Our Hands Just BeFore the Horse Was Bought"............ I2I Abeyah's Pedigree ................... I 25

Drinking Sour Sheep and Camel's Milk with Akmet Haffez ..................... I27

Sheikh Ali Rashid of the Abo-Gomese......... I 29

A Handsome Bedouin Boy............... I3I

The Supreme Sheikh, Hashem Bey.......... I 50

The Sheikh of All Sheikhs............. I52

Pedigree of Haleb, the Brown Maeghi Sbeyl.... I54 An Old Warrior of the Anezeh............ I56 "This Expressionless Old Horseman".......... I 58

Photographed with the Great Sheikhs of the

Fedan Anezeh ................... I6I

Haleb's Head...................... I6

Curious Visitors Much Astonished at Watching

Me Sketch ..................... I68

Hamrah, a Seglawie-Jedran.............. I69

Our Camp a Few Miles East of Aleppo........ I73

Euphrates, Full Brother to Hamrah........ I76

Muson, Light Gray Stallion............. I79

Hassan Tasshin Pasha, Exiled in Aleppo....... I8I

Study of Muson-Still, Listening.......... I85

Muson, the Kehilan Muson............... I9I

BriHEM PASHA ..................... I95

"No Horses Were More Sensible Than These

While Being Transferred from Steamer to BARGE" ......................... $2 \mathrm{I} 2$

Transferring a Horse from Barge to Steamer at

NAPLES . ...................... 219

One of the Young Men of the Anezeh........ 234

An Old Bedouin from the Sabba Anezeh....... 235

Camels for the Royal Daughters........... 243

A Seglawie-Jedran of Ibn-ed-Eddara.......... 249

Paring the Frog of the Horse's Foot Out Prior

to Putting On the Shok................ 253

Showing tile Solid Steel Shoe with Small Hole

in Center .......................... 254 


\section{PREFACE}

THis book has not been written with any idea that it will add to literature. Indeed, my primary object in going to the Syrian desert was not to see things and then over-describe them in a book; I had no use for souvenir spoons or Turkish rugs. My purpose was but for one thing, and that was to obtain Arab mares and stallions of absolute purity of blood that I could trace as coming from the great Anezeh tribe of Bedouins. That was my fixed idea in undertaking the journey.

I had been deeply interested in the Arab horse for many years before I really knew anything about them. Then, when I thought I had begun to acquire some knowledge of the breed I found that I was not learning much. Information about them, obtainable in this country, was confusing; alleged authorities contradicted each other in every argument; the thing to do, it seemed to me, was to go myself to the home of the Arab horse and there learn of him from his master, the Bedouin.

[ xiii ] 


\section{PREFACE}

The journey thus was undertaken also for my own education and that it was so successful (if I may be permitted to say so) is largely due to aid received from several influential quarters. I carried with me, for instance, letters from President Roosevelt, who, as a horseman, ranks with his standing as a man, and without which my errand would have been fruitless. From His Imperial Majesty, the Sultan of Turkey, I received an Irade, together with the courtesies of the Sublime Porte. In Aleppo I had the extreme good fortune to form a bond of true friendship with the venerable Achmet Hafez, himself the Prince of all the Bedouins. By him personally I was taken to the desert and personally he interested himself in my purchases of horses. Without him it would have been an accident if $I$ had been able to purchase a single animal of absolute purity of blood. It was these unusual courtesies that brought success to the undertaking and to all that extended them a sincere and hearty acknowledgment is here made.

Thanks also are due and are here expressed to Charles Arthur Moore, Jr., and to the late John Henry Thompson, Jr., who were my companions on the trip and whose hearty co- 


\section{PREFACE}

operation was an invaluable aid in achieving its ends. Acknowledgments are also made to the Woman's Home Companion for permission to reprint from its pages much of the matter and many of the pictures used in this volume.

To repeat again what has been said above, my journey had this serious purpose in viewthat by a judicious use of the pure Arabian blood, a breed of horse might be re-established as useful to mankind as was the Morgan horse when it was at its greatest. But, I had to get to the desert before I could purchase my horses and getting to the desert under the circumstances, proved even more interesting and romantic than I had expected. That may sound foolish. In these days, when an automobile honk-honks through the bazaars of Damascus, and when a trolley car clangs under the old city gate over the pilgrim road to Mecca; when you journey most of the way to Mecca itself on one railway and when you travel to the ruins of Baalbek on another, there does not seem to be much romance left.

But after you have been in the East for a while you will find, as I did, that all the hustle and bustle imparted from the Occident speedily

$$
[\mathrm{xv} \text { ] }
$$




\section{PREFACE}

become orientalized; there is always plenty of time at the other end of the Mediterranean.

It is always "Bookra" (to-morrow) there. A through "express" train stops to allow the passengers to see an exciting fight between two fellaheen on a threshing floor; during the combat the conductor offers to you or accepts from you a cigarette, and it is quite as often the former as the latter. Imagine the 18-hour limited slowing up because two farm hands near Palatine Bridge were having a set-to! Think of the Pullman conductor exchanging cigars with you!

Even in Constantinople, where one might expect to find something of the energy of the West, the story is the same. You walk down the gangplank from the French steamer moored just above the north of the Golden Horn and-Bookra! Why be in a hurry? Is there not a Bookra? Curiously enough, after you have heard that dinned into your ears enough times you begin to say to yourself: "Of course I am not in a hurry. There Is a Bookra." And then you can really be part of the East.

When you get back to America you realize [xvi ] 


\section{PREFACE}

that this feeling has been more one of laziness and inertia than of romance. It has been, you are perfectly certain, just a response to your environment. You are apt to wonder how you ever could have yielded to it, but still you are 'way sure that it was the only thing you could have done at the time.

Even now, writing in Morris Plains, I find myself thinking and almost believing that I am again in the desert. I smell its smells and hear its sounds. Under the tents of the Anezeh my companions and I sit in the evening silently drinking the salted coffee and smoking the pipe passed around from hand to hand; for half hours at a time no one speaks-we only hear the querulous jackals snarling over a bit of offal on the outskirts of the camp; once in a while some old Chief of the Tribe softly calls upon Allah.

Again in my thoughts I renew the bond of brotherhood with Achmet Hafez and begin all over again my friendship with Hashim Bey, the Sheikh of all the Sheikhs of the Bedouins.

It has been impossible for me, therefore, not to include in this book some of the romance of the desert and of the journey to it. I only [xvii] 


\section{PREFACE}

hope that the stories of the happenings which interested me will interest those who may read what follows, even if they are not horsemen.

\section{Homer Davenport.}

Morris Plains, N. J. 


\section{My Quest of the Arab Horse}

\section{CHAP'TER I}

AN OREGON ARAB AND WHAT IT LED TO

The real story of my trip to the Syrian desert begins in Oregon in 1871.

At Christmas time of that year I received a box of paints, and a few days after, at the age of three years and nine months, I drew an illustration which was known all through my boyhood as "Arabian Horses." I believed then that Arabian horses were spotted, like leopards, an idea that I had evidently obtained from circuses. However, it shows the tail carried high, and this was a correct impression that must have been conveyed to me by $\mathrm{my}$ parents. Indeed the following letter from my father shows that he used to tell me of Arab horses:

$$
\text { "Silverton, Nov. 11, } 1906 .
$$

"I cannot fix the exact time when I began to tell you stories of the Arab and his horse, but it 


\section{MY QUEST OF THE ARAB HORSE}

was when you were housed up in the winter of '70-'71. All through the inclement weather you had horse on the brain and I pictured to you the Arab as an equestrian, mounted upon his glorious steed, his desert born companion that shared with him his tent and food and aspirations.

"Although you were but three years and nine months old, you exhausted my store of knowledge relating to human and horse life in Arabia. You seemed to be specially interested in the way the Arab horse carried his head and tail; to ask if it was like 'Old John." "

I only relate this early evidence to show that this trip to the desert was the realization of a boy's dream. Ever since the drawing of this picture of Arab horses, I have had in mind Arab horses, and I have always been easily stopped on any street corner, or crossroad, by a story pertaining to the Arab or his horses, and hour after hour of valuable time I have spent in drawing the Arab horse or in talking about him.

I must have been in my teens, when a great revival of interest in the Arab came along with the appearance in Silverton, Oregon, of a can 


\section{AN OREGON ARAB}

bearing a label with a very beautiful picture of a white Arab horse, having his shin bone treated with what the can had once held. That the liniment had gone, did not bother me at all. I carefully removed the stains on the cover of the can without soiling the lithograph, and that can formed my only piece of artistic furniture for a number of years. I remember that for a time $I$ had in mind that I would keep the can, and, in later life, when I began to accumulate artistic treasures I could build around it. But in 1892, when I was compelled by relatives to leave Oregon for San Francisco, the horse liniment can was left in the woodshed, much against my will.

In 1893, however, at Chicago, just before the opening of that World's Fair, the Arab germs in my system got a fresh start. I was going with a reporter on some detail, while employed on the Chicago Herald, when, on State Street, we heard some weird, queer music. Approaching us were some gray horses slipping and falling on the wet pavement; horses that actually had grace and beauty as they fell and regained their feet almost instantaneously.

Though never having before seen a horse with a speck of Arab blood in his veins, I knew [3] 


\section{MY QUEST OF THE ARAB HORSE}

that these were Arab horses. I told the reporter to wait and I would be back in a minute. It was a long moment; I followed those horses -up one street and down another, until they finally arrived back at their headquarters. Here, with about eight thousand small boys, I was stopped at the outside gate while the horses, with big sparkling eyes and gracefully carried tails, pranced in. The majority of them were grays, and I thought (my fouryear-old drawing was in mind) it was very strange that there were no spotted ones.

During the next few days I thought of noththing else but these horses and dreamed of nothing else during the nights. After a week or so it commenced to worry me, but finally the fair opened, and after it had been running a few weeks, this Bedouin camp was exhibited on the "Midway."

In these days I drew nothing but horse pictures, for I was on the Herald for that purpose. I had been illustrating the Washington Park races, and had made the acquaintance of Alf and William Lakeland. The first was the famous trainer of thoroughbreds, who was in Chicago with the horses of Mr. James R. Keene. His brother William was simply there

$$
\text { [4] }
$$




\section{AN OREGGN ARAB}

with open ears and loose change, listening for the best tips. One day I went to the stalls in the Bedouin camp and made a sketch of a gray stallion they called Obeyran. I finished the picture in pen and ink, and showed it to the Lakelands. They thought I ought to get one of the smaller horses in exchange for it, while I had made up my mind to be content if they would give me a saddle and bridle that had actually been on one of the horses, as I had learned that all the animals had to be returned to the desert near Damascus, whence they had come by special permission of the Sultan of Turkey.

The Lakelands went with me to present the picture. I had stupidly drawn it while the horse was in his stall, with the tail hanging as an ordinary horse's tail would hang. The Bedouins recognized the picture, and most of them exclaimed "Obeyran!" but in a moment there was a rumpus raised because the tail was carried low. One of them struck the picture with a sword and cut it in two, and another ripped at it, and finally it was knocked out of my hands and torn in pieces. The Lakelands and myself were thrown bodily out of the en- 


\section{MY QUEST OF THE ARAB HORSE}

closure. There was a Syrian in the party who could talk English, and he explained to us that these town Arabs had misunderstood our intention and thought that the picture had been made as an insult to their horses. This was quite a disappointment indeed. The Lakelands were entirely discouraged, but it only stopped me for a few days.

Notwithstanding the want of appreciation given to my efforts as an artist, I was soon back as a regular customer, paying every day that the fair was open, to see the same horses go through the same games, at the same price. Because of the time I had spent on the bleachers watching the games of the so-called Bedouins, I lost my position on the Herald, and was driven back to San Francisco, where there were no Arab horses, and where, for this reason, I was able to hold a position on one of the newspapers.

At the close of the World's Fair, I saw by the press dispatches that the Arab horses which were to have been sent back to Syria, had been held by a mortgage in this country. and had been sold at an auction, but not until after nine had been burned to death in their 


\section{AN OREGON ARAB}

stalls. The remaining horses had been bought principally by people in New England.

Late in the fall of 1895, I came to New York City. One of the first letters I wrote was to Mr. Randolph Huntington, of Oyster Bay, Long Island, to inquire if he knew where the horses that had been at the World's Fair had gone. Mr. Huntington told me that he knew where one was, a gray mare, which was the best of the lot. I lost no time in seeing this mare, but it was several years before I found the rest of them. I was continually hunting for them and they were finally discovered in the possession of Mr. Peter B. Bradley, of Hingham, Massachusetts.

Mr. Bradley is an eminent horseman, who had accumulated, regardless of cost, some of our own trotters of the finest blood as well as thoroughbreds, hackneys and other types. Many of his Arab horses had died, but all that were left of the original lot Mr. Bradley owned. On my first visit to his place, I bought one of the bay stallions, and began to make a study of the Arab horse from close range. I bought some books on the Arab horse, and found that probably the Chicago Arabs were not what one would call desert horses, with the 


\section{MY QUEST OF 'THE ARAB HORSE}

exception of the fine gray mare, Nedjma, which Mrs. Ramsdell owned. The rest had been shipped from Damascus and were town Arabs. This made me all the more eager to do something myself. 


\section{CHAPTER II}

PROCURING THE IRADE AND THE START FOR THE DESERT

THERE had been but one thought uppermost in my mind ever since the liniment can days and that was, to go to the desert personally and in some way bring out Arab mares of unquestionable blood. I knew that to do that I should need a permit from the Sultan of Turkey. I also knew that while the Sultan had presented General Grant with two stallions, he had refused to let the General have any mares. It was commonly understood that foreign nations, which were continually seeking Arab blood for the Government studs, with difficulty obtained it.*

\footnotetext{
*In a letter his Excellency Chikeb Bey, the Turkish Embassador, at Washington, under date of December $27 \mathrm{th}, 1906$, in reply to a question from me, says: "I cannot tell exactly the date when the exportation of Arabian horses from the Ottoman Empire was forbidden, but if my memory serves me well, the first prohibition dates back thirty or thirty-five years."
} 


\section{MY QUES'T OF 'THE ARAB HORSE}

In the latter part of December, 1905, I asked President Roosevelt if he thought he could help me to get a permit from the Sultan of Turkey, as I had wanted to try and carry out plans which I had had in mind for several months, and I received the following letter from him on January 1st, 1906, enclosing another from the Secretary of State:

\section{The White House,}

\section{Washington, January 1, 1906.}

\section{My Dear Mr. Davenport:}

Anything you want I should like to do anyhow, and when it comes to dealing with Arabian horses I would take you up with double zeal. Is the enclosed letter from the Secretary of State all right? If not, make what changes you wish and I will have them put in. You can use this letter too with any of our representatives. With all good luck, faithfully yours,

(Signed) Theodore Roosevelt.

Mr. Homer Davenport,

The Evening Mail,

New York, N. Y.

With this letter I proceeded at once to Washington for an interview with His Ex[10] 


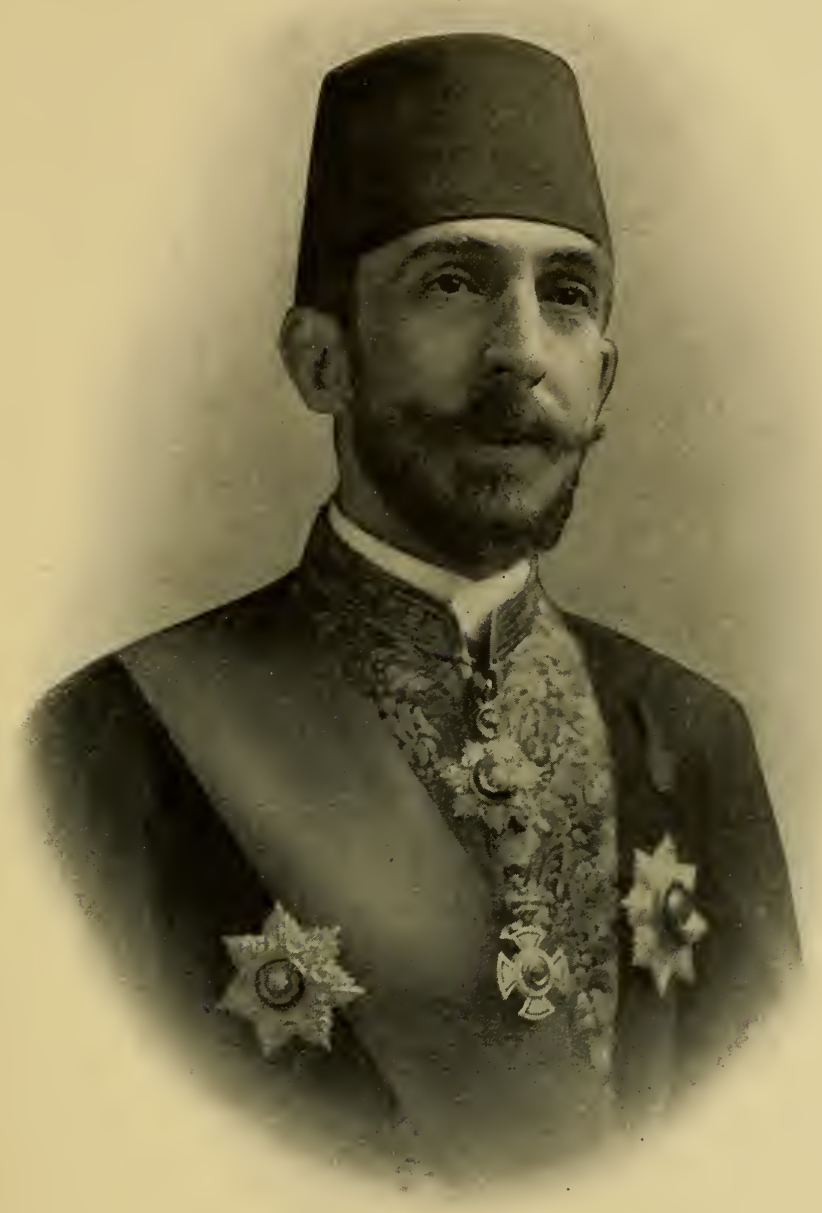

His Excellency Chikeb Bey, the Turkish Embassador, who procured for me the Iradé. 


\section{MY QUEST OF THE ARAB HORSE}

cellency Chikeb Bey, then the Turkish Ambassador, and after a very pleasant conversation with him (he fortunately is a horseman of the highest order) he assured me that while to get mares from the desert was almost impossible, still he would make an earnest appeal and would cable to Constantinople.

After a few days he received a cablegram in return which gave me the first ray of hope, for it inquired how many horses I wanted. There was some discussion then as to the number $I$ should ask for. After consideration I concluded that while six was a modest number, generally when you went beyond six you said twelve and that just to break the monotony of such a system I had best ask for six or eight. This was done and the Sultan left it just as I had put it, "six or eight," and to my utter astonishment, as well as the Ambassador's, granted the Iradé.**

\footnotetext{
*In a letter dated December 28, 1906, from Lady Ann Blunt, the most distinguished traveler and authoress of the Arabian Desert, commenting upon my success in procuring such an Iradé, the Lady has this to say: "There has always existed a prohibition to export horses from Turkish territory, but of late I believe it has been made more stringent, and the permission given to you must have been due to great judgment and skill on the part of the American Embassador. I doubt if at the present time any other diplomat would have a like success." I believe that the liberal permit was granted more through 


\section{PROCURING THE IRADE}

I had made all my plans to go alone to the desert, intending to proceed to Deyr, some $\mathbf{2 5 0}$ miles below Aleppo. A few days before I planned to start, a tall athletic young man with the snappiest eyes in New York came in to see me. This was John H. Thompson, Jr. We had met on two or three occasions before. When I told him I was going on the trip to the desert his eyes got even brighter and he said: "If I wouldn't be in the way I'd like mighty well to go on that trip with you."

When I told him that I would like very much to have him do so, he cut me short, and answered: "Let that stand until I come in tomorrow at 10 o'clock."

When he called the next day he said: "I'm ready to catch any boat. Are you?"

In the meantime I received a letter from $\mathrm{Mr}$. C. A. Moore, the president of the firm of Messrs. Manning, Maxwell \& Moore, telling me that his son, Arthur, was just as much of an Arab as I was; that he hadn't the slightest doubt that his son would dance at the mention of such a trip, but that he supposed it would

the influence of this distinguished Turkish official than through any efforts on the part of the American Embassador, though I am satisfied his efforts were of great help.

[13] 


\section{MY QUEST OF THE ARAB HORSE}

be out of the question to think of his son's joining me, as he was six feet four inches, weighed 245 pounds, and would, naturally, be in the way. I called up the office on the phone and the young man himself answered. His father hadn't spoken to him about the trip, but you could actually hear the interest accumulating in his voice. As I finished telling him what his father had written me, he said, "All right, we'll let it go at that; just count me in." I asked him when he'd be ready, and he said: "I'm ready now; I'll be up to see you in five minutes."

I heard his telephone receiver drop off the table and smash on the floor, and I came to the conclusion that he'd rung off, as I failed to get any more communication. And that's how Moore and Thompson came to be on the trip. You'll hear more about them later.

So, with a week's preparation, we sailed on the French line, July the 5th, 1906, for Havre, armed with powerful rifles, good letters of credit, and a few other lesser necessities of life in the desert. Before I left home I had in my stables all the horses that remained of the Chicago importation, except the gray mare, and one of her daughters that was owned 


\section{PROCURING 'THE IRADE}

at Newberg; but of her family I had two of her sons, one daughter and a grandson. So I had at last overtaken the horses, and the descendants of the horses, that I had seen slipping so gracefully on the pavements of Chicago. The passenger list was a very big one on the French liner, but, when the passengers went ashore in France, everybody who had been on board the boat, even to the eaptain, was fairly well informed on Arabian horses.

'The two young men who were with me were as proud of the Irade that I carried from his Imperial Majesty, the Sultan, apparently, as I was myself, and already it began to show the wear and tear of much handling.

We reached Constantinople on a train they called "The Limited," on July 19th, in the forenoon, and after the usual formalities over passports, went to the hotel. 'The American Embassy was almost next door to the hotel, and at the Lmbassy our first real excitement came. When I arrived, 'Thompson and Moore having preceded me, $\mathrm{Mr}$. Alexander Gargiulo, the first Dragoman, was talking Arab horse with my companions and they had told him that I had an Irade from the Sultan permitting me to export six or eight mares. 'This he thought 
ligation Intoriale.

is e Tirrquice

$1 \operatorname{kg}^{2} 10451$

भ̊tashimitutur.

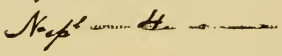

b. June Ht.

-light.

Sir.

Hon answer to your request addressed

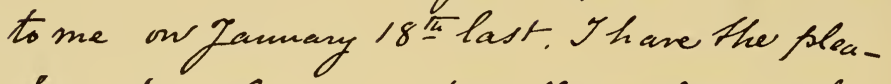
sure to inform you that $F$ ain advised by the Department of Foreign toffars that an Irade of His Imperial Majesty the Sultan, my August Master, has been us sued authorizing you to export dix or eight mares which you desire to purchase in Syria though your agent in Beyrouth

The necessary instructions to this effect have been gwen to the Department of the Interior and to the General Adnnimistration of the Induct Faxes

Recept hor, the assurance of my distinguished consideration

break

Les Homer Davoupost

The Evening Lace

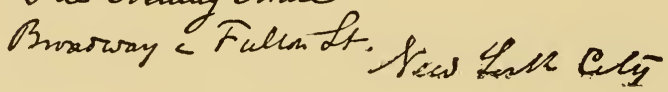




\section{PROCURING 'THE IRADE}

was impossible. So when I came in, and they asked me if I had the Irade with me, I took it from my pocket with some pride. Then came the usual fall. After Gargiulo had read it, he said it meant nothing; that he was afraid we had come a long journey for our health and into a poor country. He declared the "Irade" was simply a letter from the Ambassador at Washington, who could not write Irades. $\mathrm{He}$ added that during his forty years at the Embassy he had never heard of such a permit being granted to a Government, not to speak of an individual; he hoped that it was official, and said he would take the paper to the Palace and find out its authenticity.

Of course you can see what my sleep was that night. I had been in bed five minutes, perhaps, when my first dream was that I had met Mr. Gargiulo the next morning; that he had come to me as politely as possible and told me that the Sultan had no remembrance of any such correspondence; that he was indeed very sorry that I had been misled in coming so far from home at such an awkward time of the year. The next dream was similar, and so, after an awful night, I was up at daylight, peevish.

However, on meeting Mr. Gargiulo at about 


\section{MY QUES'T OF 'THE ARAB HORSE}

10 o'clock the following morning, he drew from his inside pocket, carefully, all the time smiling more and more broadly, my Irade, with official attachments pinned to it and with the added information from the Sultan, that, on this occasion, I could export with the mares what stallions I chose to purchase.

Things were different then; the dogs in the street looked a little better to us, and we figured out that Constantinople would not be such a bad place if they spent five or six years trying to clean the streets. We were jubilant; we went to see a polo match, saw the first Arab polo horses, and heard evidence from an English naval officer that to play polo nowadays, and play it right, one should be mounted on an Arab.

We were restless to get on our journey. The Sultan indeed had sent word to us from the Palace that it would be impossible, owing to the heat, to go to Aleppo and the desert at that time of the year, but we smiled, and sent word back with the royal messenger, that we were not on a pleasure trip, but on business only. 


\section{CHAPTER III}

THE SULTAN'S STABLES

Avxious as we were to get off to the desert there were enough things in Constantinople to keep us interested for several days, and chief among them were the Selamlik, the only time in those days when the outsider could get a glimpse of His Imperial Majesty and a visit to the royal stables. Of the Selamlik I shall tell at length in another chapter, for it deserves a chapter to itself. At the time we were in Constantinople it was not entirely easy for foreigners to witness the ceremony, but permission to visit the Imperial stud was easily obtained through Mr. Gargiulo. Mr. Gargiulo was with General Grant on the latter's visit to the Royal stables, when the Sultan offered him a stallion, which the General at that time refused. Later, when in France he saw what use France had made of the Arab blood, he wrote saying he would take the one offered. Mr. 


\section{MY QUEST OF THE ARAB HORSE}

Gargiulo told the Sultan how lonely a trip to America would be for one stallion and that two would travel better together. Accordingly the Sultan gave two. His Majesty picked out a gray and a black, and as they were being prepared for the trip, Mr. Gargiulo tried them, and found the black was not a good saddle horse. He had to think of some scheme by which an exchange could be made, but he knew he would have to have a good reason. Finally, as he went to the Master of Ceremonies, to thank him for the stallions for the General, he said: "But___"

"But, what?" said the Master of Ceremonies, with some heat- "you first ask for one, then for two, and when all this is granted, you say, "But- But what?"

"But-I have found from careful inspection of history," answered Gargiulo, "that no American ruler ever rode a black horse. Will not His Majesty send a horse of some other color for the black one?"

The Master of Ceremonies made note, and said His Majesty should be told.

The next day another horse had been chosen, a darker gray than the first one, which must have been "Linden-tree," as he was the darker [20] 


\section{'THE SUL'TAN'S S'TABLES}

of the two, and a better horse. Mr. Gargiulo said that as far as breed was concerned, no one knew their blood, they were just presents to the Sultan, and presents from the Sultan to General Grant, of no known blood, and were supposed to be pure Arabs. I told this distinguished old gentleman that "Linden-tree" was much written of in America as a barb, when he laughed heartily, adding: "No barbs were ever in the Sultan's stable, as he does not like the people, much less the horses."

The Sultan's stables are long, low buildings, with a row of wide stalls on each side of a passageway down the centre. They are very plain and the horses stand on the bare cement floor during the day, which is very bad for their feet. In the Arab barns we saw thirty-five bays and chestnuts, one black, and thirty-two grays and whites. Not more than twelve were pure white, and they had very dark skin around the eyes and nose. The superintendent of the stables did not know the breeding of the horses, but when I asked about a beautiful gray stallion, he said he was of Bagdad breed. This would be like saying he was a Philadelphia horse. A chestnut stallion that seemed to be the favorite, was called by the [21] 


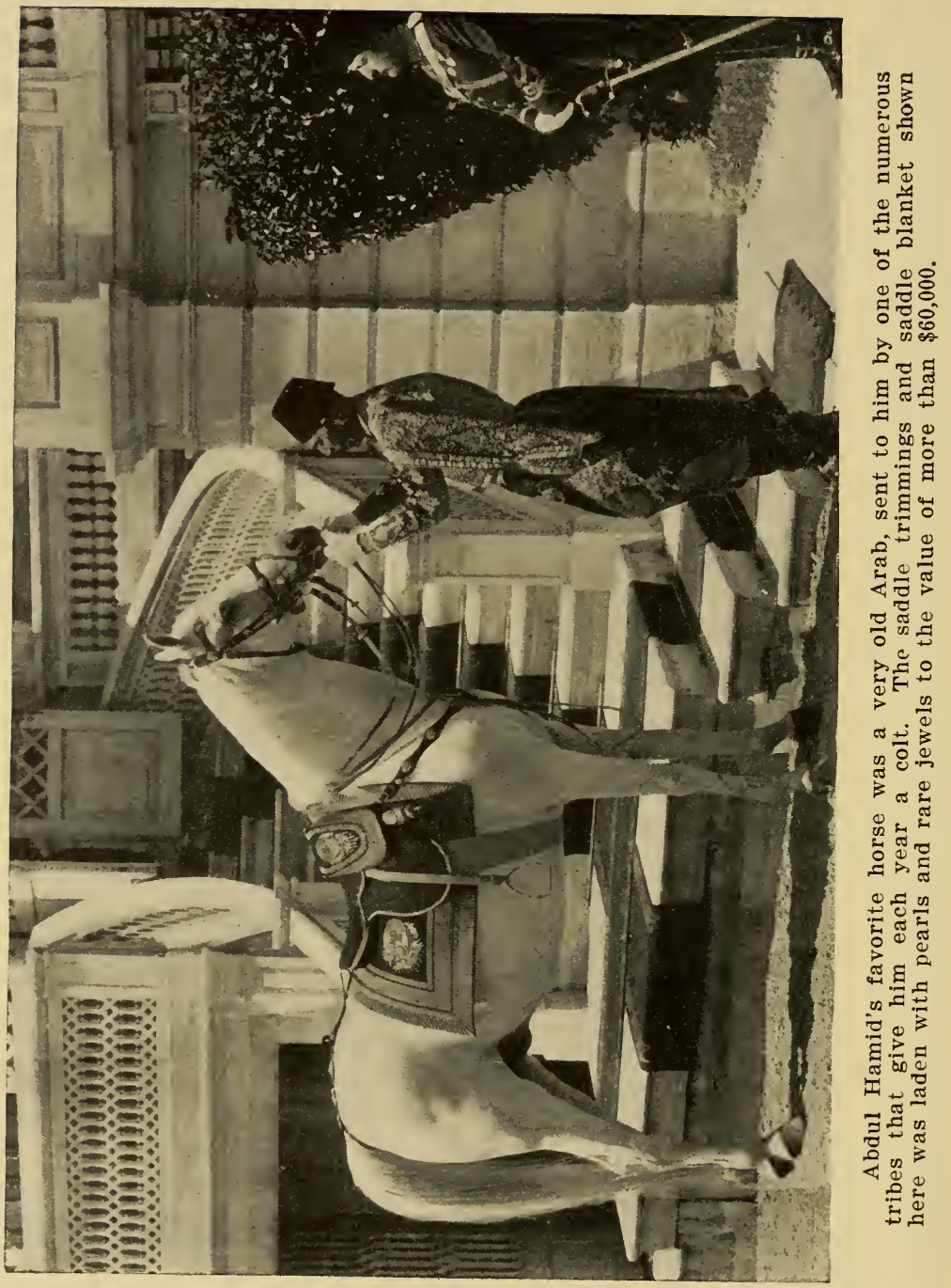




\section{THE SULTAN'S S'TABLES}

superintendent a "Nejd" breed. Now there is no "Nejd" breed; the people of Nejd buy their horses from the Anezeh, as Nejd is not a good horse country. I asked if he had any Seglawi Jedrans (the favorite breed of the desert), and he brought four stallions, bays, which he said were Seglawi Jedrans. But when I suggested that a chestnut, a fine specimen, looked like my own Mannakey, which is a Hamdani Simri, the man in charge hearing the words "Hamdani Simri," immediately nodded, and said the horse was a Hamdani. This made me think that he simply was trying to please me. The Sultan's horses are of good blood, though perhaps they are not all that would please the Bedouin. They are kept badly and without exercise. If they were other than the Arabs they would have lost all semblance to horses, but the Arab can cavort round even with his flanks full of fat when another horse would completely collapse.

As the horses were brought out in front of the main stables they were ridden by one of the most expert men I have ever seen in the saddle. From the point of style he was flawless. His hands were almost under him in his seat, any antics or play of the horses did not disturb 


\section{MY QUEST OF THE ARAB HORSE}

him in the least, and his command of the horse was perfect. Not many of the horses had jibbahs, or full foreheads, so esteemed by the Bedouin desert tribes. They were ridden in a circle over a pile of loose stones about the size of hen's eggs.

Yet over these rolling rocks they galloped and pranced, changing gaits as easily as an auto will shift its gear. We all commented on the fact that there never was a misstep, or a stumble, or a bumping of ankles. A bay horse with a peculiar blazed face and feet, eighteen years old, was as nimble as any colt. Their lack of exercise was plain from their stuffy flanks, but their action was beautiful. In the stall they were tied from each side, and from the middle of the nose-band, and one, a white stallion, was fastened by the front pastern. To get exercise most of them had pawed holes in the concrete floor. All in all they were a fine lot of horses, but poorly kept, to say the least.

The Sultan, himself, is a horseman, and perhaps knows the breeding of every animal in his stables. And he being a horseman, I would dare make a suggestion to him, as a Westerner to an Easterner.

The horses in the Turkish Empire show a [24] 


\section{THE SULTAN'S STABLES}

lack of good stock. They are deplorably in need of new blood. I would suggest to His Majesty that he send his fine stallions each spring all through the Empire and breed them to the really good mares which are to be found in all parts of the country. The French Government has followed this plan with excellent results. The fee should be small, of course. In France it is only $\$ 3.00$ and this comparatively small sum enables the poorest peasant to secure the service of the best stallions the Government owns.

If this were done I venture to predict that in ten years the majority of horses in the Turkish Empire would be good instead of what they are now-bad.

Germany and Russia as well as France have done this very thing, not only with their own horses, but with the very few which they have been able to import from Turkey. The result has been almost amazing.

Then when one sees such a large number of finely bred stallions going to waste in stables where they are not even exercised, a suggestion like the one I have made comes naturally to one's mind.

The Sultan has, of late years, established [25] 


\section{MY QUEST OF THE ARAB HORSE}

some farms, where he takes pleasure in breeding from the finest animals he has in his stables, and where he could start the foundation of what would be immensely appreciated by his people.

It must be remembered that when we were in Constantinople the old régime was at its best-or its worst. Perhaps among the reforms which Abdul Hamid has promised since the "revolution" to his subjects, the improvement of the breed of horses will some day be numbered. 


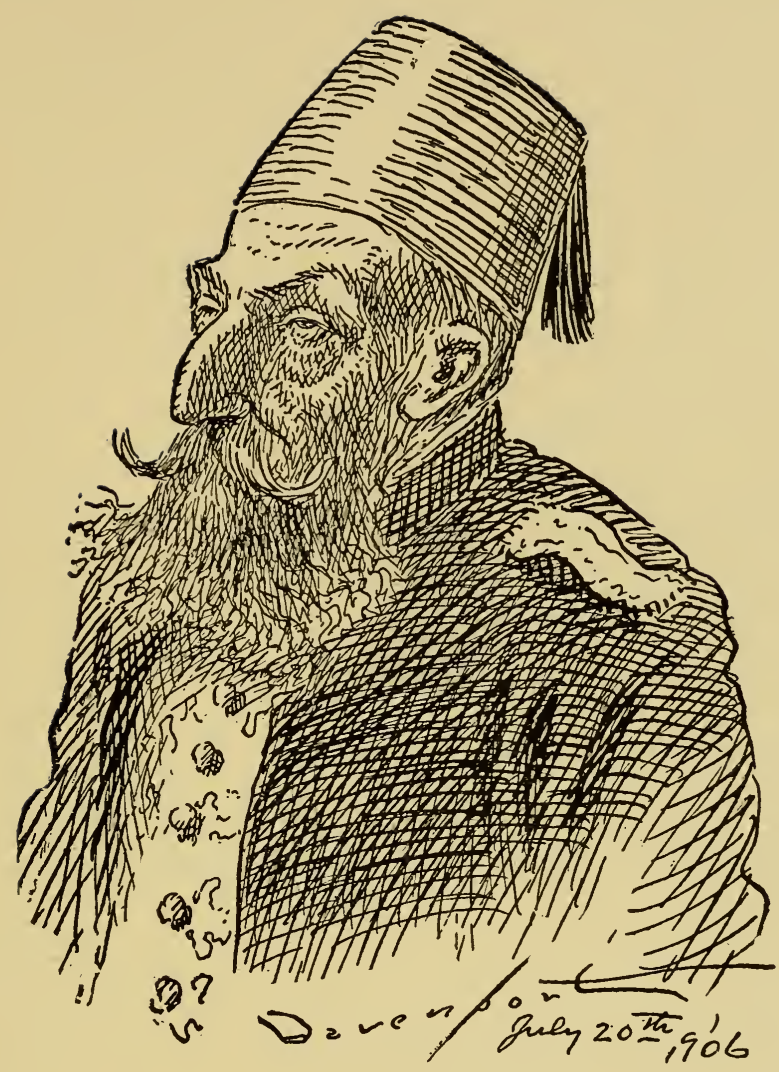

Abdul Hamid, His Imperial Majesty the Sultan of Turkey. Up to this time this was the first sketch ever made of the Sultan, and might have cost a lot of trouble, to say nothing of human suffering, as high Turkish officials that had helped me procure the Irade were in danger of being put in exile owing to this sketch, and had it not been for the Hon. J. B. Jackson, American Consul at Alexandretta, Turkish spies would have discovered it and my horses and mares been confiscated. As it was, the picture was smuggled onto the ship in a bale of hay. I dare say it's a strong caricature of the Sultan instead of a character study, though that matters little to him now. 


\section{CHAPTER IV}

THE SULTAN OF TURKEY

At the time we were in Constantinople, to see the Sultan was an event. The only possible opportunity for the public (the very limited public) to get a view of him was at the Selamlik. This was a sort of religious parade, accomplished every Friday, when His Majesty drove a few yards out of his palace grounds and down a hill to a mosque for religious worship.

'The custom of centuries, the Mohammedan religious law, even, had decreed that on every Friday the successor of the true prophet should make his devotions at the Mosque of St. Sophia. And for centuries the Sultans of Turkey obeyed the law and custom.

Every Friday saw them proceeding in state to the ancient church erected by Constantine when the cross was above the crescent on the 


\section{THE SULTAN OF TURKEY}

Golden Horn, and there promising God and His prophet to maintain the faith.

Even Abdul Aziz, in whose reign the eternal "Eastern Question" first began to ask emphatically for an answer, and who was murdered in 1876, did this thing; even Abdul Murad, who was "removed" after two months of nominal rule, did it; and even Abdul Hamid II followed their example for many years. 'Then came more troublous times. His Majesty immured himself in the Yildiz Kiosk and the risits to St. Sophia became less frequent. Indeed, they ceased altogether. For, remember-the Yildiz palace is on the Bosphorus above Pera; and Pera is above Galata; and between Galata and Stamboul there is a long and treacherous bridge of boats, and between the bridge of boats and St. Sophia there are many narrow streets to traverse. From any window of the houses that line these narrow streets, a bullet might be fired or a bomb might be dropped and who the wiser, though the sidewalks be lined with troops?

Once in a long time Abdul Hamid made the trip from the Yildiz Kiosk to Stamboul down the Bosphorus in a boat. But Bosphorus boats, as many Sultans of Turkey know, are 


\section{MY QUEST OF THE ARAB HORSE}

dangerous affairs, so even this was finally abandoned. Worship was confined to the Mosque near the Yildiz Kiosk. Even in these narrow precincts His Majesty was not safe, as the bomb thrown at him a few years ago bears witness.

It was natural, therefore, that the attendance at the Selamlik was carefully scrutinized and that one's credentials had to be thoroughly looked into before a permit to witness the ceremony could be obtained. Generally the getting of the permit is a matter of four weeks or so, but we had no time to spare and so were prepared for the ceremony on short notice.

It required real activity on the part of the Embassy to get us three to the post at the right time and it was at 11 o'clock Friday morning, July 20, 1906, before we knew the "one best bet." Our appearance was a shock to the dignified foreign consuls and ambassadors. For some reason or other, they did not think we were dressed exactly right. Moore wore his own trousers, with a borrowed frock coat which was a little tight for that kind of a day, and a borrowed plug hat (that's the only name to call it) which was two sizes too small. It is strange, but true, that some other fellow's

[30 ] 


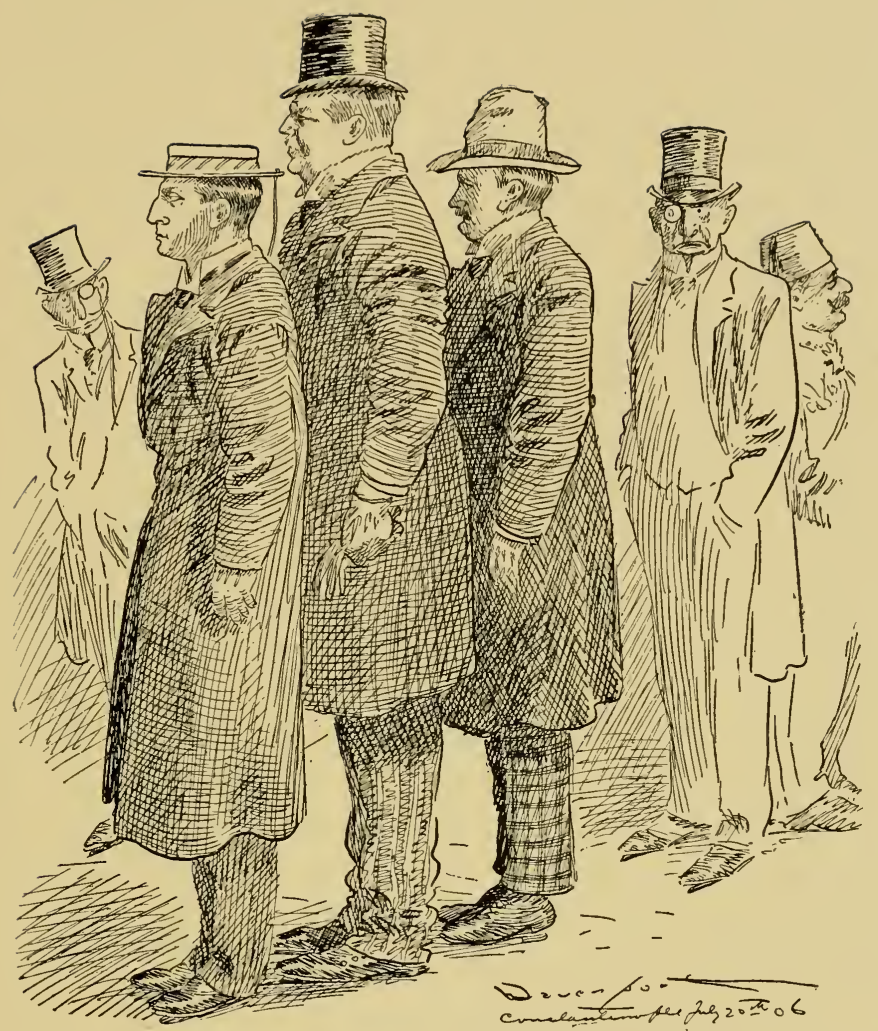

It was a rare treat for the diplomats when we lined up for admission to the palace. 


\section{MY QUEST OF THE ARAB HORSE}

hat never looks quite right on you, especially if it's a size and a half too small. Moore handled his hat as a farmer does the parlor lamp. He dropped it once, and it fell out of the carriage the same number of times. He didn't wear it, but he tried to balance it on his head as a carrier would carry a jug of water. Thompson did not have a frock coat, but he had a raincoat which he said he could button so that no one could tell it from a frock. This, with ordinary trousers, and a straw hat anchored by a clothesline to his toughest buttonhole, completed his outer raiment. As for myself, I had a frock coat, with trousers of another suit, and a plain slouch white hat that looked well (I thought, in New York), but which showed the effects of the trip on the Oriental Limited from Paris. It was all right to turn water, but I saw that the foreign diplomats noticed the general outfit, which, in a baseball term, was not what one might call "team work."

We were hurried into two carriages to the scene of action, with officers wrapped in gold braid distributed among us, which gave to the trip a military atmosphere.

The feeble dogs dragged themselves out of [32] 


\section{THE SULTAN OF TURKEY}

the way just as the wheels grazed their hind quarters, as we rode through the hot, foul streets. Donkies, bearing heavy burdens, were yelled at by our driver; we passed line after line of soldiers, who all saluted; we climbed hills, where the cobblestones were very rough; we saw troops; we passed an officer mounted on a horse that showed much Arab blood. Finally we came to outposts through which few passed, but we drove on and on, passing line after line of strict guards. As we passed along, the fences and gates were more heavily plated with gold, and at last we arrived at the wing of the Palace facing the street. In the reception room, properly dressed diplomats stood as stiff as iron statuary on old-fashioned country estates. We nudged ourselves with elbows as we saw people recognize that this, that, or the other, of our garb, was borrowed. We felt that the whole Turkish Army, which had been drawn up in review outside the Palace, knew it. Still, in our awkward manner, we thought that the army, at least, might think we were diplomats from some countries that they had not heard of.

As we were being presented to high Turkish officials, Moore nearly dropped the bor- 


\section{MY QUEST OF THE ARAB HORSE}

rowed silk hat again, and an officer, who could speak a little English, asked Thompson if he did not find it a warm day for an overcoat; so discovered, he took it off. We laid our hats

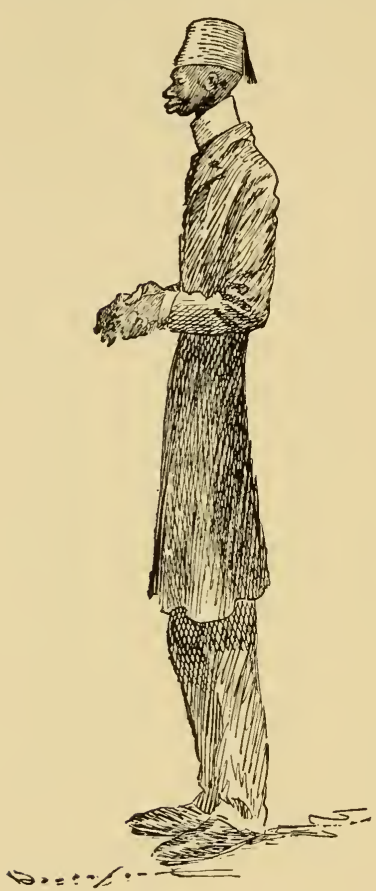

A Royal Eunuch. on the big table, among the other plug hats, and some in the room smiled again.

From the balcony window we watched battalion after battalion arrive and form a mile in each direction; all along the route of the short parade soldiers stood with bayonets in their rifles. Band after band came, that reminded me of the Silverton band, in Oregon. One was actually playing the same march we used to play in Silverton-"Belgrade."

Troops had been forming for more than an hour. We noticed that there was a great difference between them and our soldiers, and at first we could not think what the difference 


\section{THE SULTAN OF TURKEY}

was, but eventually we struck it. These soldiers never smile. They look as if they were going into immediate battle. There was no expression of good fellowship; they seemed tired, and not one recognized, in any way, the comrade by his side. When they saluted the generals, or some high state official, the action was as automatic as that of a wooden soldier.

And now the ceremony is on. The Sultan's Master of Ceremonies comes and we are presented. He is all smiles, and at a distance, from the motion of his hands, you think he is washing them. He explains that much as the Sultan might have wished, an audience with us is impossible, but that he will be glad to arrange it for a later date. Through him, I thank the Sultan for the honor of the Irade, which had brought me to Constantinople.

Presently a carriage comes up the little steep hill, with guards at the side. In this closed carriage we see two women with veils over their heads; beside them are sitting two girls, perhaps fifteen years of age or less. They peer at the visitors on the veranda, and in at the windows of the Palace; they seem curious to know what things look like outside of the three great walls. It is whispered that 


\section{MY QUEST OF THE ARAB HORSE}

they are princesses, daughters of the Sultan, and that the others are women of the Harem. Back of this carriage walk six ill-shaped, gaunt, long-legged black beings; they look more like educated apes than species of men. Their hands are awkward, and their feet are long and vulgarly flat. All they do is to smile and follow the carriage, like coach dogs. Their long black frock coats even have a disagreeable swing; they are Eunuchs, and when they speak it is in a high tenor voice, not at all musical.

It is getting close to the hour of the ceremony and some foreign officer in the Palace complains that the Sultan is late. A double line of distinguished men, nearly covered with braid and medals, and swords, marches down and forms a circle around where the Imperial carriage will be drawn up. These men are the guards of the household. Then three stately men, old men, march silently by. They are field marshals. Two small children appear on the marble steps where the Sultan will soon appear. They are the Sultan's children, boys aged about twelve and eight. Their uniforms are very heavy, but they bear themselves easily and naturally. Generals bow to them and 


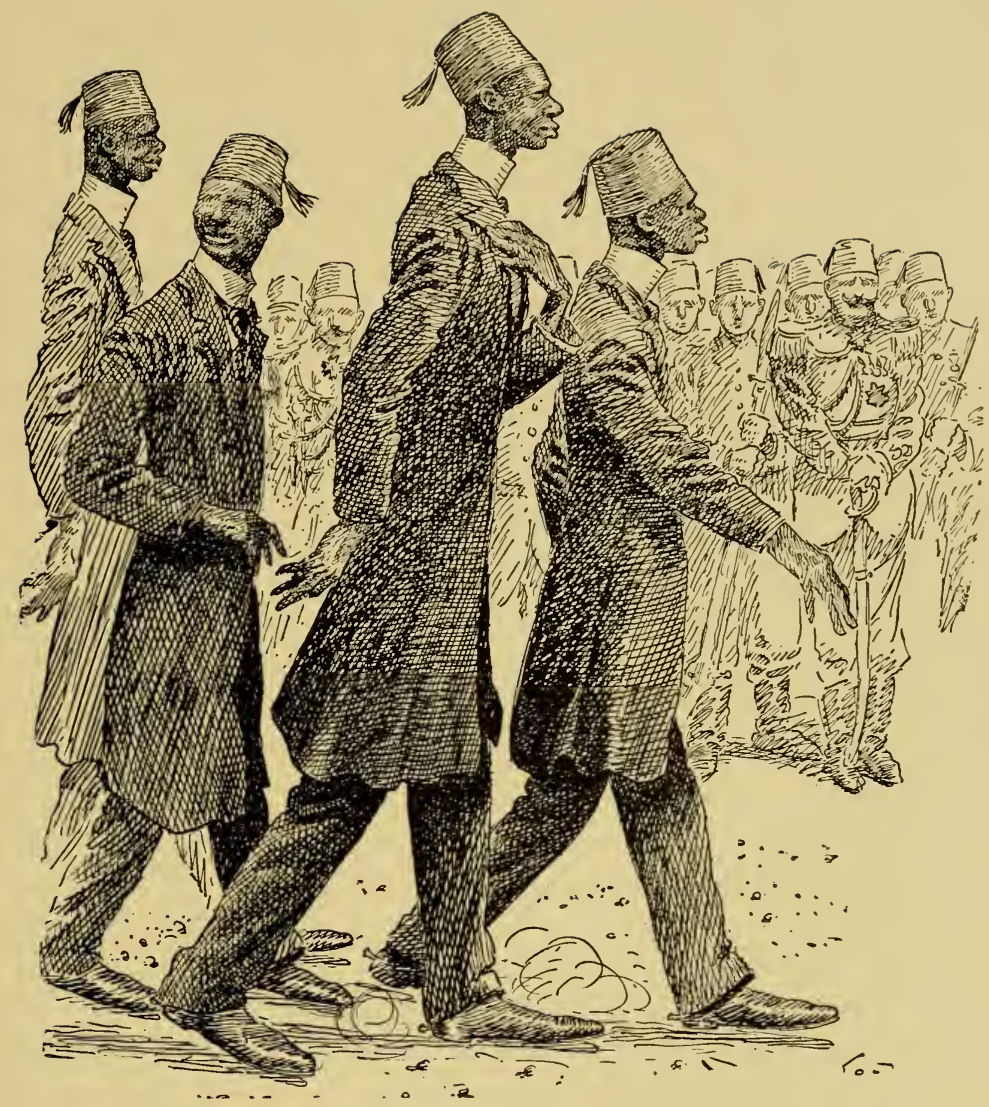

Royal Eunuchs following the carriages of the Princesses in the parade. 


\section{MY QUEST OF THE ARAB HORSE}

their tiny spurs glisten from their boots, although no stick horses are in sight.

While all is still, a trumpet makes a loud, long sound and swords and rifles, like one big click from a tremendous clock, are brought up to present arms; and then we hear from up near the top of the Mosque a priest yelling in a monotone, something that suggests a song, or prayer of some wild desert tribe. Thousands of soldiers yell at the same instant, as if by some automatic process, the same words. The sound makes you shudder with its wild melody.

An open carriage comes through the great gates, which sparkle like gold as they are swung open. Surrounding the carriage are guards, with drawn swords and tightly clenched fists. Hitched to the carriage are two fine bay horses, with docked tails. Their coats are as golden as their harness; they prance, they need exercise. There, saluting in that automatic way, rides the Sultan. In the seat facing him is a ponderous man; I don't really see him. I just see the reflections and high lights. I know that his local color is white and red and gold. They tell us that this large glittering object is the Minister of War. At 


\section{THE SULTAN OF TURKEY}

any late he seems to wear everything the army has ever captured. But I was there to see the Sultan-and to draw him!

Can you imagine my feelings? Here was a man, not twenty-five feet from me, whose features most of the world did not know and wanted to see; one of the great rulers of the earth who had never posed for a picture-and I did not dare pull a sketching pad from my pocket!

I was afraid my eyes would not register. Suppose a fly had flown into them for just that brief moment? Suppose I had sneezed? It would have been rough handling, and it would have meant expulsion from the country if I had drawn a pad from my pocket, as detectives and spies stood behind us watching our hands. Worst of all, I was afraid that if I did make an attempt to sketch I would have my Irade taken away. So it may be plain why I did not notice the Minister of Wär, or whoever it was in the carriage with the Sultan. I did not even notice the beautiful Arabian stallions which were led just back of his carriage.

But my eyes did work and they did register even under such a strain. I saw the Sultan's features well, and they were mine; so much so

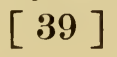




\section{MY QUEST OF THE ARAB HORSE}

that on his return from the Mosque, driving himself behind two white Arab stallions, it seemed that we were old friends.

The Sultan is, after all, just a man; a frail, elderly man, enjoying, I should say, the best possible life under such conditions. Unconsciously he rather shrank from the gaze of so many hungry eyes, though he bore a kindly expression mingled with a certain degree of fear. $\mathrm{He}$ looked like a combination of the late Nelson Dingley, of Maine, and Mr. Nathan Strauss, of New York. I can say this with all due respect to the three concerned. The Sultan's forehead is a thoughtful one, although his fez prevented me from seeing how high it was. His eyes and eyebrows, while showing the strain under which he lives, also show that he is a kind father, and would, if permitted, be a kindly home man. His face is thin and frail; his beard is carelessly kept. One of his eyebrows strays back of his eyebrow bone, almost into his temple. As his carriage arrived at the Mosque, the generals fairly bowed to the ground. He climbed out as most men of sixty-four years would. His children greeted him, and he turned to admire the smaller one.

[40] 


\section{THE SULTAN OF TURKEY}

Standing, he is below the average in stature, slightly bent on the shoulders.

He was fatherly to his children, turning after he had gotten up three steps to come back one step and greet them again. I thought when I saw this that no matter what crimes had been charged to him, his expressionless soldiers, his army and its leaders were possibly more to blame than he.

If you ever saw Nelson Dingley walking up and down the aisle of the House of Congress, even through the worry and stress of the Dingley Tariff Bill, you saw in him a kindness so stamped that it showed through the slight snarl of expression brought on by overwork and bad light. So when the Sultan turned to help his little tots, who were playing generals, he was Nelson Dingley turning, though tired, to listen to the jest of his famous colleague, Tom Reed.

Consider the handicap of being born to be a Sultan, or a Czar, or a King; of being deprived of the opportunity of meeting the common people. Think of not being able to enjoy a fireside chat with your family, or of the influence of a wife. Think of being brought up to know the earth only by its maps and not its dirt and 


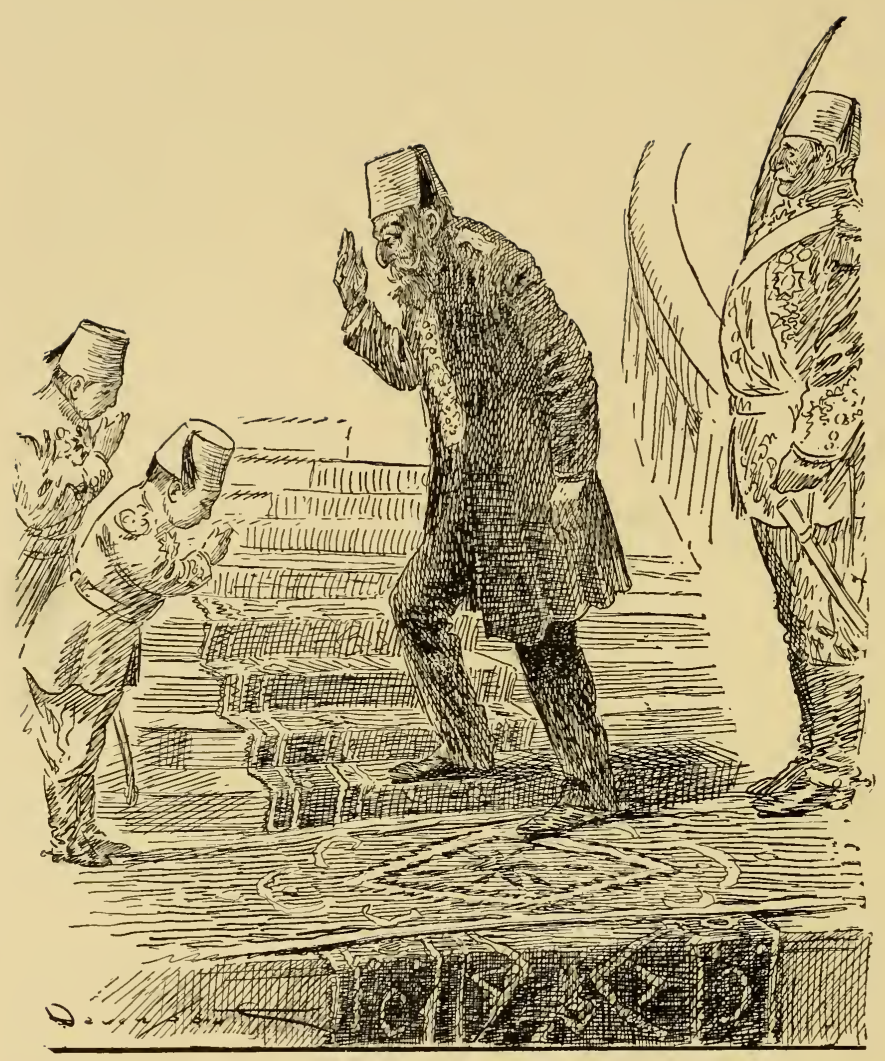

Abdul Hamid is greeted by two of his sons at the steps leading to the Mosque. 


\section{THE SUL'TAN OF 'TURKEY}

soil; its countries by the uniforms of their armies and not their peoples; to know just a few men and then only through layer after layer of cold, gold braid. Think of the ruler of a nation who has never had the opportunity of knowing personally the big, broad-minded, natural man or woman, and then you will not wonder at him for not having a fair understanding what the world is really for. The holder of such a throne only knows what the doorkeeper to the throne tells him, and these keepers naturally tell him what is best for them and for the people nearest them. The lessons that are in the lives of other men are kept from him. He does not even know how they lived, or when they died. I have heard stories of the Sultan's cruelty, and most of them I do not believe. If he is cruel, his heart and face do not show it.

So I think the Turkish system is more to blame for the Sultan's ill reputation than the Sultan himself. He has been forced to become suspicious. He has been able to trust no one and he has achieved the reputation of not being trustworthy himself. This digression will explain in part the impression reduced to drawing of my view of the Sultan. 


\section{MY QUEST OF THE ARAB HORSE}

A greater part of an hour must have passed, while we could hear singing in the Mosque, and as the Sultan came out, he kissed the hands of a general of the Royal Guard and then half knelt before him. The fine rug was re-spread on the marble landing and a carriage was drawn up that had previously gone to the Mosque empty. It was a top-phaeton, drawn by two white Arabian stallions, with long, artificial like looking tails. They pranced, but were well broken and behaved. Two grooms in golden robes stood at their heads. There was a pause and then everybody opened their mouths and yelled. Guards on the marble stairway began to bow, some knelt, and slowly this frail, elderly man, with black coat and trousers, with a golden vest that buttoned up under his beard, came in sight. His fez was red, and the only other color was in the small plain bands of gold on each shoulder. He touched his lips and forehead with his half-closed hand and with the same mechanical stiffness. $\mathrm{He}$ tarried on the stairway, looked across over the tired looking city, turned half round, and saw a thousand cavalry mounted on dapple-gray horses, a thousand on black horses, a thousand [44 ] 


\section{THE SULTAN OF TURKEY}

on bays, an equal number on chestnuts, all holding aloft small standards.

Again came the yell that echoed over in Asia. One of the princes joined his father, who climbed into the doctor-like phaeton as the top was lowered, and took the lines where they had been carefully left, properly tucked between the white whip and the dashboard. The grooms left the stallions' heads and the procession started back. The fine white Arabs, rolling in fat, started to play, and the Sultan popped the whip on the loins, with the same peculiar jerk that common cabmen here use. He then held the reins and whip in his left hand, and saluted, when the great army, so statue-like and cold, fairly knelt to the ground. Back of his carriage pranced a black Arab stallion, and back of him a fine bay one, with white feet and a star in his forehead, and back of them two dapple grays. They were saddled and bridled in rich gold trimmings, looking fit for the Minister of War. But they were not for the Minister of War. They were there in case the kindly appearing old gentleman might want to ride. He did not care to do so that particular day. He preferred to drive and as he passed up through the big, gol- 


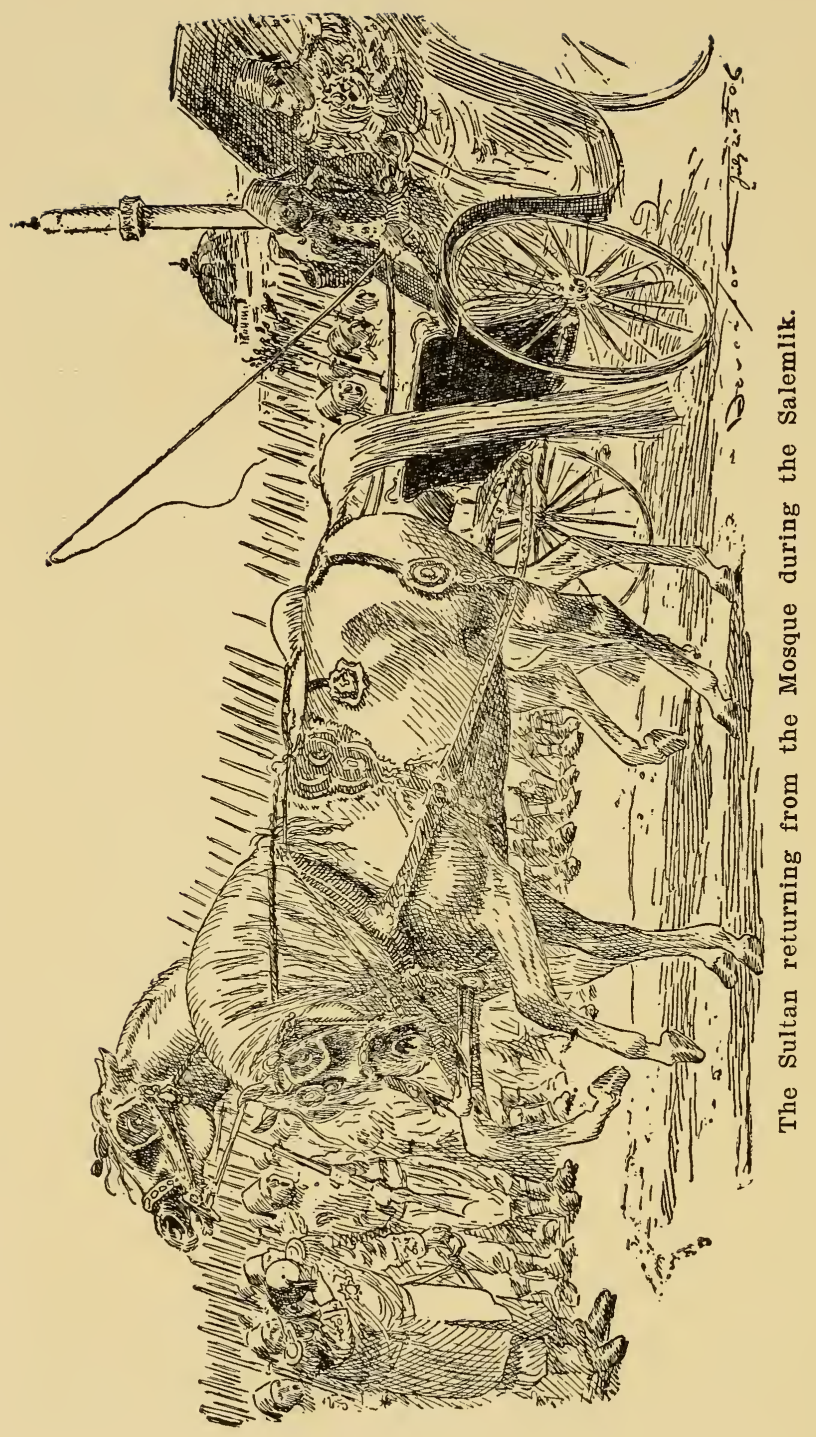




\section{THE SULTAN OF TURKEY}

den gates, his personality was that of an old man who might be knitting. He led you to believe that you had actually known him well, a long, long time.

Our effort was to get out of the Palace as quickly as possible and draw the picture which I had in mind. It would be necessary for us to get some miles away, as we were already looked upon by the Turkish spies as men sent by the President of the United States to investigate Armenian trouble. But after twenty minutes ride from the Palace, Moore suggested that I should not risk going further. He said I ought to put down the impression of this remarkable old gentleman before anything faded from my memory. So, guarded by two big stalwart young men, I made a picture, which pleased us beyond expression. I had got at something which made the drawing one of the man himself, not an idealised Sultan. It soon became our greatest care to know how to protect it. Under much persuasion we showed it to an intimate friend of the Sultan in Constantinople; a man who had known him for forty years. After I had showed it to him, and he kept looking at it, I began to get nervous. It dawned on me all 


\section{MY QUEST OF THE ARAB HORSE}

at once that if he said that the picture was not a good likeness, then my confidence in it as a likeness would be destroyed. But soon he closed the sketch book and handed it to me with a whisper: "It is the only picture of him ever made. If it is ever known that you have it your visit to the Ottoman Empire will be a sad one." He implored us not to write to America about it, but to keep it always in an inside pocket tightly buttoned.

We thought we had carried out these instructions. In Aleppo it was shown to only one man, and out in the desert only Akmut Iafez and Hashem Bey saw it. Yet when we approached Alexandretta, on the way back, an American came three hours ride into the mountains to meet us and tell us that the Turkish spies in Alexandretta knew, or thought they knew, that I had a picture of the Sultan with me. He told us that if this picture was discovered all my horses and mares would be confiscated, that the Irade would be taken away and that the trip would count for nothing. So we put the sketch-book containing the Sultan's picture, in the middle of a bale of hay, which was secretly marked. Then we took two Arab soldiers into our confidence and told them 


\section{THE SULTAN OF TURKEY}

to keep a secret watch out on that particular bale of hay. When we arrived in Alexandretta, the spy, who had seized our guns on our way in, hunted through everything, but failed to find what he was after.

I had collapsed twice that morning with the intense heat, and went out with the first lighter of horses to the steamer. No greater sigh of relief was ever heaved than when I saw coming on the last lighter to our boat, as she lay anchored in the Mediterranean, the last of the horses and mares, and with them a bale of hay, that meant more than all the other bales of hay I had ever seen. 


\section{CHAPTER V}

FROM CONSTANTINOPLE TO ANTIOCH

Having seen the Sultan and having the Irade confirmed there was little else to be done in Constantinople. We were ready and even were anxious to start forward to accomplish the real end of the trip. From the beginning it had been my intention to go to El Deyr on the Euphrates and there purchase horses which I might be assured came from the Anezeh themselves. I was under the impression at that time that the Anezeh, not often coming so far north as El Deyr, would only be found in the neighborhood of Palmyra, that "Tadmor in the Wilderness" which is as old as Solomon.

In Constantinople my views about going to Deyr, however, were somewhat modified, although my plans were not entirely changed, as will be told further on, until we reached Aleppo.

At the Pine Palace Hotel in Constantinople

[50] 
we met Mr. Forbes of the firm of MacAndrews $\&$ Forbes, the largest dealers in liquorice root in the world, which makes its exportations mainly through Alexandretta or Iskanderoon, as it is locally known. Mr. Forbes is intimately acquainted with the country around Aleppo and knows all about the desert beyond.

Mr. Forbes laughed at the idea of going to the Desert at that time of the year, and said that we ought to stay in Constantinople at least until January before making the attempt. He declared that we would be unable to stand the heat, even in Aleppo, and that because the Bedouin wars had been so many and frequent for five years, his firm had discontinued the shipping of liquorice from points near Deyr. We admitted that our knowledge such as it was, had been gained mainly from the books of Mr. Wilfred and Lady Anne Blunt, written thirty years before, but that we were prepared to go to Deyr if necessary.

Mr. Forbes still strongly advised against that plan, but gave us ample letters to his people at Alexandretta and Aleppo, and also cabled them that we were coming. Mr. Forbes owned an Arab horse in Smyrna with which he had won the Sultan's cup in a race, and had 


\section{MY QUEST OF THE ARAB HORSE}

been trying to get a horse he had heard of in Aleppo. This was a great brown stallion which had been recently presented to the Governor of Aleppo. The Italian Government had tried to buy him, but he was known as the "Pride of the Desert," and had been presented to the Governor by the combined Bedouin tribes.

Nothing, said Mr. Forbes, could persuade the Governor to sell him. He was beyond all value and price in the estimation of the Pasha. All this naturally aroused our great curiosity and interest and we were more eager than ever to be off, little thinking how well we were to become acquainted with the desert's pride and his owner.

The next day we left Constantinople for Alexandretta via Beyrout, Syria, a rather roundabout voyage of eleven days with numerous stops.

In Beyrout, through the kindly assistance of United States Consul Magelssen, we were enabled to employ as interpreter for our trip to the desert, Ameene S. Zeytoun, who had been in the employ of the American Government for a number of years, and who spoke English as well as he did Arabic. The further we went 


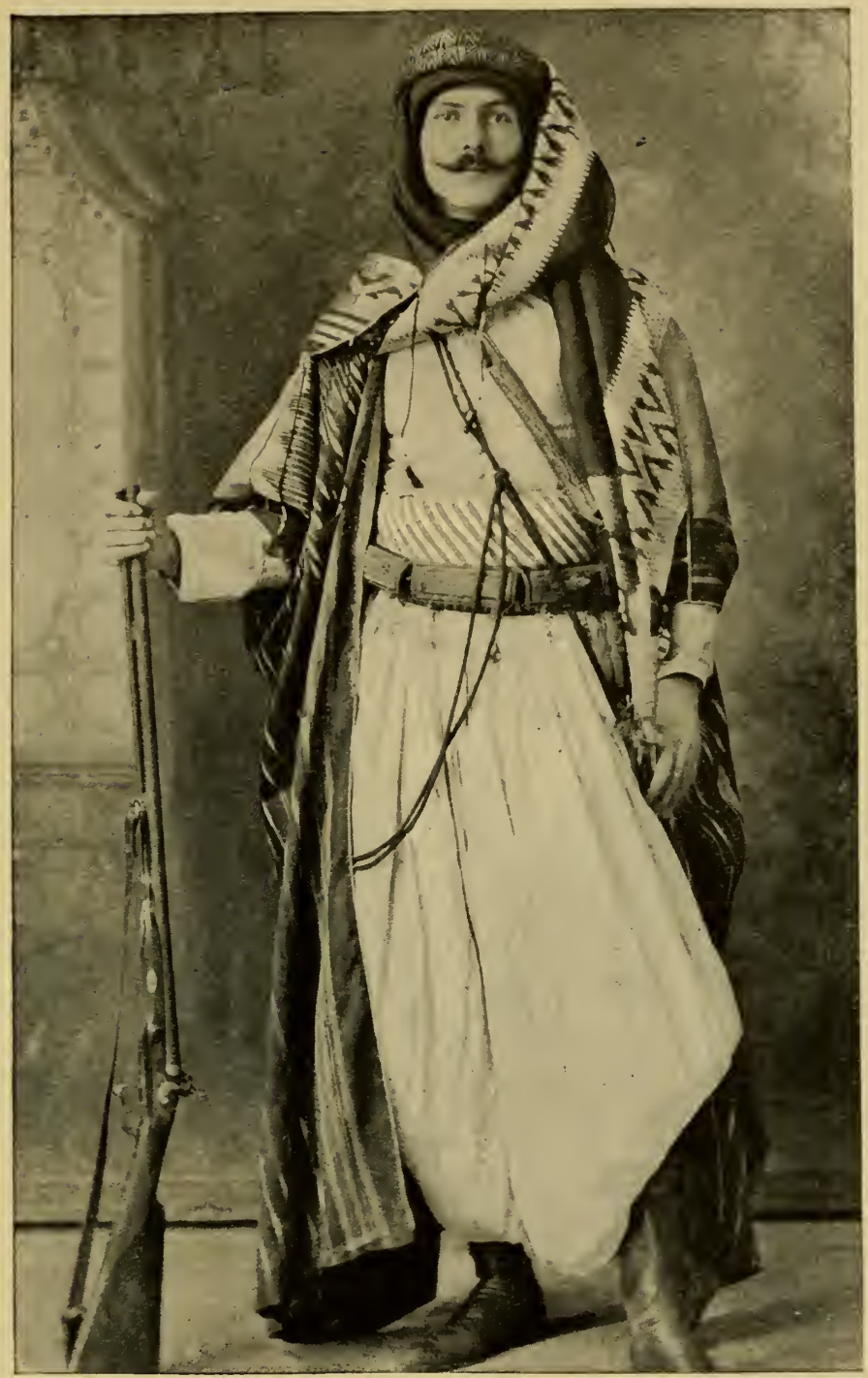

Ameen Zaytown of the American Consulate at Beyrout, who was my interpreter to the Anezeh. A more faithful and thoughtful young man I have never met. 


\section{IIY QUES'T OF THE ARAB HORSE}

the more we congratulated ourselves that we had been able to secure Mr. Zeytoun's services. He was of the greatest aid in smoothing out any difficulties which arose from our ignorance of the language or the customs of the people and was always diplomatic and courteous.

Nevertheless we were very glad to get away from Beyrout. We saw there the kind of "Arab" horse which could readily be sold to the stranger as the genuine breed, and we also encountered the crooked horse dealers of the East, who naturally swear to anything unless it be the truth. But we were spared from falling into their traps and it was daylight on August 2nd, when the noise of the anchor chain, as it rattled down, woke me up as we were lying off Alexandretta. I had been warned against Alexandretta by Chekib Bey, the Turkish Ambassador at Washington, as a dangerous place to stop in even for a night and further by Mr. Forbes, who said it was one of the most unhealthy places in the world, owing to the mosquitoes, and the fever which followed their bite. We soon had first class confirmation of these warnings.

Shortly after the anchor was dropped, two [54] 


\section{CONSTAN'TINOPLE 'TO AN'TIOCH}

Englishmen came aboard and asked for us. They were from the MacAndrews \& Forbes Liquorice Works. One, a Mr. Sneddon, was very sick of fever, and the other looked to be in a bad way. While I was producing a letter from Mr. Forbes Mr. Sneddon suddenly grew faint, and the other man apologized.

"That poor fellow is down with the fever again," he remarked, and as Sneddon lay down on the deck he added: "It will only be for a moment; he will be all right presently." Mr. Sneddon lay there groaning, but after a few moments he straightened up and read the letter. That's the way the fever takes you.

Then we went ashore and as soon as we landed we ran against the ignorant red-tape of the Turkish empire. All of our guns were seized, except a three-barrelled one and that was exempted because the officials thought that the third barrel (a rifle one), was the ramrod holder. We just had to have those guns, so after breakfast we went to the Custom House where the Governor of the town was closeted with the Collector of the Port. Both these officials had orders from Constantinople to pass our sporting rifles, but they had been advised, they said, that our firearms did not come within 


\section{MY QUEST OF THE ARAB HORSE}

that category because they could see no ramrods attached to them. It was futile to enter into any argument and we soon learned what the trouble was.

Al Hami Bey, a spy of the government, was the trouble. The Governor and the Collector were afraid of him. He had rumored about the town that we were gun manufacturers from America, and that our guns were only samples of what we were taking to the desert. We drank, it seems to me, as I look back on it, coffee by the gallon and smoked cigarettes by the dozens, but nothing came of these official hospitalities. We could not get our guns until further and more explicit instructions came from the Sublime Porte. That meant, apparently that we should have to wait until $\mathrm{Al}$ Hami gave the word. That man looked to me then and I have no doubt would look to me now, exactly like a spy. He objected to everything, and especially everything American. It is this kind of man which causes the Sultan of Turkey to be much misunderstood. You could see from the spy's expression that he thought Arthur Moore was too big, physically; and he was sore he could not have him held. The Turkish spy is always small. 
But the guns were not to be had. That was plain after what $I$ had heard and seen and I did not want to stay an hour longer in the place than was necessary. So we decided to leave Jack Thompson behind us to wait for the cable from Constantinople and bring along the guns. $\mathrm{He}$ was to be taken to the mountains that night away from the mosquitoes and return the next, while Moore, Mr. Sneddon, the sick Englishman and myself, together with three soldiers as bodyguards, were to leave for Antioch, eight hours ride toward Aleppo.

Personally I was not sorry to leave Alexandretta. It is a miserable place built in the right angle of the Mediterranean, between Syria and Asia Minor. It is a small town with a large graveyard, and it is almost shoved into the water by the big meaningless mountains at its back. At a quick glance it would suggest the banks of the upper Snake River, in the northwest. The people have a washy yellow complexion, owing to the fever which is always present.

Its mosquitoes are smaller than the Jersey mosquitoes, but they are wilder, and have striped legs. They are the most deadly species of any mosquitoes in the Ottoman Empire. 


\section{MY QUEST OF THE ARAB HORSE}

When you once become aware that these mosquitoes are dangerous you are as watchful as if they were yellow jackets; you swing at the slightest sound. They sing in a higher tenor key than the Jerseyites. They are even still more elusive and I was surprised after my long experience in New Jersey that I could not kill one of these natives of Alexandretta. They were as wild as humming-birds, and in their flying, dipped in and out much the same fashion.

As Moore and I drove out of the town we saw an appalling sight. It was a little girl of about twelve years of age, whom the fever had nearly eaten away. She was coming through a graveyard with a jug of water on her head. Her lips were so drawn that her teeth were all exposed to view, and her arms and legs were mere skin and bone. She looked as though she had come from the grave. The graveyard through which she was walking was a low, marshy place where water buffalo wallowed in the mud among the rock-piled graves. Portions of the small valley between the town and the mountains were all taken up with swampy graveyards swarming with mosquitoes. It was a relief to get out of Alexandretta.

[58 ] 


\section{CONSTAN'TINOPLE 'TO AN'TIOCH}

But as soon as we came to the mountains we arrived at what seemed to be the cliff dwellers' home. There was a town of some size, built just as if the swallows had made it of mud, hanging from the mountains. The houses were perched on top of each other, all suspended from the cliffs above. Water rushed in ditches between the houses. This was the town of Baylan, the first place of safety from the fever we had reached since leaving the sea coast below.

The soldiers rode ahead of us to the thickest part of the village. We stopped there a few moments to take tea. During that brief space the whole population gathered around leaving their shops to take care of themselves.

We were now traveling on the finest mountain road I had ever seen. It was the old ancient Roman road and the same one over which Darley's Arabians had travelled when he was taken from Aleppo in 1703. We passed one point that looked dangerous; we could look over the bank more than two hundred feet down to the jagged rocks below. And then on and on we climbed over this wonderful mountain pass.

We saw small boys herding long-eared [59] 


\section{MY QUEST OF THE ARAB HORSE}

black goats; we saw the packs of many hundreds of camels stacked at the roadside. The camels were away being herded in the mountains for food. Then the night came on and we could not see anything. 


\section{CHAPTER VI}

\section{ANTIOCH TO ALEPPO}

WE reached Antioch at 11 o'clock that night. It was the longest eight-hour ride $I$ had ever taken. Shortly after we had left Baylan it began to become dark and Moore fell asleep in the carriage. Sneddon had been groaning with his fever. The soldiers were afraid to ride on for fear of Circassian bandits, who consider that part of the country their own. A tire came off the front wheel and the near horse dropped a shoe, but we hammered both on with rocks. It was getting quite dark, and jackals were barking here and there.

After miles and miles of valley road, we circled a lake towards some high rocky peaks. As we got near to Antioch we crossed an old, odd-patterned rock bridge, crossing the Pranties River and I woke Arthur and the sick man, as the carriage rattled onto the Roman pavement of the city. Our repeated knocks

[61] 


\section{MY QUES'T OF 'THE ARAB HORSE}

not only aroused the hotel-keeper, but all the world, wolf-like dogs, at the same time.

Our host was most civil considering the time of night. That is to say, he led us through damp smelling, rocky mud hallways to our room. This was an apartment about twelve feet square, that had windows looking out over the river. We were a scant story high. Underneath was a stable where we could hear

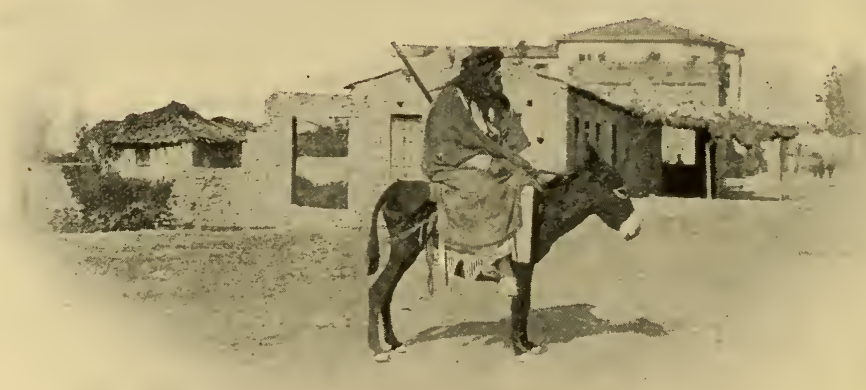

One of our escorts at Antioch.

camels grumbling and donkeys trying to bray and not quite succeeding. We were not very talkative. Moore looked at me as if he wished he had never seen me. I smiled a smile that [62] 


\section{AN'TIOCH TO ALEPPO}

was meant to hurt Moore, but hurt me worse. A half-naked filthy servant was trying to make us comfortable, but we had left our interpreter, Ameene Zatoon, with Thompson in Alexandretta and we could not understand. Sneddon spoke just enough Turkish to delay things. The servant only grinned when the latter talked and soon shuffled off apparently going nowhere. But there was a table in the centre of the room and also three benches. That was enough. We lay down on them and were soon asleep.

About an hour after, the ragged servant waked us up and invited us to eat. And we ate. What it was we never knew or really cared-we just ate it. Part of it was a sort of bread with which we sopped up the rest. All was washed down with boiling hot tea. Then we made down our beds on the benches. Meantime, I looked around the walls and at some small worn holes in the mud plastering, and roughly guessed the plot. Sure enough when the lamp went out the real hostilities began. I mistook the first two symptoms, but finally there was no mistaking. Moore and Sneddon were asleep, but restlessly so. The former fought as only a giant would, and even in his 


\section{MY QUEST OF THE ARAB HORSE}

sleep he sat up and pressed the button on a small pocket electric lamp, and swept the invading hordes onto the floor as fresh recruits to tackle me. I had previously left my socalled bed for the floor. Daylight finally came, and it marked the dawn of a new world's record for me. It was the longest and worst night I had ever put in. I dressed and got Baedeker and was not surprised at the way he describes the people of Antioch-“'The population, consisting of Greeks and Syrian elements are of a restless character."

When Moore woke up I read that sentence to him and suggested that we should probably always remember what it was that made them restless. The sun hadn't risen yet, but I found my way down to the stables and the yards below. As early as it was, the town and the markets were astir. For a long time I watched the curious bargaining.

For instance, just about sun-up, an old Arab and two sons came into the yard with a very old donkey, which must have been laden with five or six hundred pounds of some kind of dusty grain. The feeble old Arab left immediately and went away into the town. The sons spread out the grain for exhibition, but [64] 


\section{AN'TIOCH TO ALEPPO}

appeared as diffident as if they had never seen it. The father, it appeared, had gone off now to get buyers to come and see his grain, which he said represented the year's crop. I was anxious to see the return of this old agriculturalist of a type so different from the farmers I had known so intimately in the west. Presently the old Bedouin, with two buyers, returned. The latter seemed to understand each other. They lifted the grain in their hands, examined it minutely, and then slightingly threw it back.

The old farmer grabbed up handfuls and winnowed them to show its excellence, but the buyers feigned they were going away disgusted. At last the old man made a tearful appeal and the bargain comedy was well on. The old man asked the buyers to place their own value on the grain; it was the last crop he would ever raise; he was in rags, he pleaded, and he was only asking a pittance to encourage his sons to go on where he was now leaving off. A more dramatic appeal was never made to a jury. But it fell on deaf ears. I was ready to buy the crop and give it back to him, had I been nearer home. But it was a poor place to show money, so I swallowed my feelings while 


\section{MY QUEST OF THE ARAB HORSE}

the old man was weeping away his easily dried tears to await another cold-hearted buyer.

After that there was little to do and it was a relief when we left the old creeping, scratching town, jammed full of restless people.

We hadn't found anything that we could eat, and were beginning to get restless ourselves. We were to wait for Thompson at the junction of the Aleppo road at Caru Khan (Inn) for twenty-four hours. If he did not come within that time we were to go on to Aleppo. Mr. Sneddon had returned with the carriage and the soldiers to Alexandretta and going on to the Khan we waited. There was absolutely nothing to do. We tried to sleep on a veranda which was directly on the road. Our revolvers were handy and we felt safe from human beings, but that was all. After a few hours we again sat up just for spite.

Camels passed; several hundred at a time, in single file, as silently as if they were ghosts. They were heavily laden with liquorice root, and the only noise that came from them was now and then the squeaking of a pack. At the head of each long line of them were a dozen or so small donkeys, like a school of minnows leading a great band of whales. At two in the [66] 


\section{ANTIOCH TO ALEPPO}

morning a few jackals on the crest of the hill one hundred yards from us, howled and barked as if there were hundreds of them. In the distance we heard hyenas laughing in answer.

Then came more camels. Three hundred and eighty-six of them passed in silent procession, making scarcely a noise with their mushy feet and all slowly weaving towards the coast, laden with liquorice root. They didn't know it, but they were part of the Tobacco 'Trust. The whole of this load of liquorice root was for shipment to America, there to be spat upon the ground by the chewers of tobacco. It seemed quite possible that a large part of what the three hundred and eighty-six camels had on their backs, my old friend Bill Sterrett of Texas would use up in the next winter alone, and that if Bill would quit chewing, the percentage of camels that pass along the old Roman road would be noticeably less in the future. Up to date I have not heard that Bill has reformed.

Morning came and we tried, by signs, to show that we wanted to eat; but it was hard to make ourselves understood, and we lived on the scantiest rations through the hot day.

As evening came we saw some camel drivers $\left[67^{\circ}\right]$ 


\section{MY QUEST OF THE ARAB HORSE}

eating grapes, and our signs, more strenuous from hunger, made them understand that we wanted some. 'They gave and we tried to pay, but the chief of the party let us know that we were welcome without price. He then took us to where there were more grapes. Finally we found a native who could talk three or four words of English, and for these words we made his old age peaceful and prosperous by reason of the currency we heaped upon him. He soon began, with this capital at his back, to order men here and there, and through our sign language and the word "Haleb" (Aleppo), he understood where we wanted to go. We could see, however, because we were such easy marks, that he hated to understand. But about seven o'clock he kept saying the word "Post," "Post," and at last we gathered that at nine o'clock that evening the post coach on the way to Aleppo, would stop at the Khan and that he would, with our money, approach the big Khowaja (the conductor who carries the mail) and with more money we might bribe the great Turkish official to let us ride in the coach. Moore and I were skeptical about this, but curiously enough at nine o'clock along came the stage coach. The horses, four abreast, were

[68] 


\section{AN'TIOCH TO ALEPPO}

on the dead run. Four soldiers galloped with the coach, two at each side, armed with oldfashioned rifles. The stage halted, and with great pomp the Director General alighted. He was ushered up on the porch of the postoffice, where a feast of unusual proportion was spread for him. Arthur and I were kept back till the briber, with cur money, went forth. $\mathrm{He}$ began bowing twenty feet before he got to the great man and finally crawled up to him as he made known his mission. He dropped two gold pieces in his hands, and the agent, with much dignity, was open to reason. Finally we were brought forward and came like two whipped servants, but we were for doing anything for the opportunity to get away.

So after giving more gold, we were ordered into the low leather-covered carry-all and there lay in a half leaning, half sitting position, afraid to complain for fear we should be put off after all. But the gold had done its work and we were not disturbed. They were now hitching four stallions to the nondescript vehicle-two grays and two bays. They were better looking animals than we had seen on the carriages at Beyrout, or in fact at any place along the coast. They were hard and well [69] 


\section{MY QUEST OF THE ARAB HORSE}

kept, and wanted to get at their task. New soldiers took up their positions at each side of the coach. The driver climbed into his seat and beside him sat the man of dignity with a heavy rifle in his lap and our gold in his pocket. A groom pulled the mane from under the horses' collars and then with a peculiar low note from the driver, we were off at a gallop. At first we thought it was a runaway, but seeing no attempt was made to hold the horses back we came to the right conclusion that that was the regular schedule.

It was a wild night's ride. I was lying in a cramped position on the mail sacks, but the thrill of the rough rapid pace made my cheeks first hot then cold. In the dim moonlight the Arab soldiers galloping beside us, were like silhouettes and rode like our Indians of the far west. Down a long slope we dashed into a valley. My eyes were fairly popping with excitement, though Arthur was dozing. Of course we had the best of the mail sacks, the soldiers had spread out to detect any possible danger. While the four stallions were galloping true and strong, the driver suddenly yelled a long "Yeo!" "Yeo!" "Yeo!" I saw the soldiers dash ahead, drew my revolver and [70] 


\section{ANTIOCH TO ALEPPO}

shook Arthur, but couldn't wake him. But just as I expected to hear shots, I heard the gurgling of camels, and these heavy laden, tired-looking creatures were beaten out of the mail coach's right of way.

Our route then wound around the base of the mountain, and I could see a large band of jackals. At a halt, after passing hundreds of camels, we changed horses, and took on three dark bays or chestnuts, and one gray, and off we were again. Soon we passed a camel train. One of the beasts, a young one apparently, growled plaintively when he fell in a gutter and his heavy pack turned him in his fall till his light-colored belly loomed up in the moonlight. Feet in the air, he struggled while the Bedouins laughing, tried to quiet him.

We changed horses again before daylight, and a pup that hung around the horses was presented to me by the agent, and I tried to be polite in refusing the gift. We had a chance to stretch our legs, and Moore began to comment on the wonderful beauties of the ride. He had slept through it all, but that made no difference to him. He really thought he had been awake and wanted to know if I had seen things that had not happened.

[71] 


\section{MY QUEST OF THE ARAB HORSE}

The sun rose hot, and at first felt comfortable after the rush of the night. The roadbed was now strewn with small, round, loose stones about the size of hens' eggs and worn smooth by the cushioned feet of camels.

The last change of horses was truly remarkable. There were only three this time and they looked like old moth-eaten silk rugs. Two were white and silvery; the third was a bay with a coat as bright as gold. We saw them gallop over the stones for six or eight miles, and when they stopped for water, the bay pawed the stones and had to be held while the others drank. We both commented time and again on what our best horses would become under such conditions. From their appearance, these animals were of great age, and certainly their usage had been the hardest possible. Still, their legs were as clean as those of a colt.

Our entry into Aleppo was made in the forenoon. The sun was as hot as it could possibly be, without burning things - and we came in on the dead run. They put us out in the suburbs, because the mail officer (honest man!) was afraid we should be seen. The mail driver made us understand by his motions and the word "Arabeeye" (carriage), that he would [72] 


\section{AN'TIOCH TO ALEPPO}

send a vehicle for us to take us to the best hotel, so we sat down at the side of the chalkylike clay streets, in the shadow of an artificiallooking fig tree, and eventually, the carriage coming, we drove into the town.

For years I had imagined an entirely different Aleppo. I had pictured it as built in an oasis of the desert, with beautiful wide streets, clean and well-kept and lined with palm trees. I was wrong. In reality it is a city built of stone and mud. It has been tumbled down so many times by earthquakes, that it looks as tired as the old Roman road which leads up to it. Our driver turned into a small street not wide enough for two carriages to pass. The dogs were more plentiful than they were in Constantinople, and the stench was much worse. On the faces of all the young people were the sores of the Aleppo button, and on those of the older ones were the scars left by that disease, and this added to our general depression. We were half starved, and tired out from the night ride and the effects of the sun. Our spirits were low. To tell the truth we were thoroughly broken down. We had cold feet, although it was 125 degrees in the shade. The stench grew worse, and as the streets narrowed 


\section{MY QUEST OF THE ARAB HORSE}

down, and the people followed the carriage to have a better look at us, I said to Moore, that if the driver stopped then, and asked us to get out at a hotel, I believed I would collapse. I had already given up. The letters which I had in my pocket and

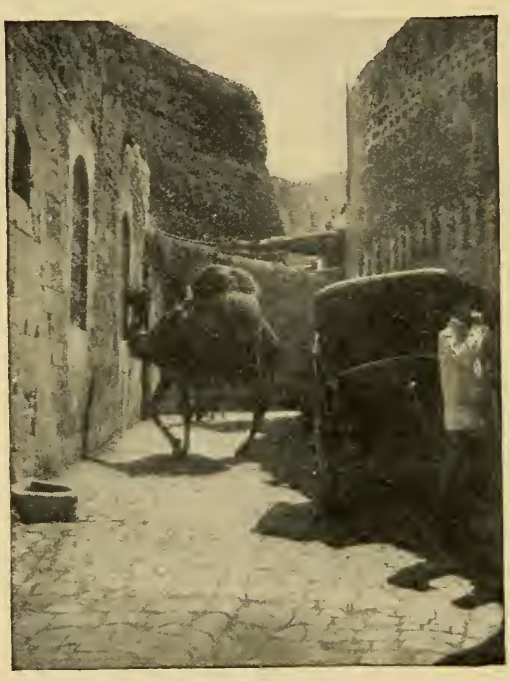

Old methods of travel giving way to the new in Aleppo.

the Irade permitting me to export horses and mares, were losing their stimulating power. For years my idea had been so different of Aleppo, that the shock was more than I could stand. Then while this thought was in my mind, in the $\mathrm{midst}$ of the very worst street and next to a most ill-smelling shop, our driver halted, and motioned to us to get out. Arthur refused to get out of the carriage and as one of us had to do so, I did and walked in to what they called a hotel. They 


\section{AN'TIOCH TO ALEPPO}

were driving a mangy dog and a dozen puppies out of the room which was to be ours, but I couldn't take it. A man came and asked me if I could speak French, and although I couldn't, I held on to him by the arm. The natives could not understand "America" or recognize that word. Then Moore suggested "MacAndrews \& Forbes," and the man who spoke French took us to his place, where we met a protector in the form of a young Englishman of the name of Beard, and we hung to him on both sides. He took us to a better hotel, where they had a garden; that is, in the court, they had a potted palm or two, and in a little dusty corral a fat-tailed sheep, a donkey and a few chickens. It was as clean as a hotel could be in Aleppo, and most of the foreign consuls ate there of evenings; some of them slept there two or three nights of the week - and then tried some other place. I had not had, to my knowledge, any sleep on the coach and Moore refused to admit that he had had any, so we immediately went to bed.

The next morning at daylight Jack Thompson came, with our interpreter and the guns. He had lost one of his teams over a high precipice and he and the interpreter had almost lost

[75] 


\section{MY QUEST OF THE ARAB HORSE}

their lives. A camel train had crowded them as they came along in the night, and just as the team fell over the bank and tore itself out of the old harness, the men jumped out in the nick of time. Barring this incident Thompson had some sleep and was feeling better than either Moore or myself. He was quite excited at being in Aleppo. 


\section{CHAPTER VII}

AKMET HAFFEZ AND THE WAR MARE

Even the arrival of Jack Thompson with the guns could not get me out of the blues. Of course we were in Aleppo (not the Aleppo I had imagined!), but it did not seem likely that we should get much further. We had had nothing but discouragement from the MacAndrews \& Forbes people and I began to believe that our journey was over without the accomplishment of what I thought I was so well equipped to carry out. I was utterly down in the mouth. Moore and Thompson evidently thought that something should be done to cheer me up (though they themselves were pretty melancholy) and so decided that if they could get me to some shop with an atmosphere of horse about it, I might be brought into a better frame of mind. Accordingly, with our interpreter, and with Beard, as a guide, we started 


\section{MY QUEST OF THE ARAB HORSE}

for the shops where they made the saddles and bridles, and horse trimmings which were used in the desert. In the poorly ventilated bazaars hundreds of Bedouins crowded around to look at us. The ignorant stared while the better bred greeted us politely. To see three strangers, the smallest of whom stood six feet one and a half inches, was a sight to them. They peered at us genteely, and asked the interpreter if we were "Engleese." They shook their heads, as he explained that we were "Americs" and wanted to know where "Americ" was.

While we were at the saddlery place, in the crowd of Bedouins looking on, I saw one who looked a little darker than the rest and whose teeth were peculiarly white. I remembered reading in one of the Blunt's books, that the Anezeh tribe had peculiarly white, chalk-like teeth and $I$ at once told Ameene, the interpreter, to ask this Bedouin if he knew anything about the Anezeh. We had heard at Beyrout that the tribe was then two or three hundred miles south of Palmyra. Moore, in a goodhumored, sarcastic way, said: "Here, if you are going to try and find the Anezeh in Aleppo, I will quit you; this man never heard of the Anezeh, he is a camel driver." While the 


\section{AKME'T HAFFEZ AND THE MARE}

translation was made to the Arab his eyes grew very expressive and round, and he said in return. "The Anezeh are within ten hours' ride of Aleppo; I am a member of one of the sub-tribes and have just come from them."

At this Moore and Beard laughed and went off in disgust to look at some silk rugs. I let them go without a word. In a moment I saw another Bedouin, an older man with a grayish beard, but with the same peculiar white teeth, and from him, too, I inquired the whereabouts of the Anezeh. His answer confirmed the story of the first and he added something that brought me back to my normal spirits. $\mathrm{He}$ declared that Hashem Bey, the Sheikh of all Sheikhs, was then in Aleppo paying a secret visit to a man named Akmet Haffez, the diplomatic ruler of the desert. He offered to take us to the house of Akmet Haffez. Jack Thompson's eyes began to sparkle again, and Ameene grew excited. If this were true, it seemed beyond a doubt that we could buy our horses directly from the Anezeh tribe itself. It was no longer a question of going to Deyr.

We lost no time in getting into a carriage in which we drove through the narrow, dirty streets for a long way, passing 


\section{MY QUEST OF THE ARAB HORSE}

old crumbling grave-stones in the middle of the town and then to the outskirts, and up to a two-story stone and mud house. Our cavass went inside, was gone five minutes, and returned. We were taken upstairs to an inside large room showing every sign of wealth. The furniture was spotted with inlaid pearl, and the divan, which ran all round the room, was of purple plush with gold and silver ornaments. Scattered over the divan were rifles that looked ready for action. Before we had time to think that this was strange, as only the soldiers were allowed rifles, everybody else in the room stood up and we too arose. Then slowly and with a stride like that of Sir Henry Irving, a noble, elderly looking Arab came forward. Anywhere he would have attracted instant attention. He looked like a bronze Grover Cleveland in his last years. His eyes fairly glowed with smiles as he bowed low on the magnificent silk rugs. This was Akmet Haffez, the ruling Prince of all the Desert! He took a seat on the divan and as servants put soft pillows beside him, he pointed to me to take a seat at his right. His slippers fell carelessly off as he drew his feet up under him in Turkish fashion. Instantly a slave was pouring into small thumb[80] 


\section{AKME'T HAFFE' AND THE MARE}

like cups coffee which we had to drink, lest an insult might be offered.

Ameene, our interpreter, now spoke, and told him why our sudden call was made and Akmet Haffez told us that Hashem Bey, the Sheikh of the Anezeh, had been his guest for ten days, but had gone the night before, back to his tribe, which was encamped at a distance of ten or twelve hours' ride.

The dignified old gentleman then learned we were the people who had been in Antioch three nights before.

"These then," he asked, "are the people, one of whom has an Irade from the Sultan of Turkey, and letters from the one Great Sheikh of all the Americ tribes?"

"Yes," he was told.

The old man's eyes filled with tears as he looked at me, and his slaves and secretaries grew more interested, when turning toward Ameene he said:

"Then you have called on me before calling on the Governor of Aleppo and Syria. No such honor was ever paid to a Bedouin before, and if I should live to be one hundred years old, my smallest slave would honor me more for this visit." 


\section{MY QUEST OF THE ARAB HORSE}

He was much moved and so was I; not so much because I seemed so unexpectedly to have attained my fondest hopes, as because I had met with a man. It was difficult to find exactly the right thing to say through an interpreter, but this fine old Bedouin was equal to the occasion. Repressing his emotion he said with a deprecating smile:

"But after all you have not come here to see men. Better than that you have come to see horses, and I would be selfish if I kept you longer from seeing the greatest mare of our country-the war mare of the Great Hashem Bey-the mare from whose back he killed, among others, his most distinguished enemy."

A servant was dispatched for her. She was, Akmet Haffez said, a present to him from the Great Sheikh, who had just been his guest; that in their religious custom no present could equal her; nothing but a gift from Allah, himself, could surpass her.

The servant returned and, led by the hand of this old man who was so imprescing his individuality upon us, we went down to the court yard. There stood a black slave groom with two mares, a chestnut and a small bay. Several hundred Bedouins and townspeople had 


\section{AKMET HAFFEZ AND THE MARE}

gathered, but they fell back leaving an empty space for the mares.

The war mare, the present from the Supreme Ruler, was the chestnut. She seemed to

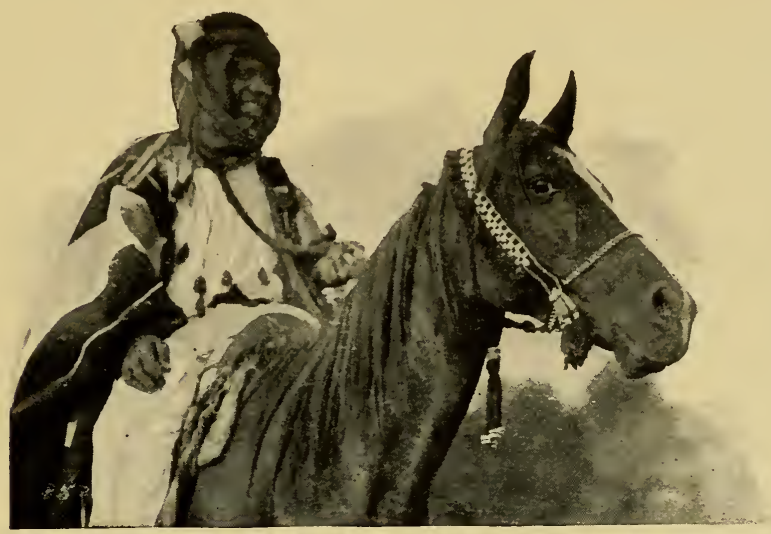

My Royal Present, Wadduda, the War Mare, with Said Abdalla

be fretting to get out of the only town she had ever been in. In her highly carried tail, I saw some blue beads tied gracefully in her hair. I knew they were to keep off the "Evil Eye." I went up to her, but she put back her ears as if she would bite or strike or kick. It appears that I, in European dress, was the worst object she had ever seen. Her name they told me was "Wadduda," meaning love; that she was a Seglawie Al Abed, seven years [83] 


\section{MY QUEST OF THE ARAB HORSE}

old and had been the favorite war mare of Hashem Bey for four years. She didn't like the town, she wanted to go-and those who told me pointed to the desert.

Two fine looking young men came up. They were introduced as sons of Akmet Haffez, who proudly referred to them as horsemen. The crowd was dense by this time, and the excitement ran high when the Bedouins were told that I had called on Akmet Haffez before I had called on Nazim Pasha, the Governor. Many of the rank and file kissed the old Sheikh's hand in joy. Others came close and touched their cheeks to his.

In the meantime, the older son Ali, who had galloped down a stony street on the war mare, cried out and was turning to come back. In a moment, she came tearing down toward us all afire, and the bounding tassels around her knees, looked like silk skirts. Such action over such rolling rocks! Her tail was high and her eyes fairly sparkled!

The son then rode the bay, a smaller Abeyeh Sherrakieh, with the greatest jibbah or forehead, I ever saw. This small mare had even more fire than the other and we were afraid for a moment that some child would be hurt [84] 


\section{AKMET HAFFEZ AND THE MARE}

in the midst of her play and frolic. After this exhibition Akmet Haffez led the way to the court of his stables across the streets through the gates in a high mud wall and ordered the mares to be taken into an enclosure where he had many horses picketed. Before the big gates were closed he called by name several of the elder Bedouins and as they came through they touched and kissed his hand.

The gates were then closed, and he stopped and extended his open hand as if to grasp mine. As I advanced to take his hand, his other gracefully warded me back. All this time the old Sheikh was talking in an emotional voice to the interpreter. I was fearful for the moment that I had offended him in some way, though I could hardly think how. I looked upon Ameene to explain. I saw the interpreter's face grow full of astonishment and wonder, and turning to me he said:

"It appears that we have made a diplomatic blunder in calling on this man before we have called on the Governor, and he feels so deeply affected by it, that he wants you to take his hand, but not unless you can accept the great war mare as his present to you, with the Bedouin boy that now holds her. Her name is

[85] 


\section{MY QUEST OF THE ARAB HORSE}

to remain the same, Wadduda. He hopes that when you speak the name it will bear living witness of his love to you and that the gift and its acceptance will be the forming of a friendship and later of a brotherhood that will never end."

I was so much concerned at this, that I asked Ameene if I could accept such a present. The interpreter told me that under ordinary circumstances 1 could not, but under these conditions, I would insult Akmet if I did not comply with his wish.

So I accepted the mare and the hand of brotherhood and the old Bedouin ruler seemed very happy. He told me that no money could buy the blue beads from the mare's tail, and that, for the moment at least, seemed true. When Akmet Haffez learned that Thompson was my traveling companion he immediately presented him with a young gray stallion. I am sorry that I did not have a moving picture machine so as to have photographed the antics of Jack when he realized that this horse was his. But in his demonstrations of joy, he brushed by and reminded me that a little over an hour before I was suffering intensely 


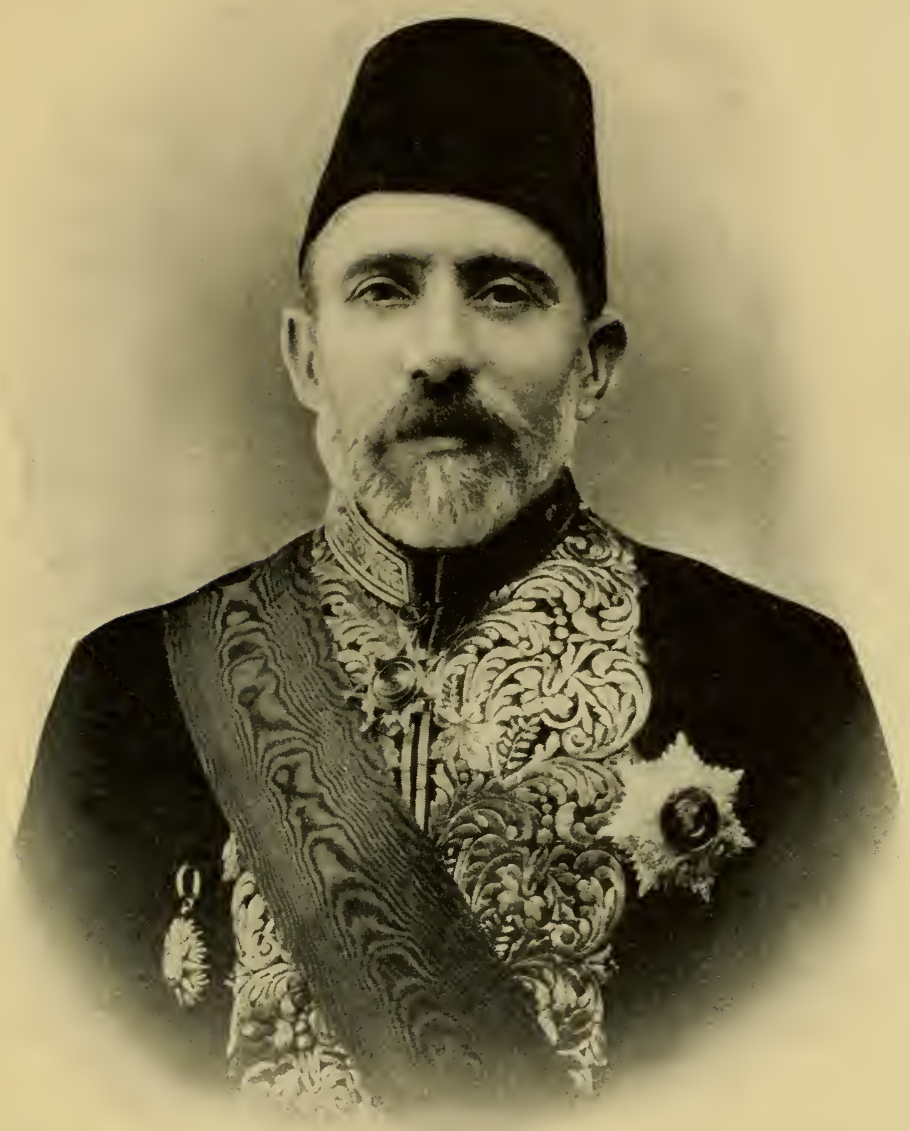

Nazin Pasha, His Excellency the Governor of Aleppo. 


\section{MY QUEST OF THE ARAB HORSE}

from a malady called "blues" and asked me, as he pinched my side, if $\mathrm{I}$ had them now.

Akmet Haffez was soon dispatching a messenger on a Delule (racing camel) to the Anezeh. When we inquired why, he said he was telling them not to move tent, or go into war, for he was coming the next day with us and that it was his first visit to his tribes in nearly thirty years.

Accompanied by Akmet Haffez we then called upon Nazim Pasha, the Governor of Aleppo. The Governor received us warmly despite our break in etiquette. He sent for coffee and cigarettes, and lit mine for me. We talked of many things. He held a letter from President Roosevelt in one hand, and pointed to God with the other. Then he said a prayer. He told us that God must have brought us to Akmet Haffez. At this point the old Bedouin slid off the divan, and knelt in prayer. The Governor continued that he wanted Haffez to take us to the Great Anezeh, at which Haffez slipped off the lounge again, like a mountain sheep, and again knelt in prayer. When told of the present I had received the Governor bowed and touched his forehead, issuing a characteristic grunt in a deep bass. $\mathrm{He}$ was [88] 


\section{AKME'T HAFFEZ AND THE MARE}

anxious to see my Irade, and again he seemed to ask a blessing as it was being translated to him. He told us as Akmet Haffez had already done, the story we had heard in Constantinople, of his brown stallion, a Maneghi Sbeyel, a present to him from the combined tribes. He insisted that we must come the next day to his stables and see the horse.

When we got back to the hotel Moore was there, and he began to laugh and asked us if we had found the Anezeh. We pretended for a while that we had been fooled, but he saw that we were enthusiastic over something and we could not hide the truth. None of us could sleep that night, because we were to start for the Anezeh tribe the next afternoon, where we should see members of every big tribe of Bedouins that go to make up the Anezeh people. And all this due to a simple question about a Bedouin and his white teeth. 


\section{CHAPTER VIII}

THE WAR MARE GREETS THE DESERT

A t ten the next morning we went with Akmet Haffez to the Governor's residence. Nazim Pasha had promised to let us see the "Pride of the Desert," the great brown stallion presented to him by the Bedouins. I was glad to have that opportunity for Mr. Forbes had already told me of the horse as you will remember; but the heat was stifling, the reflection of the sun from the red and white sand was killing and I was anxious to get off to the Anezeh with Akmet Haffez.

Frankly I did not expect much of the "Pride of the Desert." I really resented the waste of time involved in this call on the Governor. Especially hard was it to go through the motions of drinking coffee and smoking cigarettes. I thought the time would never come when all the necessary eastern hospitalities would be over, but they came to an end at last and we [90] 


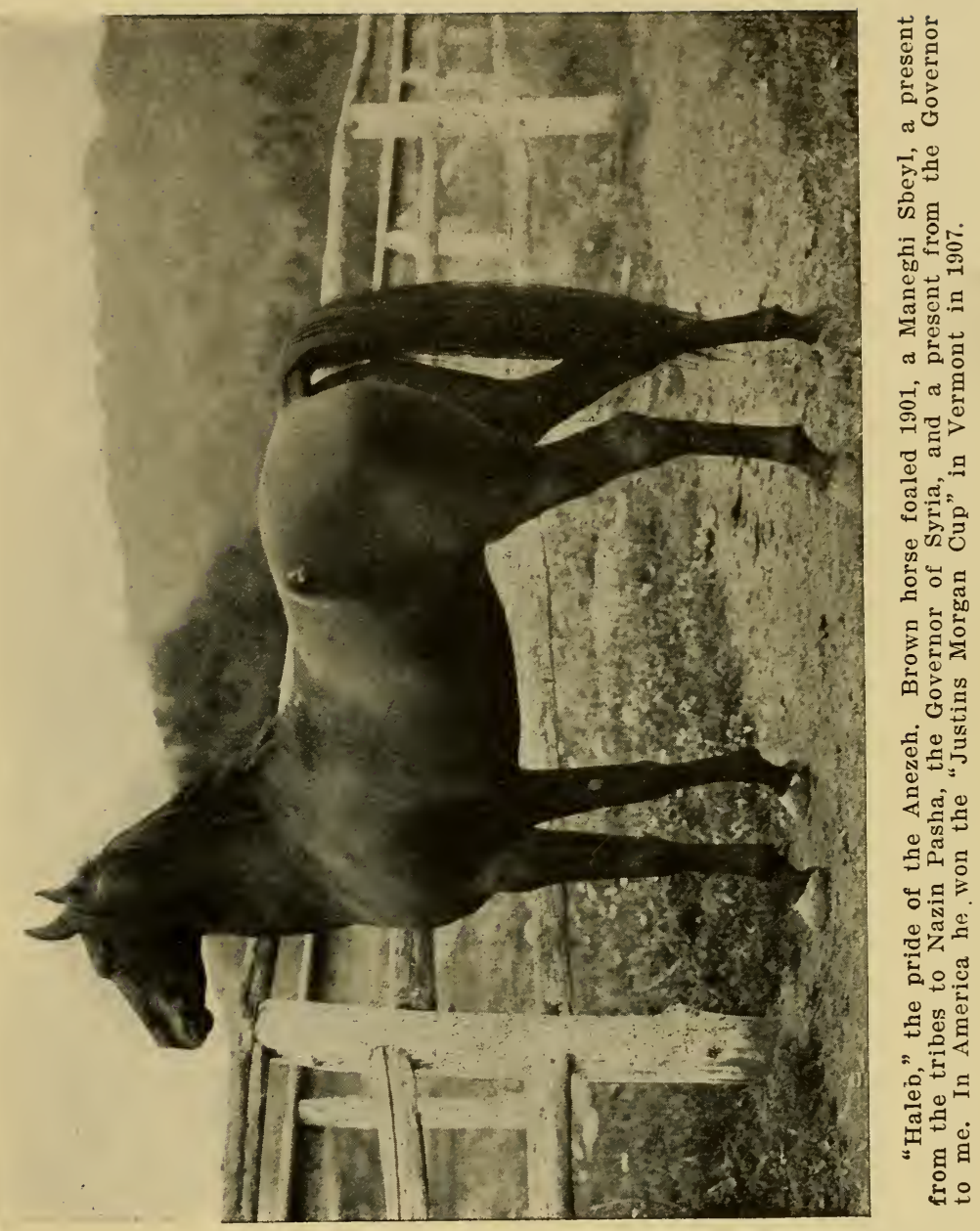




\section{MY QUEST OF 'THE ARAB HORSE}

were taken to a balcony of the palace to see the Governor's horses.

Right now I want to apologize. I had not known what I was to see or what I was to receive. It did not seem at all probable that the "Pride of the Desert" would amount to much -but when he was brought to the court yard I apologized to myself as I am doing to you now. We forgot all about heat and sun reflection. We could only think of the horse.

He was of the pure Maneghi Sbeyel strain and what a stocky fellow he was! $\mathrm{He}$ was powerful enough for any purpose, especially for a long killing race where weight was to be carried. There was not a white hair on him, and Akmet Haffez began on his fingers to count the stallion's pedigree through his dams' side, each one of which had been the greatest mare of her time. Other horses were shown, but we remembered only the brown stallion.

And here came the second surprise. Just as we were leaving the Governor's palace, he asked me to accept the brown stallion as his present. I had taken the war mare from Haffez, he said, and so I should accept this horse from him. This seemed to be beyond reason. The Governor was a poor man, and we had [92] 


\section{THE WAR MARE IN THE DESERT}

heard of the failure of the Italian Government to secure the horse, although a large price had been offered for him. But the Governor was firm.

"You have accepted," said he, "the present of the war mare, Wadduda, from Akmet Haffez; you must accept this horse as a present from me."

So I did, but later in the day I sent to Hickmut Bey, the Governor's son, as a present, a check for one hundred French pounds. Honors were therefore easy, but nevertheless I had had presented to me on the eve of my start for the desert, a mare and a stallion which I could not have purchased with all my letters of credit.

The rest of the day was taken up in preparing for the journey to the desert with Haffez. At five o'clock we had left Aleppo. I rode Wadduda; Haffez was on a bay, four years old, a Hamdani Simri; Thompson contented himself with his gray, and Moore straddled an Abeyeh Sherrakieh mare. One of Haffez's sons rode the "Pride of the Desert." A priest was sent as a secretary, and Ameene, of course, accompanied us.

The Governor had picked twelve soldiers to [93] 


\section{MY QUEST OF THE ARAB HORSE}

go as a guard, but I suggested that there was no reason for a guard when Akmet Haffez was with us; his presence was more than an army. The suggestion made an instant hit and when I asked the reason Haffez explained that the Bedouins had a poor opinion of such Europeans as they had seen because they always came to the desert surrounded by soldiers. The Bedouins believed that all Europeans were cowards. So, save for the rifle which I was carrying to present to Hashem Bey, we were without arms. Several camels with tents and provisions, had gone on with cooks and extra camel men. It was a gala occasion. Akmet Haffez had not been outside of Aleppo for thirty years and, as he rode by my side, like a fine old Indian chief, his followers who lined the streets, were full of enthusiasm. It was a great evening. Still one thing bothered me. I had not yet made friends with my mare. She fretted and was nervous. I was on her back without the flowing robes usually worn by the riders she was used to. Jack and Arthur had donned Arab costume, but at the last moment I could not give up my flannel shirt and my comfortable ragged coat and trousers. So I [94] 


\section{THE WAR MARE IN THE DESERT}

broke the rules of the desert and went as I was dressed.

I argued to myself that some time Wadduda would have to get used to me and my clothes and that she had best begin at once. So I let her fret. We rode on for miles over dirt and rock and Wadduda still seemed fretful. She wanted something; that was evident, but what it was I could not quite make out. Then suddenly I was enlightened.

Just as the big red sun was setting we came to the desert. Wadduda stopped as if she were paying some tribute to the closing day. The faint roadway now seemed to disappear and before us was a vast barren plain. The sky was of a soft blue, tinted to gold by the sun, which had just set. I turned in my Oregonmade saddle, as easily as I could, that I might see where the rest of the caravan was. The mare did not notice my turning. With a quick and graceful toss of the head, she began to play. I sat deep down in my saddle and let her frolic uninterrupted. She finally stopped short, and snorted twice.

Turning slightly to the left she started galloping with a delightful spring. It was the return home, the call of the wild life with its [95] 


\section{MY QUEST OF THE ARAB HORSE}

thrills of wars and races; with its beautiful open air, as compared with the musty stuffed corral she had been picketed in. She was getting away from civilization and back to the open. Once in a while she stopped short, apparently to scent the rapidly cooling atmosphere. Now and then she pranced, picking her way between camel thistles. Her ears were alert; her eyes were blazing with an expression of intense satisfaction. All this time, I found by my wet cheeks, that I had been crying without knowing it. I was wrought up to a state of much excitement. I was again a boy and felt the presence of my parents, and recalled the stories of the Arab horses, they used to tell me when I was a child. I remembered the drawings I had made of them as a boy. It was hard to realize that I was $I$, and that I was astride the most distinguished mare of the desert. I seemed then to realize what she was and what. she meant to me. $\mathbf{M y}$ face was dripping again and I felt glad I was alone.

Wadduda had stopped short again and was scanning the horizon. I touched the mare with my heels, but she did not move. She was thinking. Of what, who knows? Perhaps of her wars; or of combats on the desert, or of [96 ] 


\section{THE WAR MARE IN THE DESERT}

the keen edge of the Bedouin lance given when she had seen both horse and rider fall from the thrust of the spear of the Great Sheikh who had ridden her.

So for a long time we waited together-the mare and $\mathbf{I}$, in the gathering dusk, and as we waited I almost wished that we could always be alone. The call of the desert came strong to both of us then.

But we were not to be left alone for long. The mare and I had ridden far in advance of the caravan, but now the people were galloping along in an effort to catch up. They soon reached us and Akmet Haffez, who would not let me go astray in the desert, took his place on my left, and so we rode and talked on and on into the beautiful night. I was tired from the excitement of the secret which only Wadduda and I knew and it was a relief to have Moore and Thompson tell me something that rested me. We were going to stop about midnight at the camp of a cousin of Akmet Haffez. We were to have a midnight dinner and start before sun-up toward the Anezeh.

But it was after midnight when we came to the singing and joyous Bedouins, who were [97 ] 


\section{MY QUEST OF THE ARAB HORSE}

shouting "Akmet Haffez!" "Akmet Haffez!" as we dismounted rather stiffly.

I helped take the saddle off my mare, and then we were ushered into a tall, cone-shaped mud house and escorted to a divan where the quilts and rugs were thicker. Before us, face down, on the clean, beautiful quilts, was the cousin of Akmet Haffez. He was mumbling a prayer and our interpreter softly translated it. The prayer was a beautiful sentiment. The petitioner was asking God to release him ever after from work so that he might stand at the caravan routes and tell all generations of the great honor that had been paid to him by us who were going to eat his rice and melons and who were to distinguish him further by sleeping under his shelter. It is true that the prayer was more eloquently thankful than most hosts would indulge in for a party so big and so hungry, but at the close of it we were led out into the yard where all his cattle and goats and sheep were resting and the sight of them made us more cheerful. Then we were taken into the cone-shaped mud house and there was a feast, long to be remembered.

It was spread on low tables about a foot from the ground, with short-legged little [98] 


\section{THE WAR MARE IN THE DESERT}

wicker stools for us to sit on. On the tables was spread bread about an eighth of an inch thick and this served as a table cloth. The bread baked on rocks in the sun, was made of barley and wheat rolled, and now and then in eating it you came to a full stop; a period as it were, consisting of a small gravel. In the center of the table was a large mound of finelycooked rice and on top of this mound was a roasted head of sheep. The carcass, nicely roasted, was strewn around the mound of rice at intervals. There were red, yellow and green melons; egg plant, chicken cut up fine, and clabber milk of the goat, sheep, camels and cows. There were grape leaves rolled with rice in the center and there were fine light green grapes and fresh figs. To drink there was a mixture of sour milk and water.

When we sat down, I saw Akmet Haffez rolling up his sleeves. I saw no plates, knives or forks, or even spoons, but I took the hint quicker than Jack or Arthur. Possibly I had always lived nearer to the ground than they. Akmet Haffez had no sooner plunged into the rice than I did the same. His motions were easy to imitate, still the Bedouins laughed heartily at the quick way I mastered their [99] 


\section{MY QUEST OF THE ARAB HORSE}

simple art of eating. We ripped and tore at the table cloth and at the other dishes for more than an hour, and then having washed our hands out of a peculiar brass pitcher, we returned to our sleeping rooms. The program was to lie down and sleep till about three o'clock, when we were to start again and ride, reaching the Anezeh, we hoped, before it got very hot. At three o'clock we were saddling the horses and were soon off.

A couple of hours after sun-up, we began to realize that we were really in the desert. Two Arabs on mares, a gray and bay, came galloping toward us. They were carrying spears that looked fifty feet long. As they approached Haffez, they stopped and said "Salam Alakum-"Peace be with you." They talked for some minutes, when Ameene told me that some of the Anezeh had gone across the Euphrates to war, but that Hashem Bey had left his cousin a few miles on where the latter would receive us. We were disappointed that we were not to meet Hashem at once, but there was really no room for complaint, and with the couriers with the long spears we went on.

It was about eleven o'clock when we reached [100 ] 


\section{THE WAR MARE IN THE DESER'T}

the top of a small knoll. I was sore and tired for I had not ridden for so long in years and the heat must have been telling somehow on my expression, for Akmet Haffez yelled to me to cheer up and pointing on ahead shouted: "Anezeh!" I looked, but could see nothing. After a while, through the haze I noticed that the plain was covered with blackish tents and camels. And then the whole plain seemed to be covered with camels. In the distance they looked like row after row of tea-kettles. Wadduda was prancing. She had seen her tribe first. Tired as I was, it was a thrilling sight. It was the realization, at last, of a wish that I had cherished since a small boy, and my emotions got the best of me. We could see horsemen racing here and there. They were preparing to greet us and were getting into holiday garb.

Frankly it was too much for me. I tried to tell Akmet Haffez through the interpreter what I felt and to thank him for what he had done, but I am afraid I made a mess of it. That kindly old man saw my emotion and replied with all the native courtesy of the desert combined with the manner of the true gentleman. It was an honor to him, he said,

[101] 


\section{MY QUEST OF THE ARAB HORSE}

that we had allowed him to introduce us to his Anezeh.

We were now getting near to the outskirts of the camp, and though I was as sore as an Aleppo button looks, under the excitement I urged on. We saw a big grass plot in front of a large tent. Haffez rode straight for it on his mare and as he dismounted, men came out and kissed him on the cheeks. All of the big officials had done this when an Arab took my mare and I got off. I could hardly walk and the heat was making me dizzy. I tried to be unconcerned, but my hips and knees were about broken. Sheikh after sheikh we met, and we bowed and touched our right hands to our lips and foreheads as they did, and then shook hands. We were led in under a big reception teni. The bridle from my mare was brought in and tied to the center pole of the tent, denoting that we were welcome. We were at last among the Fedaan Anezeh, the most warlike and most uncivilized race of Bedouins in the world. To be frank again, I was much overcome with emotion to realize that we were in the tents of the greatest war tribe of Bedouins and under possibly the most favorable conditions possible.

[ 102 ] 


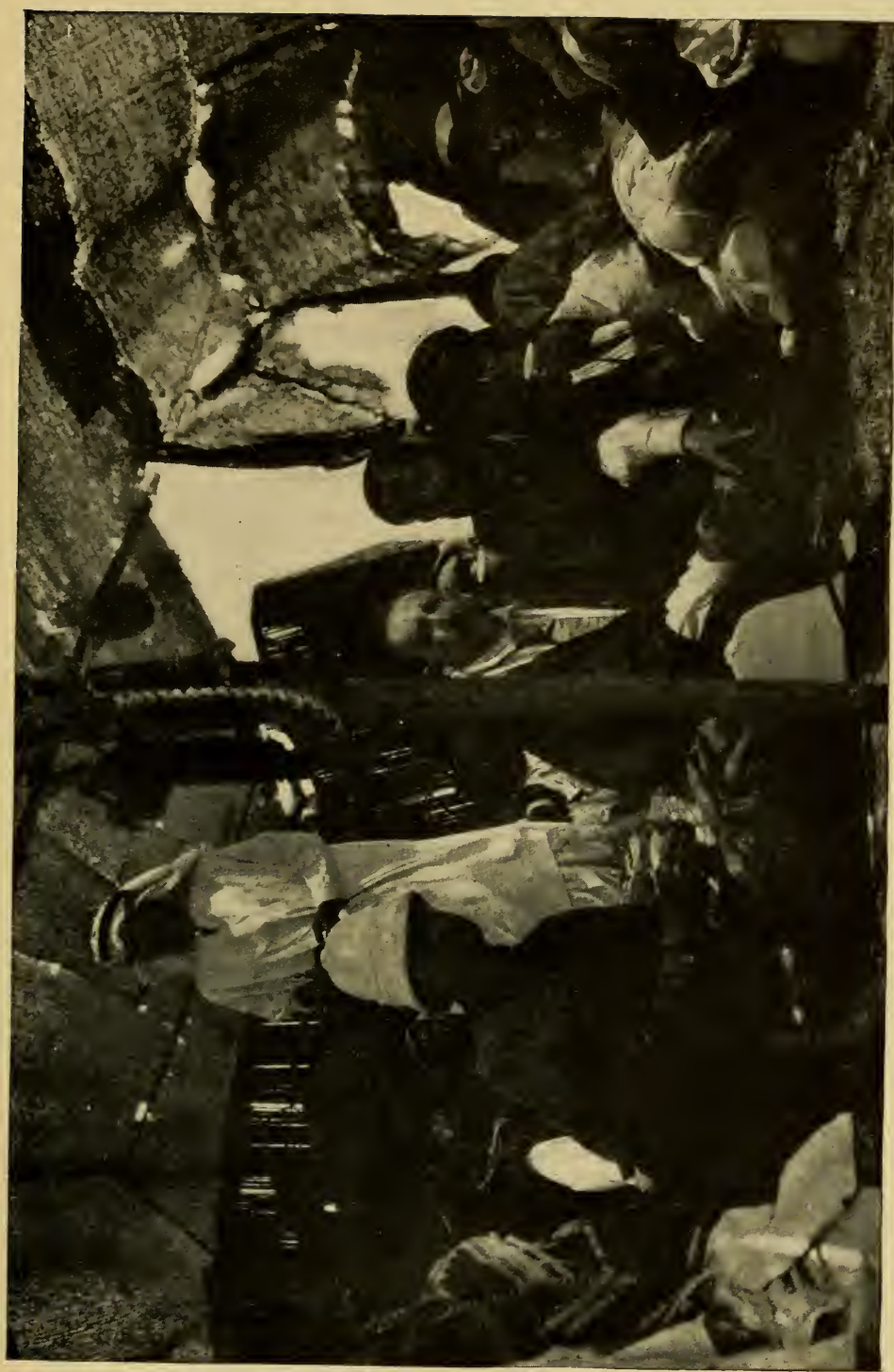

先

링

它空

。․

正

월

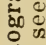

을.

क

宽

한

สำ

घิㅇํ

$45 \frac{1}{0}$

《安

舍

可边

o $0 . \Xi$

고용

क्षे

चี भु

연

인

कo

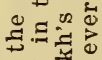

을

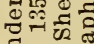

马ี

당

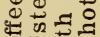

$8 \overline{80}$

फ

b ․․ㄴ

?

ำ ฮี

i

讪政

纪》

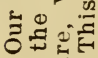

สั ฮั 


\section{MY QUEST OF THE ARAB HORSE}

Ameene felt that it was up to me to say something. Too tired to stand, almost too weak to talk from the heat, hunger and thirst, still I leaned toward the interpreter, and asked him to tell Akmet Haffez and the Anezeh, that while I had been born in the far western part of what he called "Americ," I had realized, ever since a small boy, that I was just as much of an Arab as any in the desert and that now that I had seen the Anezeh tribe, I felt I had been one of its members all my life. I thanked Akmet Haffez for bringing me to such a people, for it was the supreme moment of my life.

Without hesitation, this old man reached across the camel's saddle and with a voice full of emotion said:

"No, the day is ours, not yours; ever since the Anezeh became a tribe we have known that one of us was missing. Now you have come and the number is complete. To-day we celebrate the gathering of the entire tribe."

And thus was I received by the Anezeh. 


\section{CHAP'TER IX}

WE FEAST WITH THE ANEZEH AND BECOME BETTER ACQUAINTED-INSPECTION AND PURCHASE OF HORSES

This interchange of formalities and courtesies broke the ice and we instantly felt that we were at home in the Bedouin camp. Our hosts brought us a delicious drink of water mixed with curdled milk of the sheep, goat and camel, and we did not in the least mind that the water was muddy or that the mixture was stirred in a dirty pail with a dagger. We liked it all the more. Presently the slave who makes the coffee began to beat time on a large wooden bowl with ornamental sides. The stick he used was heavy, and in the noise there was a ring of ragtime that was fascinating. No tune ever impressed itself on me more than that weird coffee beating, the muffle sound of which could be heard a quarter of a mile.

Coffee galore was served, but I had to de[105] 


\section{MY QUEST OF 'THE ARAB HORSE}

cline. Haffez explained that I did not drink coffee, or smoke, but that he would take my share, and the grim Bedouins smiled. Never have I seen such a gathering as was seated under the big flat-topped tent; Bedouin after Bedouin, as handsome warriors as one could imagine, all with beards, except the young men and boys and all so black that their high lights were really blue.

Hashem Bey's cousin told us how sorry the great Sheikh had been to leave before our arrival, but that as the war was not believed to be a serious one, he would return in a few days with the 2,500 mounted men he had taken away.

Our camels had now arrived, and our tents were pitched facing the Sheikh's, and many Bedouins were set to clearing the space of its rocks.

They were anxious to see a letter from the Governor of Aleppo to their Sheikh, and the latter's secretary read it aloud. It must have been a pretty strong document, for at intervals everybody bowed, and touched their mouths and forehead with their hand. Then soon it was time for the feast. About two o'clock four men came, carrying an immense 


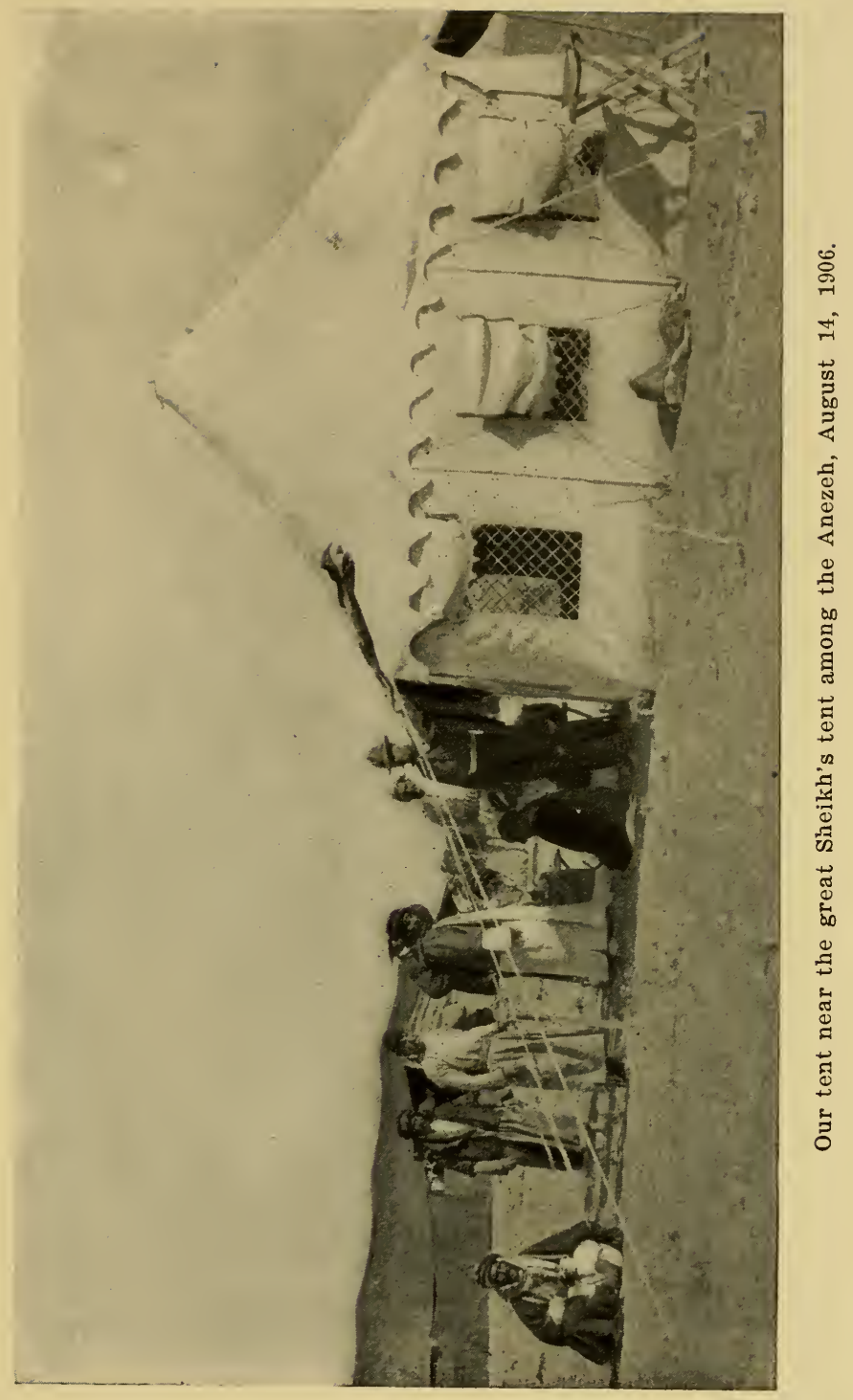




\section{MY QUES'T OF 'THE ARAB HORSE}

pan with more than two washtubs full of boiled rice on it, and on top of that a roast sheep. We began to brighten up. More sour milk, and grapes, and bread that looked like saddle blankets followed the sheep. About twelve Sheikhs ate with us at the first table. And never was there such rice and mutton! We must have consumed a third of it before it was given over to the rank and file, who put the crimp on the rest of it in short order. By this time our tent was up, and full of Bedouins looking at things. They were driven away by Sheikh Ali, and we were invited to sleep, which we did without being rocked. There was a quiet air to the place which seemed more restful, and in the morning I was up at daylight looking over the horses picketed here and there. Finally, picturesquely-dressed Bedouins began to appear.

Not one of them was hurried. Everybody walked slowly and with a dignified sway. There was no rushing for the 8:17 train; there was no hurrying for the ferryboat; there was no worry over the market; there was no excitement over politics. Until I learned better that you cannot "hustle the East" this repose (you cannot call it laziness) seemed very

[ 108 ] 


\section{THE FEAST WITH THE ANEZEH}

strange. Later I began to like it. These big handsome men with well-kept beards and sparkling sharp eyes, seemed to have nothing to do, but when you had watched them for a while you could see how alert they are. They were anxious to see our firearms and knives and jewelry. They commented, with astonishment, on my knowledge of the technical points of their own horses. My pronunciation of words was often bad, but they knew that I had a fair knowledge of the different breeds and they brought up stranger after stranger that they might enjoy the astonishment of the latter when I went over the families of the Khamseh, or five great families of the Arab horse. When the sketch books were opened, and I began to draw pictures of horses and men, their joy was almost childlike.

Thompson and Moore had been exhibiting their cameras, but after they had seen me draw with just a plain pencil, they would have none of the camera. They examined the pencil and looked at its point. When they used it, they said it only made marks, but when I took hold of it it drew their horses, so it must be that I, they argued, was better than the camera.

Our saddles were strange to them, especial[ 109 ] 


\section{MY QUEST OF 'THE ARAB HORSE}

ly mine, an Oregon make with the latest cowboy seat. I drew them a picture, showing what the horn was for, and after that. wherever we went the first thing they wanted me to do was to draw the picture of the cowboy throwing the steer.

Soon after meeting Akmet Haffez I had told him that I was not a government buyer and, indeed was not a rich man. I made it clear to him that while I was prepared to pay good honest prices and did not propose to "jew" anybody down, still I did not intend to be cheated. Government agents do not have to be particular about prices and consequently the Anezeh have been spoiled. The money values they set on their horses are sometimes astonishing, considering what labor in the desert is worth.

My old friend put his arm around my shoulders and told me that he would tell everybody we met and everybody whose horses we cared to see, that, unless they thought enough of him, Akmet Haffez and his friendship to sell on reasonable terms, we would buy no horses at all. And this he did in a speech to the great throng of Bedouins present. I had come there, he declared, to study the Arab horse in [110] 


\section{THE FEAS'T WITH THE ANEZEH}

his purity; that I was making pictures of him as they had seen and that I was going to write of his greatness.

"I have presented to this man," cried the chief eloquently, "the great war mare which came to me from your great Sheikh, IIashem

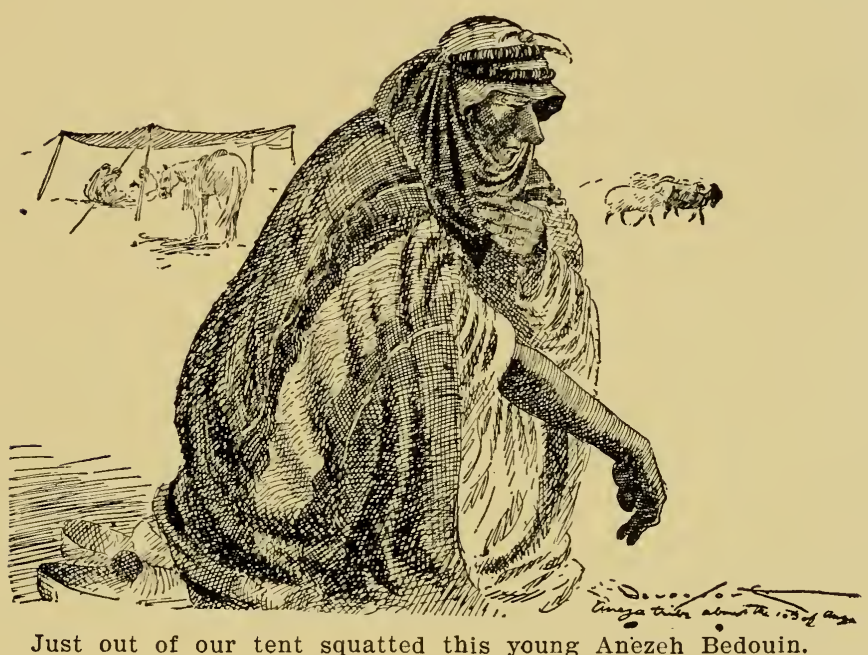

Bey. You know, as all Bedouins know, that no European could have purchased that mare at any price (and here all his auditors grunted their assent), but I have given to him the mare Wadduda, whose name means love and affection, and under that name I have given her to

[111] 


\section{MY QUES'T OF 'THE ARAB HORSE}

this man that she may be a living witness of the affection for him, not only of myself but of the whole Anezeh tribe. And in Aleppo the Governor gave to him the Maneghi Sheyel stallion, the 'Pride of the Desert.' So now treat the man as you would one of your own tribe. Those of you who have for sale horses that are 'Chubby'* he will talk with, but other horses need not be shown. Let it be a matter of your personal pride that he takes from the desert only such horses and mares as the Anezeh themselves would want to have-not meaning only such animals as the European governments would use."

Notwithstanding the friendship that had been shown to us by everybody, there was considerable disappointment among the Bedouins at Akmet Haffez's strict order. As Arthur and Jack remarked, it bound their hands so that they could do no "gouging."

The first horse was brought for inspection by a very old Bedouin. The animal was a dark iron gray stallion, five years old, a Kehilan Ajuz, the breed from which all other Kehilans are off-shoots, and which is considered the best of all the Kehilans. This young horse

\footnotetext{
*"Chubby," meaning "used for breeding purposes."
}

[112] 


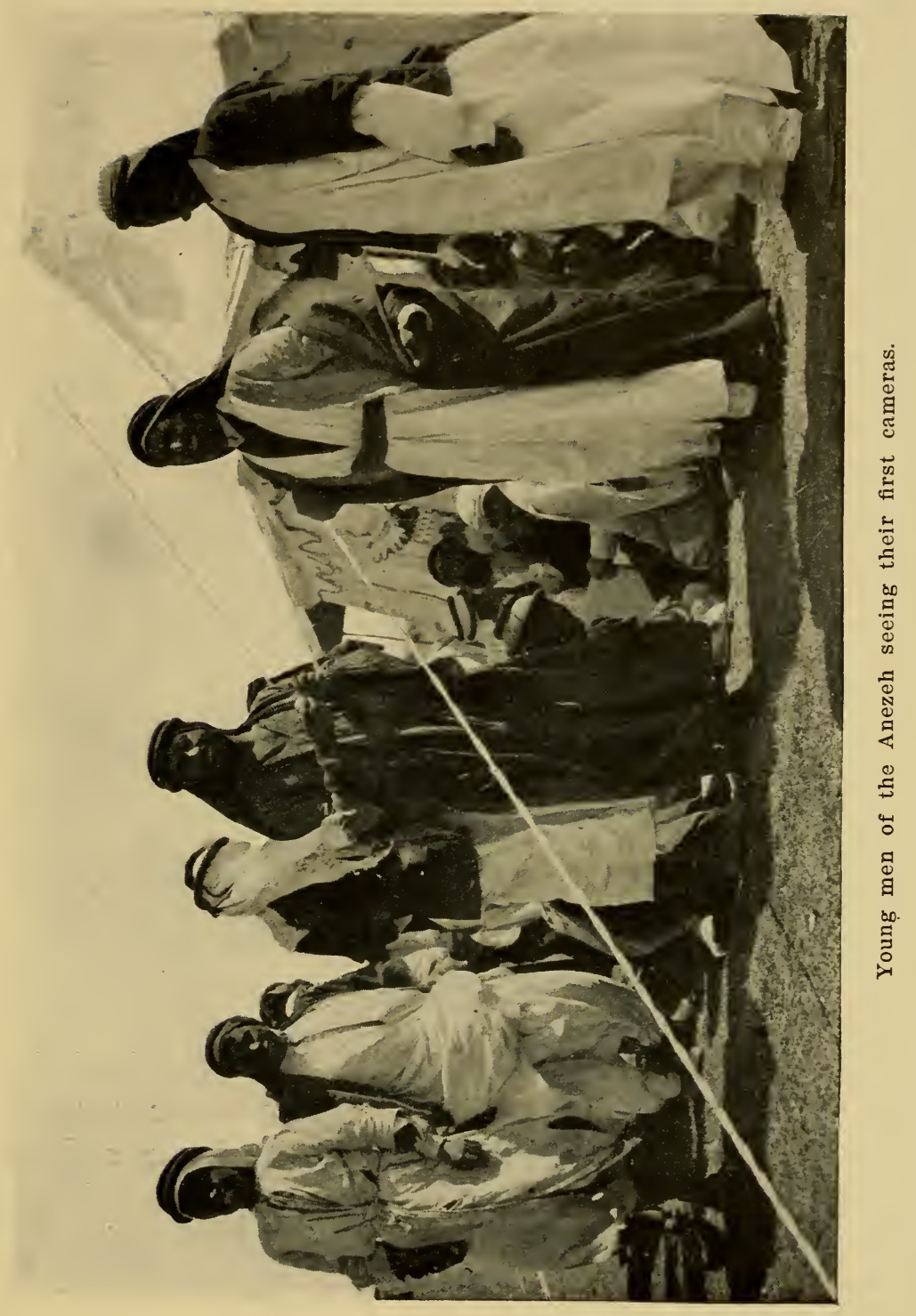




\section{MY QUEST OF THE ARAB HORSE}

was a powerful animal, but he had been in war evidently while very young, and so had a few bad splints. I was afraid to take him. When I asked to see him gallop, his owner, the old Bedouin, a small man far under the average height, riding a saddle without stirrips, flung himself on the horse like an animal and galloped over the rocky ground in a big circle. The horse was all action and held his tail high. The faster the horse moved the better he went, and I found it hard, though it had to be done, to refuse him just because of a few splints.

When horses were brought for us to inspect, Akmet Haffez told me not to seem overpleased, no matter how beautiful the animal was. If, after I had looked a horse over and decided that I wanted him, I was to wink at him and then, if the horse could be bought under our conditions and no others, he would get him.

When the Bedouins were showing a horse, or mare, it was quite a relief to see an animal, where the defects, if any, were never concealed. They just brought the horse and squatted down by him. No attempt was made to straighten his mane. If he had a blemish, 


\section{THE FEAST WITH THE ANEZEH}

they were more than likely to back him up to you so the blemish was the first thing you saw.

All young horses which were brought, Haffez measured from the centre of the knee joint to the hair line of the hoof, and applied that measurement four times in the direction of the horse's withers, to see how much more it would grow, if any. While the Bedouins consider a horse over fifteen hands high inferior to one under fifteen hands, I told them that if possible, I wanted to get large animals as people in America preferred size.

On the second day, a light gray horse colt, four years old, was shown. He had been bred by Sheikh Ali and was a Seglawi Obeyran. His dam was one of the favorite war mares of Hashem Bey and his sire was an Abeyan Sherrak. Sheikh Ali, Akmet Haffez, Ameene, the interpreter, and myself took seats on the ground and while the other Bedouins kept away from us we bargained for him. Sheikh Ali thought that owing to the animal's distinguished dam he ought to have more money than $\mathrm{Haffez}$ was willing to pay. I was afraid that Haffez was drawing a line so fine that we would make enemies in the desert, where I wanted only friends. After a [115] 


\section{MY QUEST OF 'THE ARAB HORSE}

long argument, Haffez got up and went away. Sheikh Ali followed him, and Haffez, turning, extended his hand, but the other Sheikh would not take it. I asked the interpreter what they meant and he told me that Akmet Haffez did not believe the price asked for the horse was a true estimate of their friendship, and that the other man insisted that Haffez,

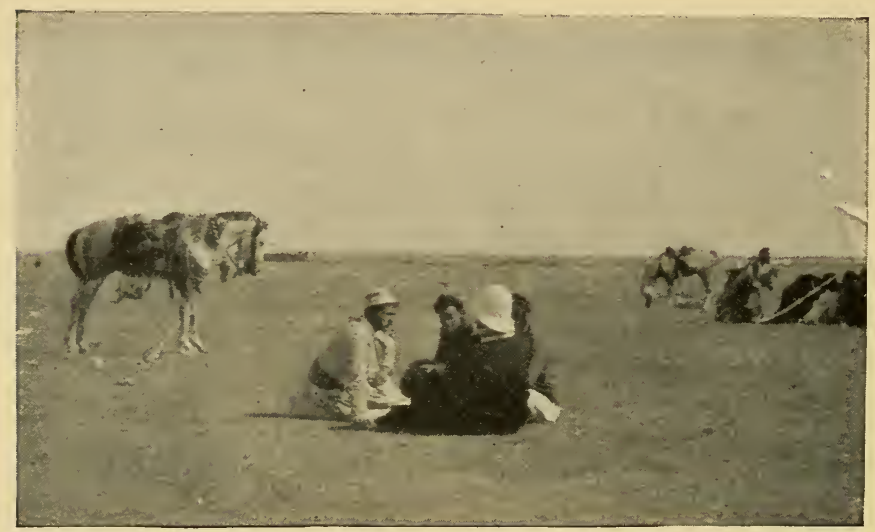

The method of buying a horse in the Desert. Purchasing Azra, a four-year-old Seglawie Obeyran.

who had not been to the desert for many years, was ignorant of the recent prices which the Anezeh had been getting for horses. Haffez had replied that he knew the price that every horse had brought and that on the price of [116] 


\section{THE FEAS'T WI'TH THE ANEZEH}

every horse sold out of the desert, he, in Aleppo, got a commission of five pounds, just as Hashem Bey, the Sheikh of the Anezeh did. On this occasion he said he was not taking any commission, and that he would not allow me to buy any horse except at a fair price.

We three Americans were astonished at this performance, and so was Ameene. The latter had seen the miserable gang of cut-throats around Beyrout that were trying to sell us horses whose most exaggerated value would have been about two pounds. Truly we were in safe hands in the desert.

When I heard that there was only $\$ 20$ difference between Akmet Haffez and Sheikh Ali on the price of the gray, I told Haffez that we were to be the guests of Sheikh Ali for three days, and, as he would then have to feed all our horses, camels and men I would like to buy the horse, even against Haffez's will. So I bought him. As I rode home, we found out, as Akmet Haffez told us before we left Aleppo, that the poorest horse we had, I had bought against his wishes.

Late that afternoon a man came riding a remarkable gray mare. She looked so different from the other mares that I could hardly wait [117] 


\section{MY QUEST OF 'THE ARAB HORSE}

for Haffez. When I asked if she was "Chubby," the Bedouin smiled, and almost laughed, when he said "Kehilan Ajuz," which is equivalent to saying, "Rather, she's the dam of all that is chubby."

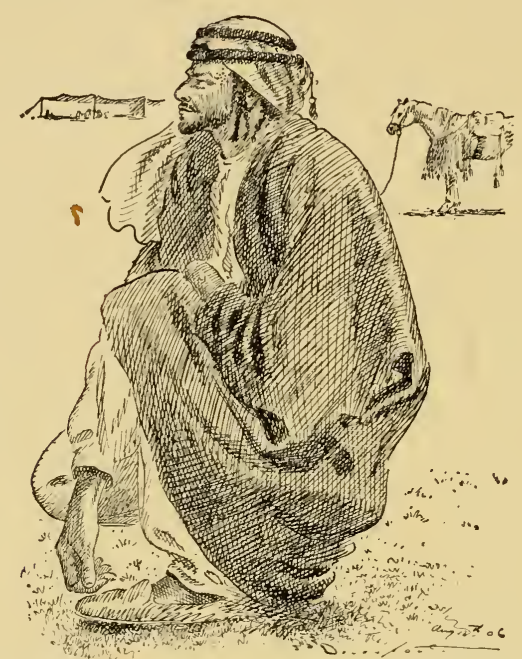

A Gomussa Bedouin of the Sabba Anezeh, showing the artistic tattooing at the corners of his eyes and the braids called the "love locks."

She was a picture, though she had no jibbah, or bulging forehead. On the contrary her forehead was as flat as a board, but her eyes were far apart and set in the peculiar Japanese slant. They were turned up at the outer corners like those of a chorus-girl with a 1907 [118 ] 


\section{THE FEAST WITH THE ANEZEH}

make-up. There was the same stately dignity about her that Wadduda had; she looked like a fine lady of quality in the presence of a lot of cooks at an employment agency. In my efforts to buy her, before Haffez got out of the tent, the Bedouin smiled and laughed, and, when Haffez came out, without looking to see who was on her back, he too began to roll with laughter. Then he looked at me as if urging me on to buy her quick. Ameene began to laugh, too, and finally explained that the joke was on me. The mare it seems could not be sold. She was famous from Nejd to Aleppo, and was owned on shares by the Anezeh. She had been ridden over simply to find out if we would like to look at her last son, a colt two years old. I asked if we could not break the rule and still buy her, and all I got was another laugh.

Neither the mare nor any of her daughters could be sold, and all in the female line were retained by the Anezeh. At that time she was twelve years old and looked four. When she was seven or eight years old she had swept the desert for speed. Six years before the German Government had paid four hundred pounds for her three-year-old son. We stood

[ 119 ] 


\section{MY QUEST OF THE ARAB HORSE}

immovable as she was galloped away to fetch the colt which we were to see, and which I had already made up my mind to buy, no matter if his legs were crooked.

It was nearly sun-down when the same Bedouins returned riding the colt, and, when he was a hundred yards away, Thompson, Moore and myself, all remarked that anyone could tell who his mother was for his eyes were set in the same peculiar manner. It was evident from our measurement that he was not going to be as big as his mother, but that he showed the same characteristics was enough. He was absolutely free from blemish of any kind. He was a pink gray that would probably shed out into white; his disposition was as perfect as his mother's and, although a scant two years old, his manners were those of a little gentleman, and we came to terms rather quickly. When a price was finally agreed upon, Haffez always called me and the Bedouin to him. Taking the right hand of each of us, he would join them; then laying one of his hands over ours and pointing up, he would ask the Bedouin if he would swear before God that everything he said was true, and if he would be willing, with God as a witness, to ask the

[120] 


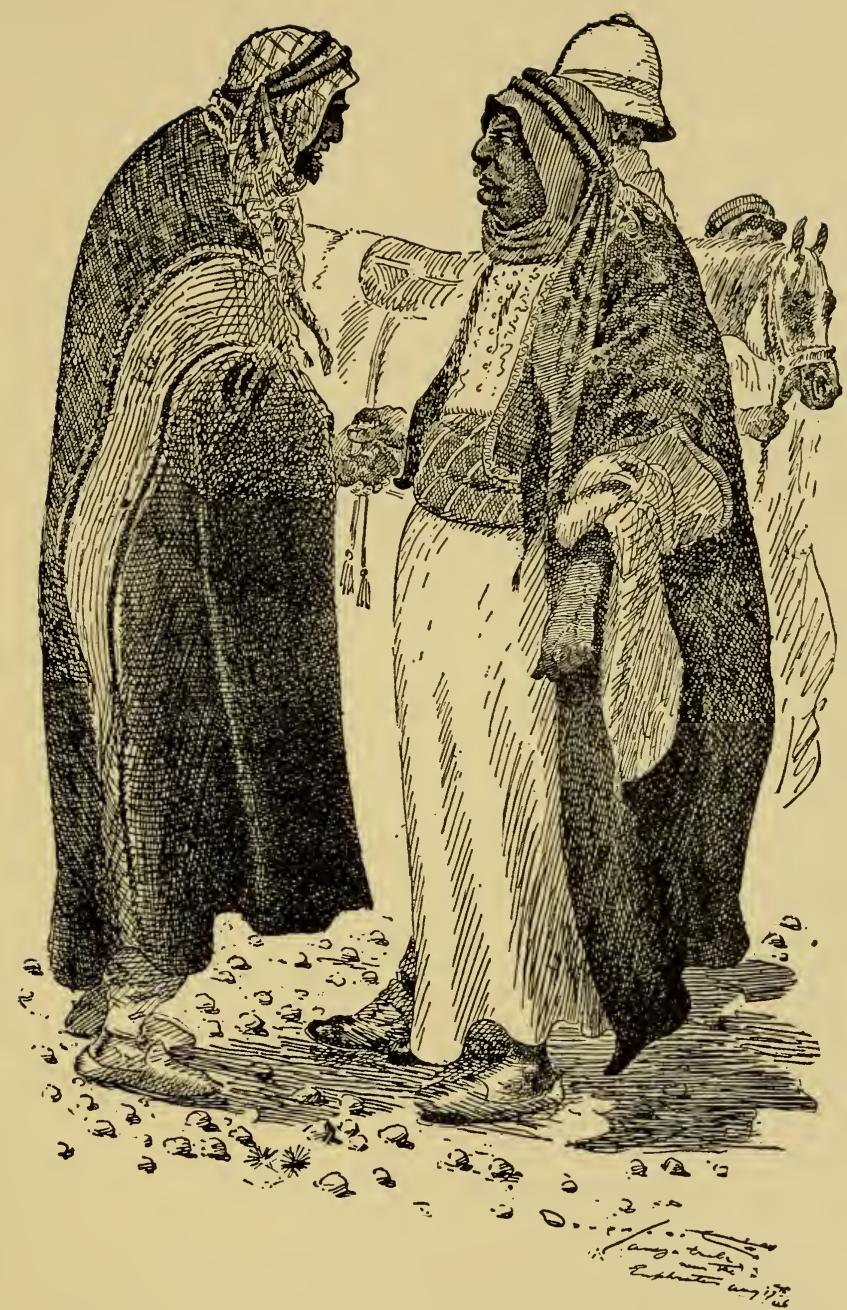

Achmet Haffez would join our hands just before the horse was bought, then resting his hands on ours, would ask the warrior to repeat to God all he had just said about the animal, then with a toss of our hands the deal was closed. 


\section{MY QUEST OF THE ARAB HORSE}

Sheikh of the tribe to put his seal on the bargain. Then if the Bedouin said yes, Haffez would toss the hands up and the deal was closed. We felt exceedingly proud of this two-year-old. The Bedouins came and sat round him in honor of his distinguished mother.

Later Arthur and Jack had a laugh on me. We saw a bay mare galloping at some distance and her action impressed us all, but me especially. As the rider came closer the others said the mare was limping, but I was doubtful. She moved so well that I had hopes of buying her if she filled Haffez's measure. But to our astonishment when she came walking up we found that one of her pasterns had been broken. She was walking on the ankle joint, the foot a withered-up dried object, being turned up at the outer side like that of a dead horse. We learned she had been injured in war and that the accident only hindered her speed a little. 


\section{CHAPTER X}

AN IMPORTANT CEREMIONY IN WHICH I WAS ONE OF THE PRINCIPALS-A CIRCASSIAN VILLAGE WITH A VISIT TO THE GOVERNOR AND WHAT BEFELL SHEIKH ALI

Arthur Moore, riding Akmet Haffez's Abeyeh Sherrakieh mare, an animal with a wonderful head and build, was to go back to Aleppo at this time with Jack Thompson and Faiot, Haffez's younger son, to procure more tea, of which the Bedouins were very fond. Indeed we had used up nearly all we had brought out for the entire trip, in our first three days at the camp. He was also going to bring some more gold, and his Mauser rifle. We were nine hours ride, about thirty-five or thirty-six miles from Aleppo, and while my companions were gone I tried to come to an agreement with Haffez orer the mare which Moore was riding. She had been taken in war by the Anezeh, from the Shammar, across the Euphrates, and her pedigree bore the last seal [123] 


\section{MY QUEST OF THE ARAB HORSE}

of Sheikh Faris, the great enemy of the Anezeh, who had been dead two years. She was small, not more than fourteen hands two inches high, but I never saw such beautiful hind quarters and back tendons on anything in horse flesh.

Now every time I had tried to buy this mare from Haffez he turned it off with a joke, saying that everything he had was mine and that there was nothing to buy. Then when he would apparently talk seriously about selling her, he would warn me to be careful for the agreement he had made with the Anezeh was

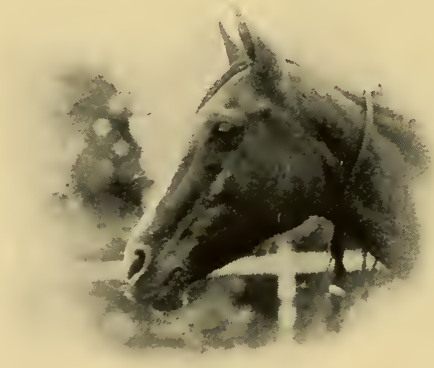

ABEYAH

This mare's head was considered by the Bedouins the most perfect of the Anezeh.

not binding between us, and that he would dicker and bargain as best we could. Even when I consented and asked him to put a

[124] 


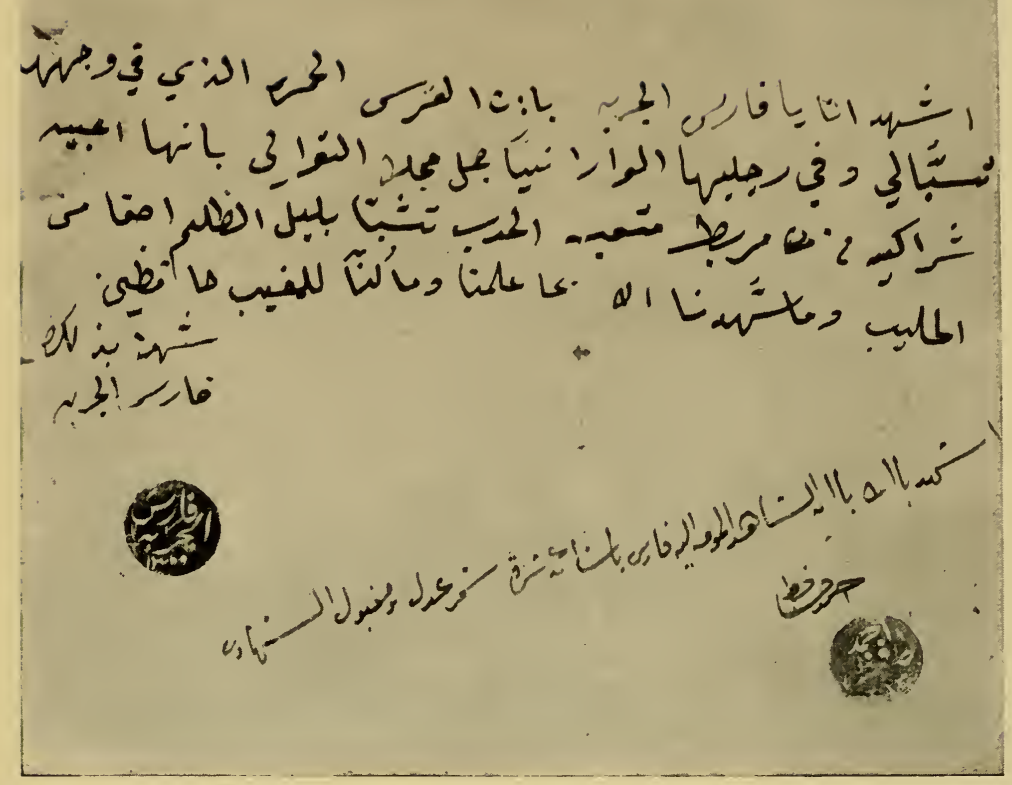

Abeyah's pedigree bearing the last seal of Fares (the dark one).

I, Fares El-Jarbah, hereby testify that the red mare which has white on its face and on its long hind legs, is Abeyah Shrakieh of the breed of Mathaba El-Hadab. She was bred in the darkness of night and is purer than milk. And we have not testified except to what we have known, and we are unaware of the unknown.

Witness thereof: FARES EL-Jarbah.

ATTESTATION:

I testify by Allah that the aforementioned witness, Fares Basha Ibn Atrat, is a rock of truth, and his testimony is acceptable.

(Signed) AhMAD HAFEz. 


\section{MY QUEST OF THE ARAB HORSE}

price on her, he said ten pounds, and that threw the whole thing back into the joke basket. But that night I finally got him. I told him seriously that above all the mares I had seen on the desert, I wanted his Abeyeh Sherrakieh, because of her fine head. So he finally set a price which seemed reasonable, and I offered him ten pounds more and made him take it. I also bought his Hamdanieh Simrieh filly, four years old, a bay, which he himself rode. I think she can outwalk anything in horse flesh I ever saw, and I believe that even in a field of exceptionally fast walking horses, she would be five miles ahead of the lot in an all-day walk. She and her sister, with a broken shoulder, were the only Hamdanieh Simrieh in the northern part of the desert. The Anezeh told me there were some in the Shammar, but only a few. They are the rarest horses in the desert, and the blood is held in higher esteem than anything else.

I hope I have succeeded in impressing the reader with the very fine nobility of character of Akmet Haffez. My friendship with him and my admiration for him began at our first meeting in Aleppo and each day made both stronger. And now I was to come into closer

[126] 


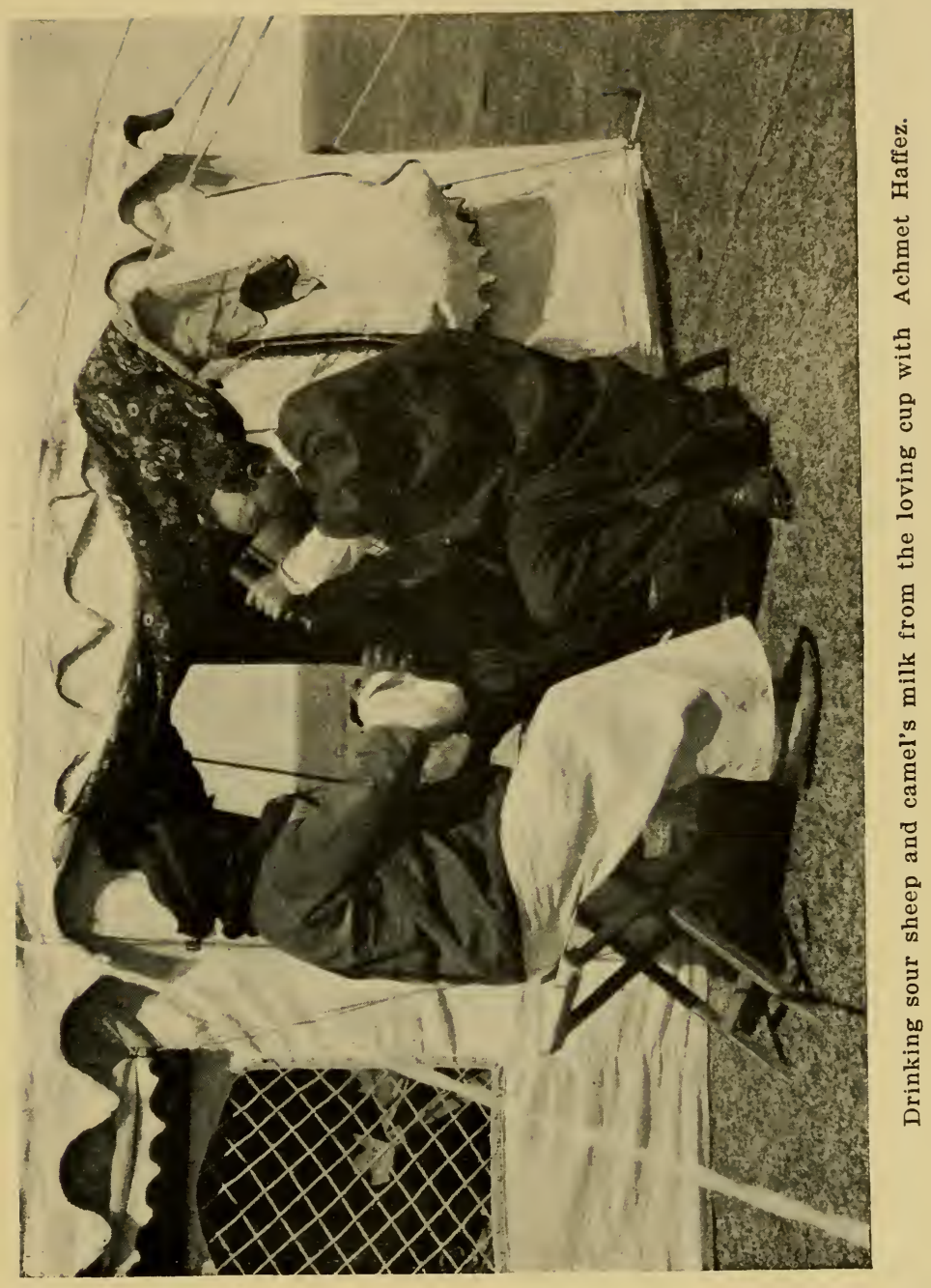




\section{MY QUEST OF THE ARAB HORSE}

relations with him. The morning after the mare became mine we were to start on the visit to Sheikh Ali and just before we mounted I went through the ceremony which made me his brother.

Neither of us had brothers and so we agreed to follow out our old custom of the Bedouins and take the fraternal pledge. I first treated the matter a little too frivolously, but the Bedouins were very solemn.

Standing at one side of the tent, in the presence of many witnesses, we held up our right hands and, with our left clasped together, repeated the pledge. Akmet Haffez began with the words, "Wallah! Wallahi!" ("O God! My God!") which I repeated after him. "Wallah! Wallahi!" and then together we said them over and over again.

"Billah! Billahi! Tillah! Tillahi!" chanted the old Bedouin. "Akhwan, akhwan, el yom wa bookra wa l'al abad, akhwan." ("By God and through God, brothers, to-day and to-morrow and forever brothers!")

I felt nothing of frivolity now and as I grasped his hand and took the oath my eyes were moist. After it was over he asked how I felt now that I was the brother of a brown 


\section{AN IMPORTAN'T CEREMONY}

old man, who ate with his hands. I replied that I felt no change; that we had apparently always been brothers, whereupon he began to cry.

Who knew, he asked, but that we had been through a similar ceremony that God himself had performed centuries ago on some other planet.

Shortly after, we started for Sheikh Ali's tribe, the A bogonese, a branch of the Anezeh, who seldom go far south in the Sheikh Ali Rashid of the Abo-Gomese, go far south in the $\begin{gathered}\text { a sub-tribe of the Anezeh. } \\ \text { a }\end{gathered}$ desert.

Sheikh Ali greeted us warmly and accompanied us on a ten-hour night ride to a Circassian village near the Euphrates, to see a gray colt, a Kehilan Jilfan Stam el Bulada, a young horse whose dam was a distinguished war mare. This ride on a hot night was very trying, but the Bedouins beguiled the time with the melancholy song so common among them and with many curious questions about America.

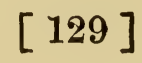




\section{MY QUEST OF THE ARAB HORSE}

The shooting stars which fell in every direction in the desert heavens, were playing like Pain's fireworks, but I was so tired and sleepy that it was with difficulty that I kept awake. About three in the morning we stopped at a small village consisting of a dozen houses. The villagers were aroused by a barking of the dogs and when they heard the words, "Akmet Haffez!" they got up instantly and made us welcome, and we slept in the beds they had just quitted, till about five o'clock, when we started on again. About ten the next morning we arrived at the Circassian village, and after seeing the colt and having had a few more hours' rest, we felt well repaid for the trip and bought the horse as well as a bay colt with a peculiar dark brown spot on his right flank-a Maneghi Hedruj. At the same place we secured a chestnut two-year-old, an Abeyan Sherrak, which had been recently brought from Deyr, on the lower Euphrates. This little fellow was so full of life that they had to show him with all four feet hobbled, but he understood the hobbles so well that in his pacing motion he managed to make much play. All these three colts were bred by the Anezeh.

While at this village we saw a gray mare, [130] 


\section{AN IMPORTAN'T CEREMONY}

four years old, that stood fifteen hands and two inches high, which I wanted to buy very much; but she was not "Chubby" and $\mathrm{H}$ a ff e z thought the asking price was too large, so we didn't get her. At this same village, a Circassian came along with a beautiful filly. Whenever I approached her she would stamp as a sheep does at a strange dog, turn and try to kick me-anything to keep me away. I asked the Circassion if she was "Chubby," and he told me "Yes." When Haffez came out, he said "Chubby?" and the Circassian told him "Yes."

I saw a Bedouin whisper to Haffez, and the latter ran over and gripped the Circassian by the right

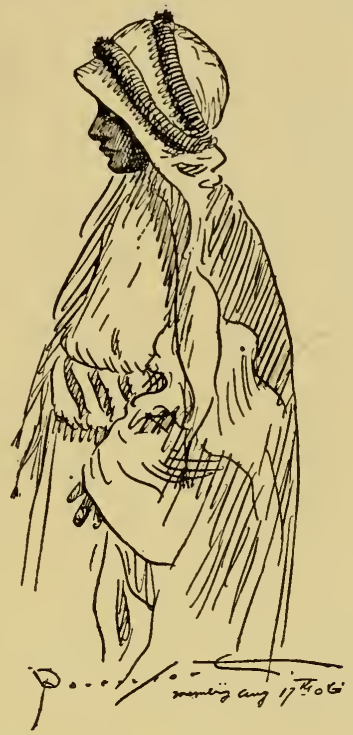

This handsome Bedouin boy who had come from quite a distance with his father to bring a dark iron-grey horse of the family. of Jelfon Stam-elBulad. The boy stood with fingers spread looking with awe and astonishment at my Oregonmade saddle that lay on ground.

hand, and asked him to say to God that she was "Chubby." If you ever saw a fellow pull loose quick, it was this Circassian. He yelled [131] 


\section{MY QUEST OF THE ARAB HORSE}

in his efforts to get away, and at the same time saying the mare was "Chubby" to me, but not to God.

It was such a hot day that we had not gone out of the house except to look at colts. Finally a messenger came from the Governor's office, saying that his Excellency was much put out, as he had been sitting at his office in state, ready to receive us, for the last two or three hours, and that he was anxious that we should call on him, in order that he could return our visit. So with Akmet Haffez and Sheikh Ali, we went through the blinding heat to the old rock-and-mud-built Governor's Palace.

We were ushered in and passed the bodyguard of the Governor, which consisted of an Arab with a spear, a soldier with an old-fashioned gun, and another man with a sort of a tomahawk. The Governor had a very long and narrow face, with a small black chin beard. He wore a fez and nervously counted beads, much irritated at his servants because of the irregular way they served the coffee and cigarettes. He kept Ameene, the interpreter, busy, for he wished to know all about us-from where we had come and when we were going. After I had made a bluff at 


\section{AN IMPORTAN'T CEREMONY}

smoking fifty cigarettes, and drinking as many cups of coffee, we were served with some of that red sticky lemonade, or syrup, which seemed to completely close our throats.

All this time the Governor sat on an old dais, trying so hard to be dignified that it was almost humorous. A row of men against the opposite wall of the room seemed to be members of his cabinet, or advisory board, and they were mostly very fat men.

As we started to leave one of the fat men whispered something to Sheikh Ali, and after we were outside I noticed that the big handsome Sheikh had been detained. Haffez came to me with a peculiar twinkle in his eye and told me that apparently we had gotten into a queer situation. Sheikh Ali, it seems, had been "wanted" for murder in Membig for a number of years, and as this was the first time he had been to the town for more than eight years, he had been detained. Haffez wanted me to go back to the Governor and tell him that as Sheikh Ali was my guest it would not be fair to arrest him now. In other words I was to inform his Excellency that his fingers were crossed and that he ought to turn Ali 


\section{MY QUEST OF THE ARAB HORSE}

loose. After I had gone, if they could take him, well and good.

I was getting ready to go to the Governor's office and spring the speech, when Ali himself came out with a broad grin, saying that the Governor had let him off from the murder provided he resumed paying his camel tax, which had been overlooked since the murder was committed. We had hardly stopped laughing and gotten back to our own quarters, when an excited servant came dashing ahead to clear the way and to tell us that the Governor was about to repay our visit.

When the Governor came, after the usual rush of coffee and cigarettes, we had rather a pleasant visit and talked as if we had not seen each other five minutes before. He was much interested in America and its political customs. At the request of Akmet Haffez, I told him some Silverton stories. He was more than interested in my father and requested to be informed of the latter's health as soon as I returned to America. There was no more talk of Sheikh Ali's crime and I have often wondered whether he is paying those camel taxes! 


\section{CHAPTER XI}

AS TO DOGS ; AND AS TO ONE DOG IN PARTICULAR.

THis chapter is going to be a digression. I am going to let horses go by for the moment and talk about something else. So you have fair warning to skip the chapter and catch up further on. But after all, my present text is "dog"; and if you are truly a horse-lover you must almost always necessarily be a dog-lover. The two things somehow go together.

Besides, although the rather involved story I am about to relate, began in Morris Plains, N. J., and was continued in Paris, Constantinople and Aleppo, it ended in the desert and on the way to visit the Sheikh Ali, of which I told in the last chapter. That is my excuse to you for telling it at all. To myself I do not have to make any excuse of any kind-I just simply have to tell the story. And here it is for what it is worth:

When I left Morris Plains I wanted to take

[135] 


\section{MY QUES'T OF THE ARAB HORSE}

with me two worthy Airedale terriers that were more or less (rather more) members of the family. Instantly there went up from the human part of the household, a wail that the dogs would be in the way. One of the dogs had been on a trip as far as Oregon, and had never been in the way; but as this wail went up from everybody who was not in the least concerned in the matter, and notwithstanding that the dogs wanted to go, I chucked the plan. I hated to leave them, for a dog's love in a strange place is comforting, and these two dogs I had known from puppies, and they knew me. But they were left behind and not even allowed to say good-bye to me at the station, and after that, they were forgotten for a time at least.

On the voyage to Havre we met a traveller, an Englishman, of course, who had lived and hunted everywhere, and who insisted at every point in the conversation "that on the Euphrates River, one always needed a dog." That was enough; I am not a hunter, but I was pining for an excuse to get a dog. So, at Paris, the first thing I inquired for was a dog shop which had for sale the right kind of a dog. Mile after mile I rode in taximeters and [136] 


\section{AS TO DOGS}

borrowed autos, always hunting dogs, and at the last moment I got on the track of a shop and such a dog as I described; a dog that would be a companion, a hunter, and above all a friend. But we had little time left in which to buy a dog.

We were actually on the way to catch the Orient express for Constantinople before we got a chance to go to this particular dog shop. A woman ran it; a dark-complexioned woman, with black hair which was exquisitely smooth. She showed the dog; it was a large black-andtan with a bobtail-a restless sort of cur which she declared was a sheep-dog. Anyway, she called it something in French, which Moore said meant "sheep-dog." We didn't believe Moore in the least on principle, but we believed the woman. She was so attractive that we hardly saw the dog, and when she made eyes at us we realized only one thing and that was that she would have made a fortune in a New York dog store-or almost any other kind of a store.

So we bought the dog. We didn't like him, but we bought him just the same on her guarantee that he would be a charming companion. That seemed enough at the time. On the train 


\section{MY QUES'T OF THE ARAB HORSE}

he was nervous and wanted to get away from me. He seemed to be everybody's dog but mine. When we arrived at Constantinople he and I were as distant as ever, and at Beyrout it was the same. Wherever we stopped he recognized that I was in the party, but that he was not mine. He was more of a nuisance than a dog. He did not have anything to recommend him, not even manners. About the only comfort any of us could get out of him was that his sight recalled the lady who sold him to us, and in that way we coaxed ourselves into the belief that we had already got the $\$ 25$ worth out of him. Long before we arrived at Aleppo I began to show the strain, and at Aleppo, after I had carted him over three thousand miles, I left him in a boarding house, while I went to the desert alone.

As I rode out at the head of the caravan in search of the Anezeh tribe, I realized that for weeks (they would seem years of care and patience with a wayward dog) I was to be without even him, but comforted myself with the fact that, as we evidently did not understand each other's language, it was best we parted. I had named him (the only French word I had been able to learn) "Dedong" (Dis [ 138 ] 


\section{AS TO DOGS}

donc!), which translated means "Say!" You ought to have heard the Frenchwoman say that.

But we had not ridden far into the desert before I missed something. I kept looking down and behind me to see if something were not following me. I could not quite make out at first what it was I missed, but I knew that something was lacking.

The red and yellow soil of the desert seemed to change into green grass and greener trees and I could see the rich New Jersey landscape stretch away before me. I was in the desert and in Morris Plains at the same time. I grew homesick. Hark! Was that a familiar bark or just the echo of something I wanted to hear? Then I knew that what I missed most was the companionship of a dog. I thought at first, of course, of the Airedales that wanted to make the journey with me and I felt more homesick than ever. I longed even for a sight of "Dedong." I was sorry that he had been left behind and that I had ever regarded him with disfavor.

Even the excitement of the first night in the desert was of little consolation. We had been received with great ceremony and all that the 


\section{MY QUEST OF THE ARAB HORSE}

Anezeh had was ours, but although I had been tremendously impressed, it was not until the second night that I began to feel really at home. On that second night I saw some dogs. Our tents were pitched in a beautiful spot, and as the Bedouins were walking about gossiping of the new arrivals, I noticed how different the dogs were from the mangy curs we had seen in every village and town from Constantinople to Aleppo. While almost wild, they were large and noble-looking fellows, with big heads, and were accustomed to drive flocks and herds. They didn't roam promiscuously like the dogs of the town.

I saw at one tent a litter of pups that were big and husky. This dog family consisted of the father and mother and four children-three girls and a boy. The boy walked out to see us. I stopped and patted him, whereupon he fell on his back with his heels up, and was immensely pleased.

He looked back at the tent where his family was and wondered if they were as happy as he. He saw in his home a place where only the fittest or the prettiest survived. His father was a big powerful fellow in his prime, and he would be able to drive the males from a good

[140] 


\section{AS TO DOGS}

many litters before one would eventually whip him. The sisters were pretty, and could stay at home, but for this big overgrown puppy there was not much of a future with his father. $\mathrm{He}$ was so big for his age that his father snarled at him, and the neighbor's' dogs made him keep out of their tents. The only kindness he got was from his mother. He was well fed, but he was waiting for an opportunity. $\mathrm{He}$ wanted a home of his own.

I stopped again and he came to me and that time we knew each other a little better. He was still as bashful as most pups who have not shed their first teeth, but as we finally parted, I saw him look at me long and hopefully. He seemed to tell me that he was a boy with a purpose in life, whose father didn't understand him; that while it was customary for a boy to stay at home and work till he was twenty-one years old, in his case he would have to begin to do something when he was twelve or fourteen, owing to the determined nature and unkindly ways of his parent.

That evening after the Bedouins had gone, a big white baby head shoved its way through the curtain of my tent. The pup was returning my visit in true Bedouin fashion. He did 


\section{MY QUEST OF THE ARAB HORSE}

not walk; he crawled with politeness. After a few moments taken up in patting him, we went to the cook's tent and got better acquainted with the aid of some chicken bones. I left him for the night, but heard him barking at the camels as they came by about midnight. The next morning he was there; his opportunity had come and he had taken it.

He had filled the only vacancy, perhaps, on the great Arabian desert from Nejd to Aleppo. There was probably not a tent, except mine, that was not carefully watched by many dogs. His tail was poised in a different way. $\mathrm{He}$ had actually grown during the night, and he had the ways of a full-fledged dog, and wouldn't let others come around. He watched the saddle, and lying on the saddle blankets, with his big brown eyes wide open, he was thinking how to manage his empire. All day he went from tent to tent, from saddle to horse, as if the weight of the whole caravan was on his shoulders.

He was no longer a bashful puppy. $\mathrm{He}$ growled and barked when his father and mother drove a hundred sheep too close to his pre-empted home. He wouldn't even let his sisters, who were as dainty as girl puppies 


\section{AS TO DOGS}

could be, sniff around the tent. They were not afraid of him at first, but after he had really bitten them, they retreated from his territory and watched him with their heads tipped to one side. He sat at our tent pegs, and seeing life seriously was brave enough to tackle it. His hour had arrived and he was there with all his four feet-and those feet were the only things that were holding him back. They looked like a composite picture of all the babies' feet in the world. They were heavy and cumbersome, but he had not lost faith in them. It was strange, but you could actually see him grow. We laughed when we saw, an hour afterwards, that his tail was an inch longer, held higher up and showing more independence. The last thing that night he was walking among the stallions and mares with an important air that nearly threw his shoulder-blades out of socket. During the night I heard him several times; his growl was coarser and he made several tours to see that everything was all right.

At six in the morning he came to me, as much as to say: "These donkeys and sheep and camels think that, because they have known me

[143] 


\section{MY QUEST OF THE ARAB HORSE}

all my life, they can walk right over our tent ropes, but I won't have it."

He kept up this attitude, getting more and more confidence in himself, until we were ready to start on our visit to Sheikh Ali. I had wanted to take him along, especially when he was mouthing over my hands with his sharp baby teeth, but his big soft feet and legs looked too young to stand such a march, and I gave up the notion altogether. But the pup had other ideas. We were a half mile or more on our way when Ameene called to me to look in the shadow of my horse, and there almost under my stirrup was the pup, lumbering along. His tail was rolled up more importantly than ever. At last he had a mission. He had seen that we were without a guard, so he had cast his lot with ours. He recognized that we needed protection and he was giving it at the cost of leaving home and a good mother, and a father who was compelled to remain behind by the laws of home, to be what he was. I could not keep my eyes from him, he was so brave. He was now out of sight of the environment that he knew and was going to the big desert. At intervals he sniffed at my stirrup as if traveling was new to him. He was a pioneer without [144] 


\section{AS TO DOGS}

practice, and he did not propose to get lost. He proposed to stick by me.

I thought of Senator Vest's remarks when he appeared in court at St. Louis for a tramp whose dog was killed by a neighbor. Vest spoke of one's children and how, no matter with what tender kindness and care they were reared, they would leave home and parents often without a farewell.

But there was one friend of man, said the Senator, who never deserted him; a friend who would lick the hand that had no food to offer; a friend who, when death came, when the master had finished his life, when all others had returned from the graveyard, would mourn at the grave itself--his last, his best friend, his $\operatorname{dog}$ ! I thought of that and then of this puppy, a little fellow offering his devotion for my friendship and at that moment giving me a friendly glance from his eyes. He was like Jefferson C. James, who once ran for Mayor in San Francisco, and who said in a somewhat famous speech: "I seen my duty and I done it." James was not elected, but that has nothing to do with this pup.

We followed Sheikh Ali and Akmet Haffez across the plains for miles. We saw a rab[ 145 ] 


\section{MY QUEST OF THE ARAB HORSE}

bit; it was the dog's first, and he fell over a clod in his initial race. He came back to the shadow of the horse, and there ambled along in a dignified way. Astride the best horse in the desert, and protected by the best puppy in the world, I was much elated. We flushed some francolins, beautiful birds, but he was too important to be a bird dog. He was marching among horses and men and camels. $\mathrm{He}$ was the only dog in the caravan and at every mile he seemed to realize the fact more. $\mathrm{He}$ was avoiding the camel thistles as best he could, but while more francolins went up and his attention was on them for a moment he got a nasty burr in his big soft foot. He went on three legs a while and then showed of what stuff he was made. He rolled on his back and deliberately gnawed the burr out with his teeth without a whimper. He had left mother and father for me, and he was to meet emergencies as they came.

He was going out where there was a future, and no such little thing as a thorn, not even a camel thistle, could stop him. I wondered if he would be happier if he knew of the glittering collar I was going to get for him when [146] 


\section{AS TO DOGS}

we reached New York, and how proud I knew my own dogs would be to meet him. With the knowledge he would acquire on a trip to the Anezeh, everything seemed to be before him. Sheikh Ali had galloped his bay mare a mile ahead to the tents of his own tribe, and the horsemen came galloping to meet us, carrying spears that looked thirty feet long. It was all excitement and the puppy ran ahead to join it. We saw the Sheikh's tent, a big tent with lots of men near it. They were killing a lamb and wolf-like dogs were jumping around it. Before I could dismount, or a man come to the rescue with a spear, my volunteer baby guard, my puppy, my boy that was leaving home at ten and going out into the world to make a living, was torn and dead. He didn't whine. He had fought as well as he could with his puppy teeth, the teeth that had scratched my hand in play a few hours before, but they had failed him. He had started out for himself to be as much of a man as a dog can ever be. He had left home that his father might rule alone. But he was gone and it was all over! The opportunity we thought so bright was a blank. The career that had started so well had ended quickly. The first [147] 


\section{MY QUEST OF THE ARAB HORSE}

real fight he had ever made was the only one he ever was to make. He died a real hero.

I felt as if I could have destroyed the dogs of the desert for this wanton murder. The affection of this puppy was spontaneous and it was mine. There was no glittering collar on him as he died, but he died as he had traveled -in the shadow of the horse, before his master's eyes and without turning tail. 


\section{CHAPTER XII}

THE MEETING WITH HASHEM BEY, THE GREAT SHEIKH OF THE DESERT.

WITH that dog story off my mind (I simply had to tell it), the narrative of the trip may be resumed. We left the Circassian village at three in the afternoon and were back at our tent at five in the morning. For us the ride was tiresome, but the horses were as fresh as ever. This wonderful endurance of the Anezeh horses, although we expected much, was a constant surprise. They never seemed to tire and I shall relate soon a remarkable instance of their strength and stamina.

The event of importance to which we were now looking forward was the meeting with Hashem Bey, the Sheikh of Sheikhs of the desert. No sooner indeed had we arrived at our tents than we were informed that the ruler of the Anezeh had returned with a large number of his warriors to see us, and so after

[149] 


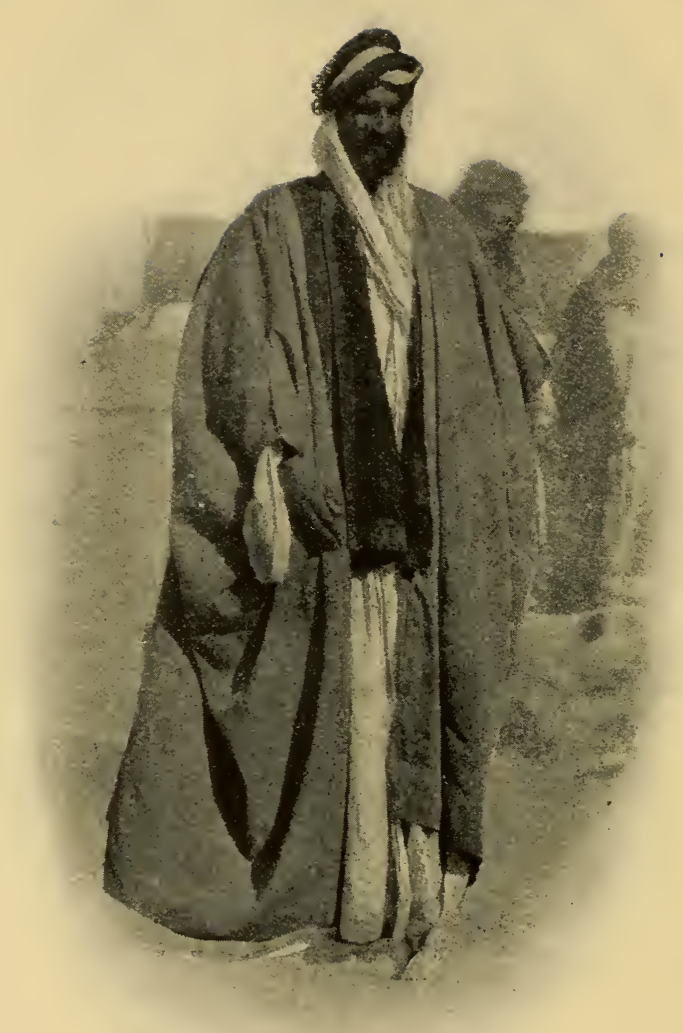

The Supreme Shiekh, Hashem Bey. 


\section{MEETING WITH HASHEM BEY}

a few hours' rest the meeting came about. Haffez walked over, with the Sheikh on his arm, and we met just outside of our own tents.

Hashem Bey was tall and thin, a young man of thirty-four, or even younger. $\mathrm{He}$ was strictly the war type; his eyes were set far back under the bones, without being wide apart. After we had talked for ten minutes and had assured him that it did not seem right that the greatest Sheikh in all the Syrian desert should have ridden a journey of three days to meet us, noticed that there was something lacking in him.

He was not the big man Akmet Haffez was. He did not possess the latter's fine sense of humor or, indeed, any sense of humor; he was without that indefinable air that immediately suggests gentility and good breeding. He was very evidently not particularly pleased to meet us and the reason for this soon came out. I had called his attention with a great deal of pride to the fact that $I$ was riding his brown Maneghi Sbeyel stallion, the pride of his entire people, and a present, by order of him, to the Governor of Aleppo, and the latter's present to me. His lip curled and he made that motion of his hands, slapping them past each [151] 


\section{MY QUEST OF THE ARAB HORSE}

other, common among the Bedouins, which meant that the horse was lost to them.

In all our subsequent intercourse this loss of the "Pride of the Desert" seemed uppermost in his thoughts and he never allowed us to forget that he was not pleased with the Governor of Aleppo. Be-

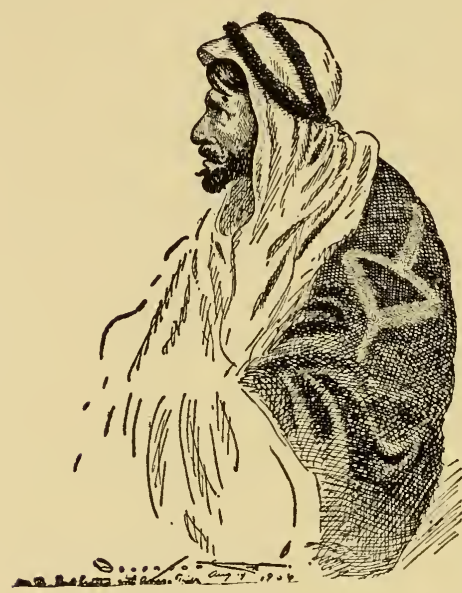

The Sheikh of all Sheikhs. fore the first interview was over I realized that we were a disappoint$\mathrm{ment}$ to each other, and was secretly glad I had not ridden three days to see him, as glad, I imagine, as he was sorry he had done so, though, of course, he was in duty bound to take the ride in honor of Akmet Haffez.

Perhaps, too, my dress had something to do with his disappointment. I was looking shopworn, to say the least, and he might have thought that I would be dressed like some of the foreign government army officials who 


\section{MEETING WITH HASHEM BEY}

often came to him to buy horses. We got along well, but never easily.

Finally I took a walk with Akmet Haffez, and when we were alone, except for Ameene, the interpreter, Haffez asked in a low voice how I liked the great Hashem Bey.

I looked at the old man's face to see if he was prepared for an honest answer, and seeing that he wanted my candid opinion, I told him I was glad Hashem Bey had ridden three days instead of us. The old man rolled with quiet laughter, and taking hold of my arm a little tighter, said: "I am glad to see you are a judge of human nature as well as of horses. While he's the Sheikh of all, there are thousands of men in his own tribe that are far better than he, as men. He is angry, as you know, because the Governor of Aleppo gave you the Maneghi, but let me tell you something more: he has already expressed an unwillingness to put his seal on the horse's pedigree. But," and the old man's eyes flashed, "I will force him to do it or else make him appear ridiculous before Allah and his own tribes."

Hashem Bey seemed to be more interested in our rifles and guns than anything else. I presented him with my rifle (a special "Sav-

$[153]$ 


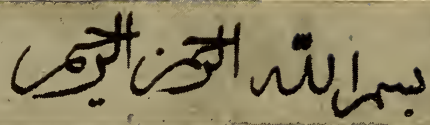

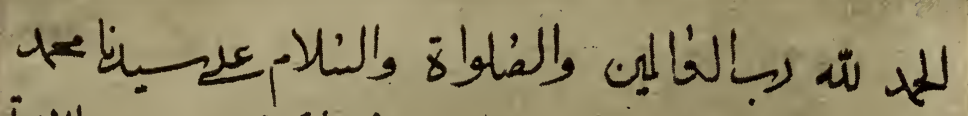

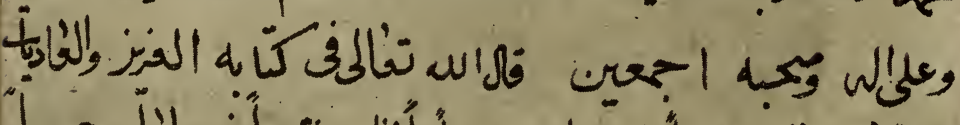

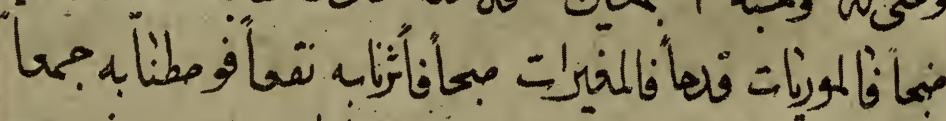

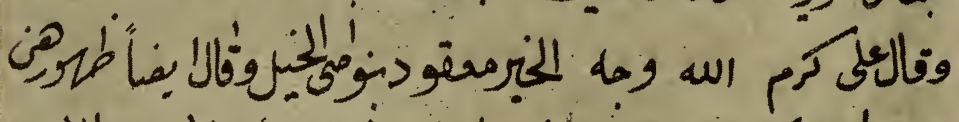

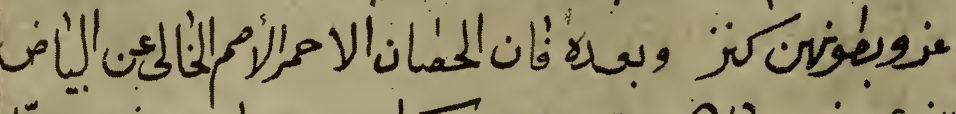

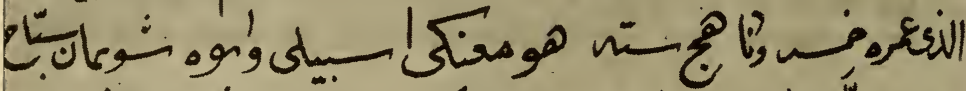

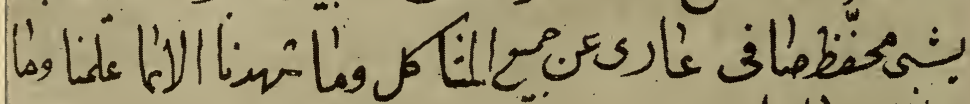

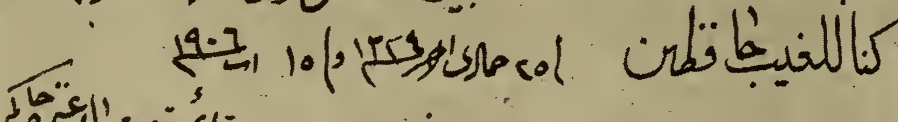
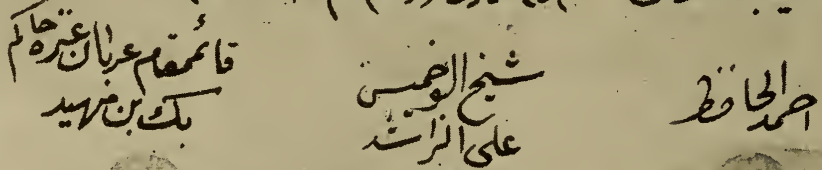

Pedigree of Haleb, the brown Maeghi Sbeyl, the favorite stallion of the desert of 1906 . This pedigree bears the seals of Sheikh Ali Rashid, Achmet Haffez and Hatchem Bey. It is a pedigree that would be bowed to from Nejd to Aleppo.

IN THE NAME OF THE MOST MERCIFUL ALLAH :

Praise be to Allah, the Lord of all the nniverse, and prayers and greetings upon our Master Mohammet and npon Praise be to Allah, the Lord of
all his family and his followers.

all his family and his followers. strike fire, and which make an incursion in the morning, raising a clond of dust and piercing the ranks of a host." Also All, may God bathe his face with glory, has said: "Plenty is knotted to the horses' nanes." He has also said : "(on) Their backs are splendor and (in) their wombs are treasure.",

And now: the pure brown stallion who is devoid of white and whose age is five years, going on his sixth, is a Mahnaky Sabily. His sire is Showainan Sabbah, who breeds pure and exclusive, and is consequently free of all defects. And we have not testified except to what we have known, and we are incognizant of the unknown.

And we have not testified except to what we have known, and we are incognizant of the
Written the 25 th of Hamada the last 1324 (Hegira) and the 15 th of Augnst, 1906 (A. D.).

(Signed) AнмаD HAFEz. (Signed) SнЕiки Fl-Bouкнамis. (Signed) Kaimakam (Governor), Anezeh Araòs, AL1 EL-RASHID,

HAGIM BEK MENHAD, 
age") and with all the cartridges I had with me, and he took them not so much as a present as an addition to his supply of guns. Of course we discussed horses with him at great length, and, as the highest authority in the world on Arab horses, he cleared away many doubtful points relative to the breed. I had my Arab horse books along with me, including the last volume of Roger D. Upton, in which he mentions all the familieseand sub-families of the Arab horse. These were carefully examined by the Sheikh, and those which were considered "Chubby" by the Anezeh were marked thus. He said the Abeyeh Sherrakieh mare, which Arthur Moore had just ridden back from Aleppo, had the rarest head there was in the desert, and she, herself, was one of the most valuable of mares.

Moore had come to the desert an entire skeptic on the subject of Arab horse. He had heard in America so much talk about the Arab by ignorant people and had failed to find any proof of their stories, that he was an entire disbeliever. He went to the desert convinced that our Cayuse horses could outrun, outlast, outwork and outdo the Arab in everything except looks. 


\section{MY QUEST OF THE ARAB HORSE}

But on the way back from Aleppo he was entirely converted and became an enthusiast. As I mentioned above, he was riding the Abeyeh mare and determined to put his to the test. It was a foolish thing to do, for the heat was terrific and the mare had a bad cough and cold. At home she would have been in the

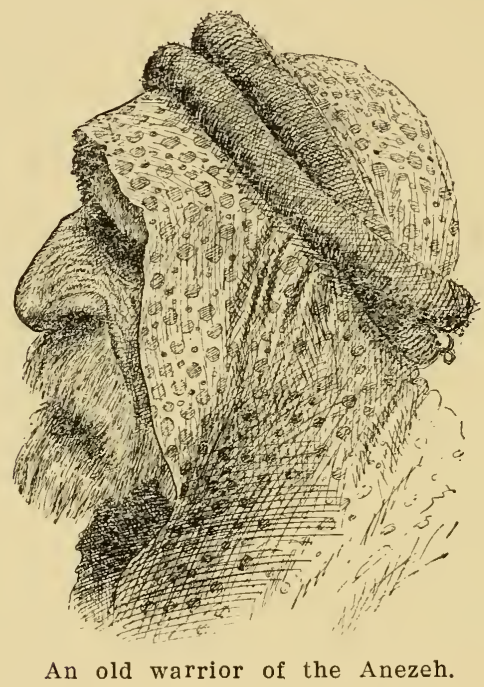

care of a veterinary. Moore, with his rifle and ammunition and $\$ 4,000$ in gold, which he was carrying, weighed 300 pounds. Nevertheless he galloped her thirty-five miles in four hours and a half, carrying all the weight. $\mathrm{He}$ did [156] 


\section{MEE'TING WITH HASHEM BEY}

not follow any beaten roadway, but took her over the rocks of the desert in a bee-line. The further she went, he said, the stronger she seemed to get, and the better she seemed to move. At the end her cough did not seem to be worse, and when Moore was on her she didn't seem to be tired. She showed some of the effects of the test when she was standing still by continually resting. Moore wanted the Arab horse to show him something, and he got it without getting it second-hand. From that time on he stood up for the Arab horse.

What made this trial of the mare the more wonderful was that while she was considered among the Anezeh as their greatest race mare, she had probably never before had on her back more than 150 to 160 pounds. While Moore was riding her the first evening we left Aleppo, Akmet Haffez had outrun everybody in the party with his Hamdenieh Simrieh filly, until he came to race the Abeyeh mare. Then, to the utter astonishment of everybody, this small mare, carrying the handicap, easily outfooted Haffez's horse in a half mile run.

Among the horses we purchased at this time was a bay Seglawieh Jedranieh mare, owned by an old Bedouin, who wore a most tattered 


\section{MY QUEST OF THE ARAB HORSE}

Keffeyeh or headdress and whose face was one of the most expressionless I had ever seen. She sat low to the ground, but was very powerful and broad; her head, though not like the

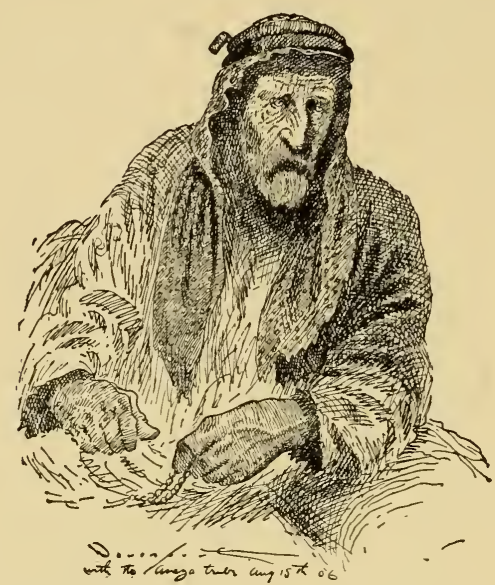

When I offered this expressionless old horseman a hundred and fifty pounds (French) for his Seglawieh-Jedranieh mare, with a grunt of disgust he mounted and rode away.

Abeyeh Sherrakieh's, was an expressive one. The fact of her being a Seglawieh Jedranieh made her of unusual interest and more than a thousand Bedouins gathered round to see her. She was a beast of evidently unusual power. Akmet Haffez asked me quietly if I wanted her, and I said I did. He advised me not to [158] 


\section{MEETING WITH HASHEM BEY}

pay over one hundred and twenty-five Turkish pounds, but at my suggestion he offered one hundred and fifty, and the mare was led away by the old expressionless man, with a sneer on his face. She was taken away and hobbled near some other horses, and her owner came in under the big tent where he joined the circle of others who were smoking, always preserving the same cold countenance.

His face was so remarkable, and his eyes so void of any emotion, that I inquired of him if he would object to my drawing his picture. The expression of his face never changed; he just gave his hand an upward toss, and a grunt, which meant "No."

We were shown other horses of the Anezeh, and bought a white mare, a Maneghieh Sbeyel, standing over fifteen hands high, which was to foal within ninety days from that time. Her eyes were large and very black with brilliant high lights, but at the same time with a soft kind look.

Arthur Moore, who had missed his present in Aleppo by leaving us at a critical moment, was presented with a five-year-old stallion, a Maneghi Hedruj. In the afternoon we had the big camel feast. 


\section{MY QUEST OF THE ARAB HORSE}

We spent several days with the Anezeh and the faces I had admired so much at first had begun to wear on me. After all, these desert Bedouins were, first and last, warriors, and the constant fighting expression in their faces was becoming monotonous. The idleness in which they lived, with no purpose in life other than to sit around till some raid was started, was wearing on me.

We had enjoyed our stay; we had feasted on a camel (they said it was a young one); we had talked horse pedigrees with the Anezeh for days without interruption; we had seen the greatest animals they had, and now owned some of them; we had bought nearly all the horses that my Irade would permit to be exported; time was flying and we were a long way from New York. It seemed when I looked at the map as if we never would be able to get there. Next day was set for our departure, and after one of the most enjoyable nights of our visit, passed in listening to horse stories and desert legends, we retired about eleven o'clock, and were up by daylight getting the luggage ready to start. The farewell feast was over, our tents were coming

[ 160 ] 


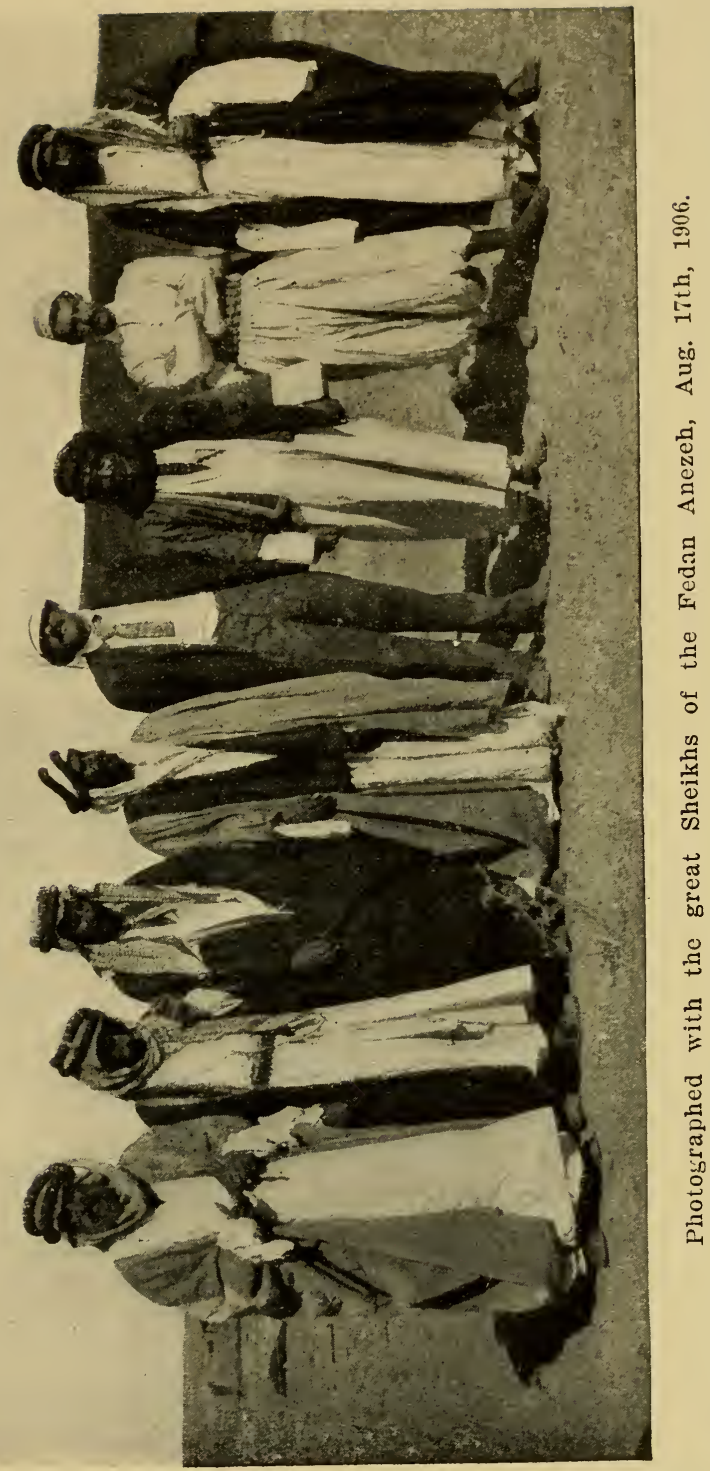




\section{MY QUEST OF THE ARAB HORSE}

down and our stallions and mares were being led off.

My dear old Bedouin brother, Haffez, knew that I liked the farmer Bedouin best, but he came to me, resting his weight on my shoulder as he leaned on me and holding Ameene by the other hand. $\mathrm{He}$ had one request. $\mathrm{He}$ asked that when I bade Hashem Bey good-bye, I should wish him success in his wars. That, of course, was perfectly reasonable, and we both hoped that it would soothe Hashem, for he was still cross about the "Pride of the Desert."

And the time had nearly arrived to start; the last coffee tune was being played and the Maneghi Sbeyel stallion was saddled, waiting. Hundreds of Anezeh horsemen were bidding him good-bye, and tying blue beads in his mane and tail, to keep off the evil eye. Akmet Haffez gave me the signal and we all arose. Hashem Bey knew, of course, that we were leaving. He walked out from under the tent where the seal-brown stallion stood fretting to join the other horses. I took the Sheikh by the hand, and told him, through the interpreter, that I hoped he would live a long and happy life, and that when he had to die he would die

[162] 


\section{MEETING WITH HASHEM BEY}

on horseback in the heat of war. He raised the back of my hand to his forehead, and we parted. He gave the Maneghi a good-bye. Sheikh Ali, of the Abu Gomuese, walked by my horse, holding hands for a few yards, to assure me that they had all enjoyed the visit, and we were off.

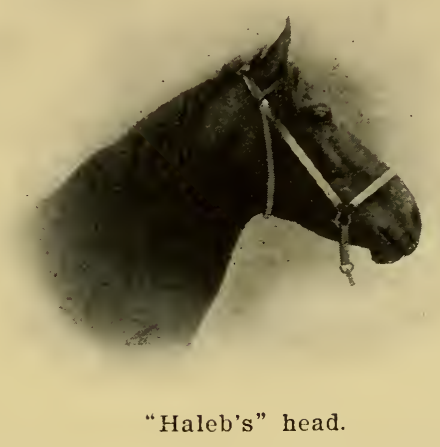

At Chicago in 1893, the World's Fair Arab horses were unable to stand up in their Bedouin shoes on the slick polished dirt, and the Arabs, shortly after their arrival, changed to the American horseshoe. I saw the small horse, the subject of the following letter, have both his forward tendons practically cut off by overreaching. Notwithstanding that, about

[163] 


\section{MY QUEST OF THE ARAB HORSE}

ten years later, with a drunken groom, he ran away about twenty miles. Before he was sold to Mr. Shoemaker (the present owner), he was "let down" in his hind pasterns.

In view of this I think Mr. Shoemaker's statement most remarkable. It shows a performance greater even than Moore's in the desert, or that of General Colby's riding in Nebraska on the Grant stallions.

Mr. Shoemaker writes as follows:

"I purchased the Arab stallion 'Koubishan,' which I have since re-christened 'Nasir Khosran,' of Mr. Davenport, on April 1st, 1906. $\mathrm{He}$ is a horse perhaps 19 years old, 14.2 hands high, of a peculiar color. I rode him daily in Central Park last spring, and early in June shipped him to my country home at McElhattan, Penn., which is situated in the wildest and most mountainous part of that state. hundred miles through the mountains, never going less than thirty miles in a day. We did not go continuously, however, as I frequently rested at attractive spots to enjoy the country, but never stayed more than a day in one place.

"During the balance of the summer I rode him from time to time, but while I was absent [164 ] 


\section{MEE'TING WITH HASHEM BEY}

in New York he was never exercised. Despite this, he was just as fresh and sturdy as if in constant use. Early in October he was exercised by my hired boy, and towards the middle of that month I started on another tour with him. We traveled along Pine Creek to Morris Run, Penn., by easy stages, and on October 14th started back. The day was fine for what proved to be a memorable ride of seventy miles. The temperature registered at thirty, the sky was clear and the ground covered with frost. 'Nasir Khosran' or 'Koubishan,' carried, including saddle and myself, two hundred and ten pounds. I was accompanied by my cousin, Mr. James W. Quiggle, second, and my friend, Mr. G. Scott Smith, who rode tough western ponies. We left Morris Run at seven o'clock in the morning and arrived at McElhattan at seven o'clock in the evening, resting two hours at mid-day in English Center. We kept up a stiff pace, averaging seven miles an hour for the entire seventy miles, which resulted in the western ponies playing out after thirty-five miles, but the Arab, carrying his heavy load, finished the trip alone in first-class condition, although the roads were all up and down hill, and the next morning he

[165] 


\section{MY QUEST OF THE ARAB HORSE}

was as fresh as ever, and did not even lose his appetite. That, I think, is a pretty good test for the Arab horse, and proves him to be adapted to the most exacting work in the roughest country, for it is almost impossible to have imagined what he would have done if he had been a much younger horse. He is to-day in superb condition, and during Christmas holidays I drove him in a sleigh, where he showed great speed." 


\section{CHAP'TER XIII}

STAR'TING ON THE RETURN JOURNEY AND SOME ORIENTAL BARGAINING-THE BEGINNING OF THE STORY OF THE MARE.

Hashem Bey was left behind, and though our faces were once more turned toward the west we were still in the desert and were to have more adventures and to witness more shrewd oriental bargaining on the part of Akmet Haffez. After leaving the main body of the Anezeh we rode for five hours and camped near a spring which bubbled up from under the hot rocks.

We were waked in the morning by the neighing of the horses we had purchased and found we had been aroused by the approach of a Bedouin riding a bay mare and leading a two-year-old colt.

The latter, it seemed, was the Seglawi Jedran colt, which the Anezeh had promised to send to me for inspection. Before we could [ 167 ] 


\section{MY QUEST OF THE ARAB HORSE}

leave the tent Haffez sent word to us to stay in our tents as long as possible. This Seglawieh Jedranieh mare, he said, was the finest possessed by the Anezeh. She had been brought, not to be sold herself, but to show what her colt was worth. He would buy the colt as cheaply as possible and then, later, would refer in an off-hand and indifferent way

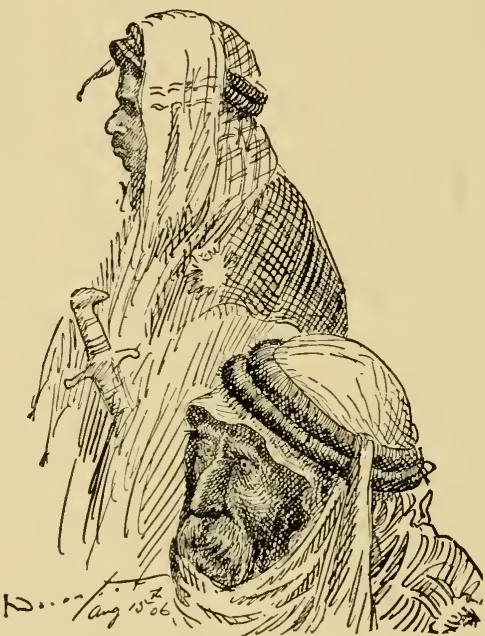

Curious visitors much astonished at watching me sketch.

to the mother. Through the flap of the tent we admired the pair. Mother and son were as much alike, in general character, as two peas. There were the same markings on their white [168] 


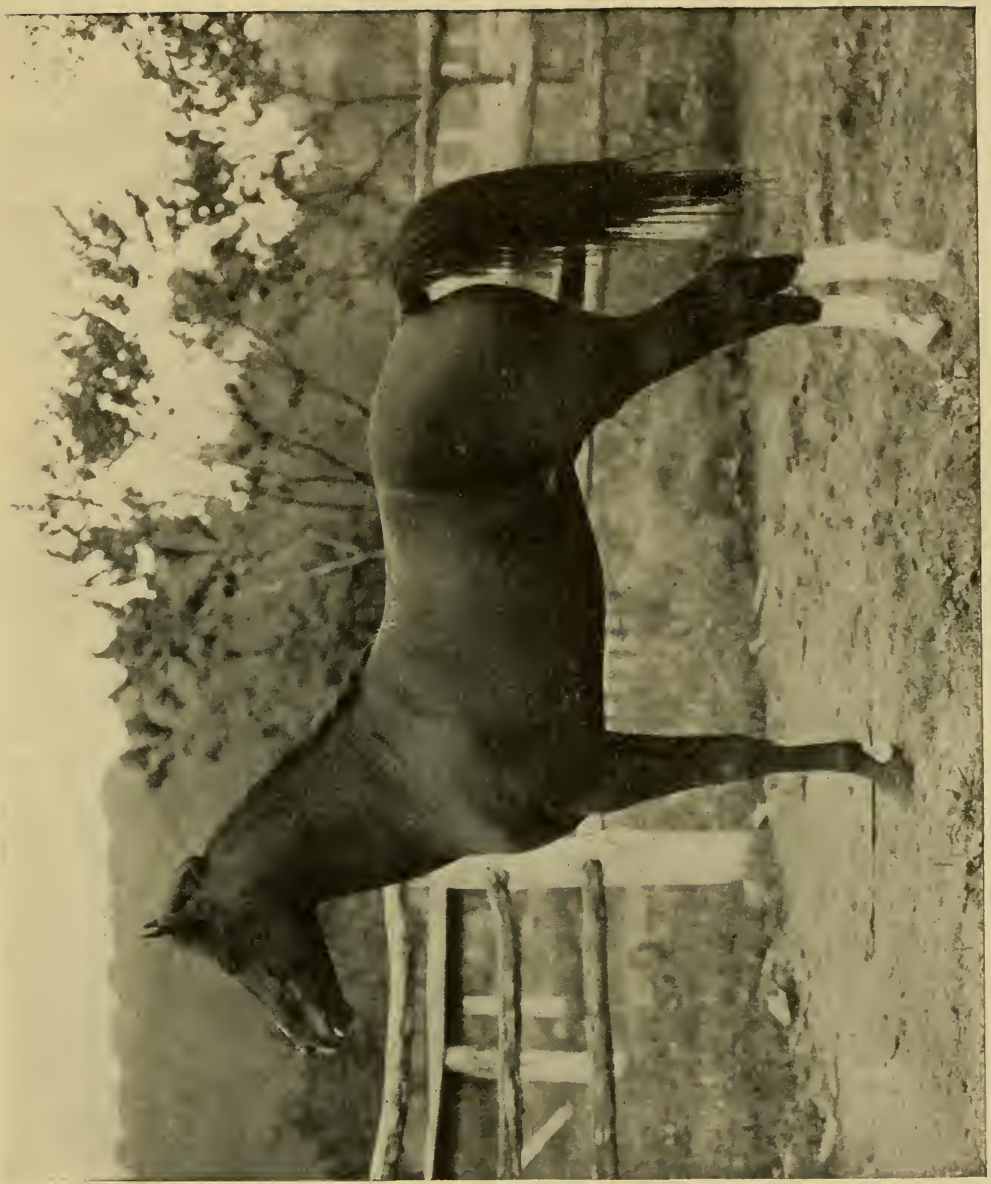

a

ฮั

敬

¿

3

또

ขึ

त)

$=$

ฮี

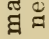

요욤

글

공

$\Xi$

记

ชด

‡

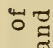

ํํㅇำ

$\rightarrow F$

'0

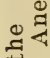

돈

菏 


\section{MY QUES'T OF 'THE ARAB HORSE}

legs, the same general character of hind quarters, and the same very "racy" appearance throughout.

We dressed and walked to where the two were standing on a plot of grass about twenty feet square. There was much delay in getting the colt. Haffez, the wisest old horsetrader of the desert, thought it was not best to buy him too quickly. He and the Bedouin had agreed closely enough to a price to make the final arrangement an easy matter; still he thought it would be policy not to hurry the deal. He wanted to wait; not that it would make any difference in the eventual price of the colt, but it would make it easier to buy another colt, a yearling and a full brother of the one in question. Moreover, in case we wanted to bargain for the mare, the effect of an hour's delay might mean something notable in the matter of price.

After all there is a fascination about this oriental bargaining. Arabs will never set a price on their horse. Unless your price suits him he will lead his horse away, nor will the desert Bedouin under any condition tell a lie about his horse's breeding.

After breakfast the Bedouin was brought [ 170 ] 


\section{STARTING ON RETURN JOURNEY}

to me, his hand was placed in mine, while the Arabs jabbered and I knew that the colt had finally been purchased. The Bedouin even promised that he would go to his tent and bring the yearling brother of the colt, a chestnut with the same markings, and join us where we were to camp that night, five hours on towards Aleppo.

As we departed the mare was a picture. She walked with the grace of a well-bred woman; her tail would gracefully sway from side to side; her ears were ever in motion, and her eyes sparkled. The very sight of her rested us from the long day's ride of the day before and then she broke into a gallop and her swinging tassels were soon lost sight of as she disappeared on the horizon.

The mother out of sight, we turned to look at her two-year-old son. He seemed finer than others we had of the same age. There was an inherited dignity which the rest did not have. We were already anxious to see his full brother which was supposed to be better still. Both of them were sired by the great HamdaniSimri chestnut horse that the Anezeh are so proud of and thus combined the two rare breeds of the desert, the Seglawi Jedran and the 


\section{MY QUEST OF THE ARAB HORSE}

Hamdani Simri. The mother was a Seglawieh, and thus according to desert rule the colts were of blood of the Seglawi Jedrans.

That night we camped at a village owned by relatives of Akmet Haffez. At ten o'clock the Bedouin returned with his beautiful mare, bringing her baby and last child, a chestnut colt, big for his age, with white in the face, and with the same peculiar white feet as his mother and brother. His mane and tail were light yellow, giving him a babyish appearance. $\mathrm{He}$ was even finer than the two-year-old.

Again I was driven away by Haffez (who wanted to drive a close bargain) lest I might show how much I wanted the mare for which he soon wanted to make an offer. I went into the tent, but was very restless. I could tell there was some friction. Finally I saw the Bedouin mount the mare and start off with the yearling by his side; and, after hearing that Haffez had let the bargain fall through because of a difference of four pounds (\$16.00), I got him to reconsider. A man with stout lungs brought the Bedouin back and again his hand was put in mine, and the yearling was bought. And now for the first time I thought we were to make an offer for the mare, but 


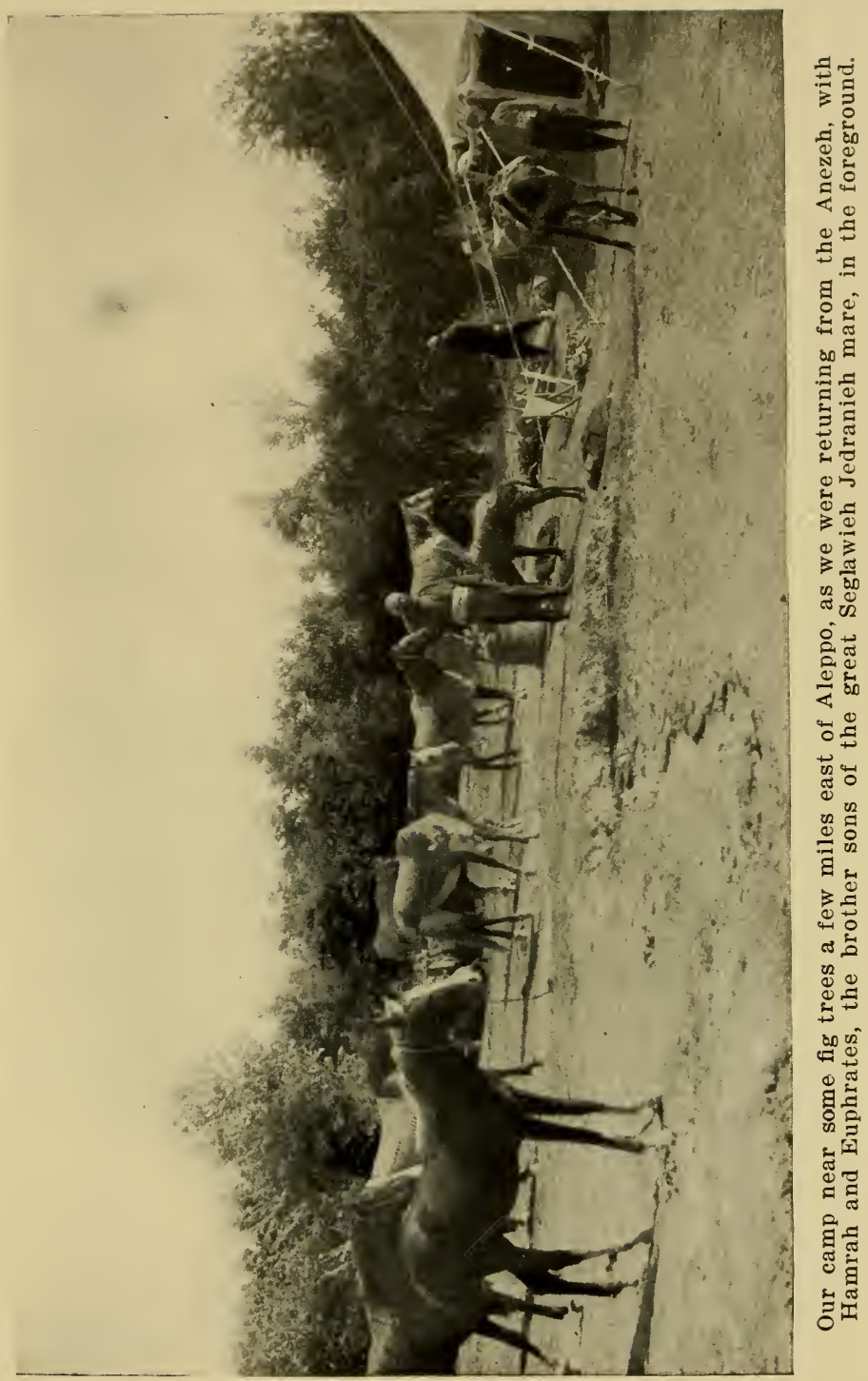




\section{MY QUEST OF THE ARAB HORSE}

Haffez, it seemed, had tried to drive a bargain for both the mare and colt, and had failed. The colt was taken to his brother and tied to the hind leg. He stood like a little man and his brother was glad to see him. The mare's only other colt had been bought the year before by the German government for two hundred and fifty pounds. Thus she was a source of revenue which they did not want to lose.

Before her owner mounted the beautiful mother to ride away, I approached her, and, true to the Bedouin custom, she refused to let me come near. She bit at me and pretended to kick, and all this while ragged Bedouins were patting her, and patting her; but me she watched like a hawk.

All our attempts to buy her proved unavailing. He put us off by saying that he would have to consult his family. He promised faithfully to come to us again the next night, but he did not and so the story of the eventual purchase of the mare is the more remarkable and must be put down in its proper place. 


\section{CHAPTER XIV}

ANOTHER PRESENT-HASSAN TASSHIN PASHA AND HIS HORSES.

THe route of the next day's journey took us more to the south, and as we passed an encampment of the Sebaa Anezeh, a brown mare, with a filly colt not more than fifteen days old at her side, was shown to us. Haffez was especially anxious that I should see this filly, as it was sired by the horse I was riding (the Maneghi Sbeyel), and was his double over again, without a white hair and with the same peculiar head. She was a dainty little thing as she played round her mother, but I was afraid she could not stand the long ride to Alexandretta. Haffez, however, thought otherwise, so I finally bought the mare and filly. They were of the family of Hadban Enzekhi, the first we had seen in the desert, and I was glad of the opportunity to buy them as it completed the purchase of representatives 


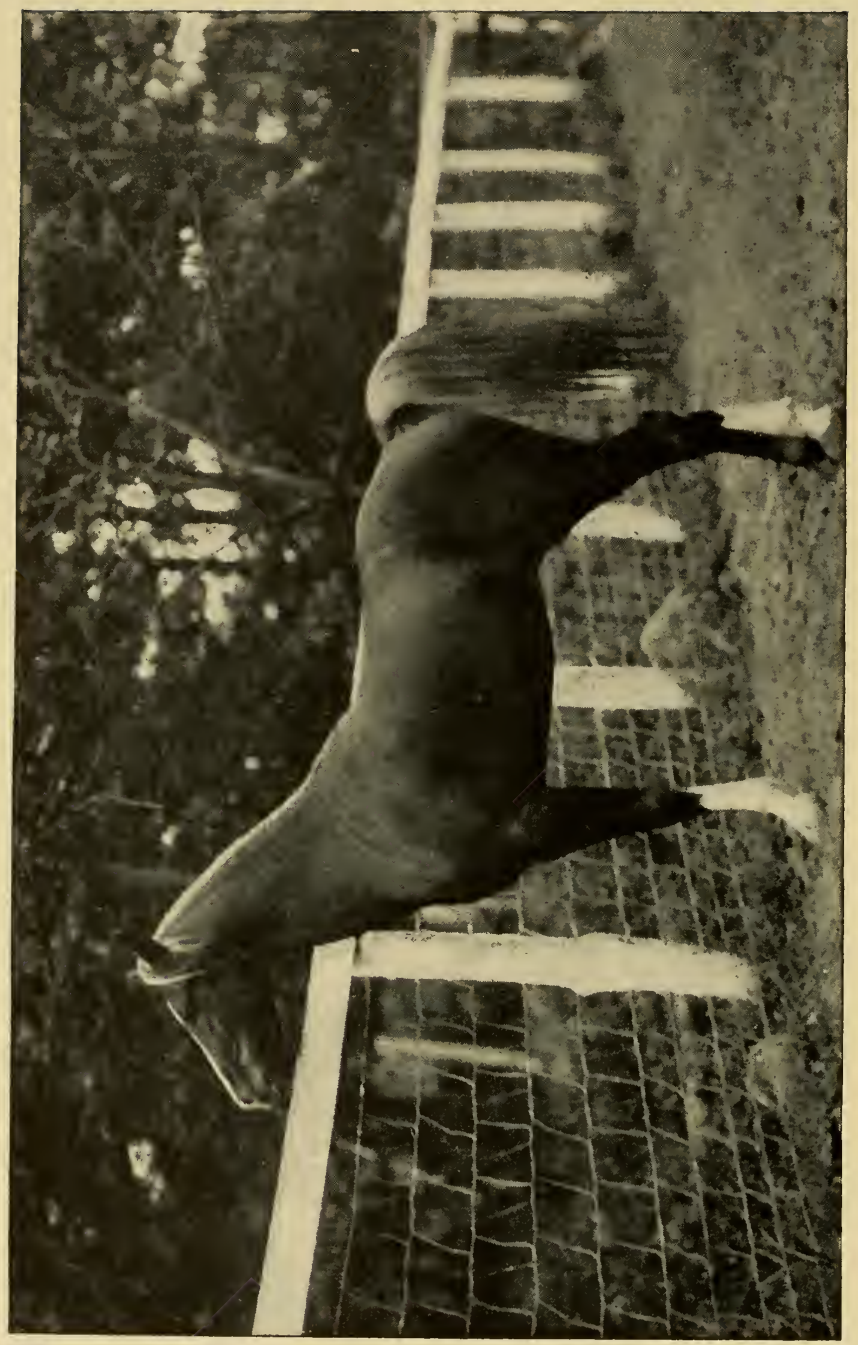

อี

$\stackrel{9}{\square}$

$\stackrel{\sigma}{\sigma}$

$\stackrel{\oplus}{\text { I }}$

$\stackrel{0}{3}$

记

跤

동

แै.

무

땅

윤

밀

कD

ขึ으

ह్ర

氶

웅

:

$\Xi$

$=$

造 


\section{ANOTHER PRESEN'T}

of all of the members of the Khamseh, or five great families. The mother was a most showy animal, with remarkable shoulders and hips, and the most graceful neck and tail carriage. As the Bedouin owner galloped her here and there over the rocks to show her off, she was a beautiful sight. It seemed the Bedouin wanted to sell the mother and not the filly colt, but Haffez knew what he was after, and bought the two at what he considered was a price for the mare alone. Her former owner followed us to Aleppo and then offered us sixty-five pounds Turkish for the colt, which was then twenty days old. But I kept it.

It will be remembered that the owner of the distinguished mare we wished so much to purchase had said he would join us that night, and all night the lonesome colt had been calling for his mother. He clung to his brother, but would call to every passing horse or camel. When we moved towards Aleppo, however, he strode alongside of his brother, and had forgotten all about his mother before we stopped for the night. All night we waited for the Bedouin and mare, but they did not come. The next day a courier came with a message that we might have her for fifty pounds more 


\section{MY QUEST OF THE ARAB HORSE}

than we had offered, and though it seemed useless, we sent a messenger, and a soldier, with the money to bring her to Aleppo.

On our return to Aleppo we were the subjects of great curiosity. All of the distinguished Arabs and Turks came to see our horses, and they were much admired.

The Governor's son, Hickmet Bey, had been presented by the Gomussa tribe with another Maneghi Sbeyel, to take the place of the one which they had given to me. We went to see him. He was two years old, unshod, and stood a fraction over fifteen hands high. He was the most powerfully made horse, I think, it has ever been my pleasure to see. His remarkable hips and shoulders were a sight. There was not a flaw in him. The Bedouins, when they came near him, all bowed. They thought he was a special creation of God, because he had three black feet, the only white being on the left fore foot, which is a special mark of Allah. He had a small star on the forehead, the strip growing wider as it came to the nose, so that it took in one nostril which was completely white. The white ran to the under-lip, and this was tattooed in blue in imitation of the women of the desert. One

$[178]$ 


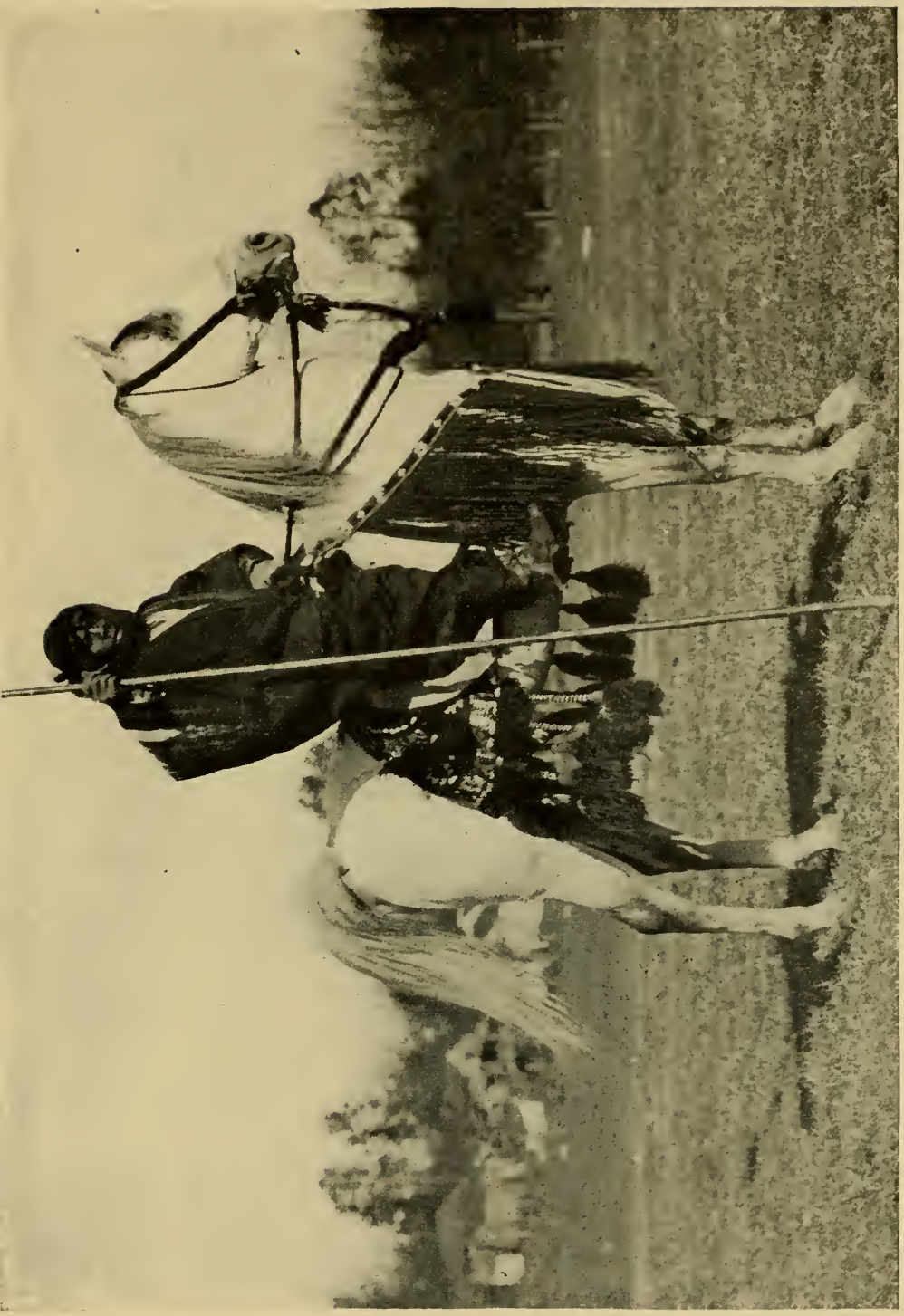

运造苛

2.

王告

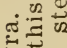

.

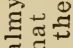

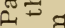

늉

记

๘

త

范 $\Xi 2$

约模

ב ๑

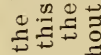
능 $\& \frac{0}{3}$ $=$ 哥 ส 평 ธี 证要 :

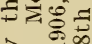
b. ธo เิ I $40 \stackrel{\circ}{\circ}$

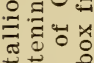
$\because \approx$ के 60

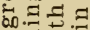
$1 \equiv \infty$. 元

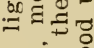
ถี 党至范 ฮี ฮี 


\section{MY QUEST OF THE ARAB HORSE}

of his eye-balls was white. In this country such a thing would be disliked in a horse, but in the desert it is commonly found.

Every time I looked at Akmet Haffez he closed his fist and held it up to his head, to show what a remarkable colt this was. To cap the climax the Governor's son told me that as he had not yet made me a present he would give me this colt. With all the thanks that I could scrape up I took him, and he was hurriedly led away to join the rest of the horses which were picketed at the Maidan, just out of Aleppo.

While at the Governor's we met Hassan Tasshin Pasha, the wealthiest citizen in Aleppo, though an exile. The Pasha was one of the most distinguished-looking men I had ever seen. He was as cheerful as an exile could be, and lived in the best house in Aleppo. Instead of pining over his fate he had taken to breeding Arab horses, and he was a stickler for fine blood and an expert with pedigrees. $\mathrm{He}$ believed that there were very few Seglawi Jedrans left in the north of the desert, and that the Hamdani Simri were confined almost to the Shammar. We eagerly accepted an opportunity to see his horses.

[180 ] 


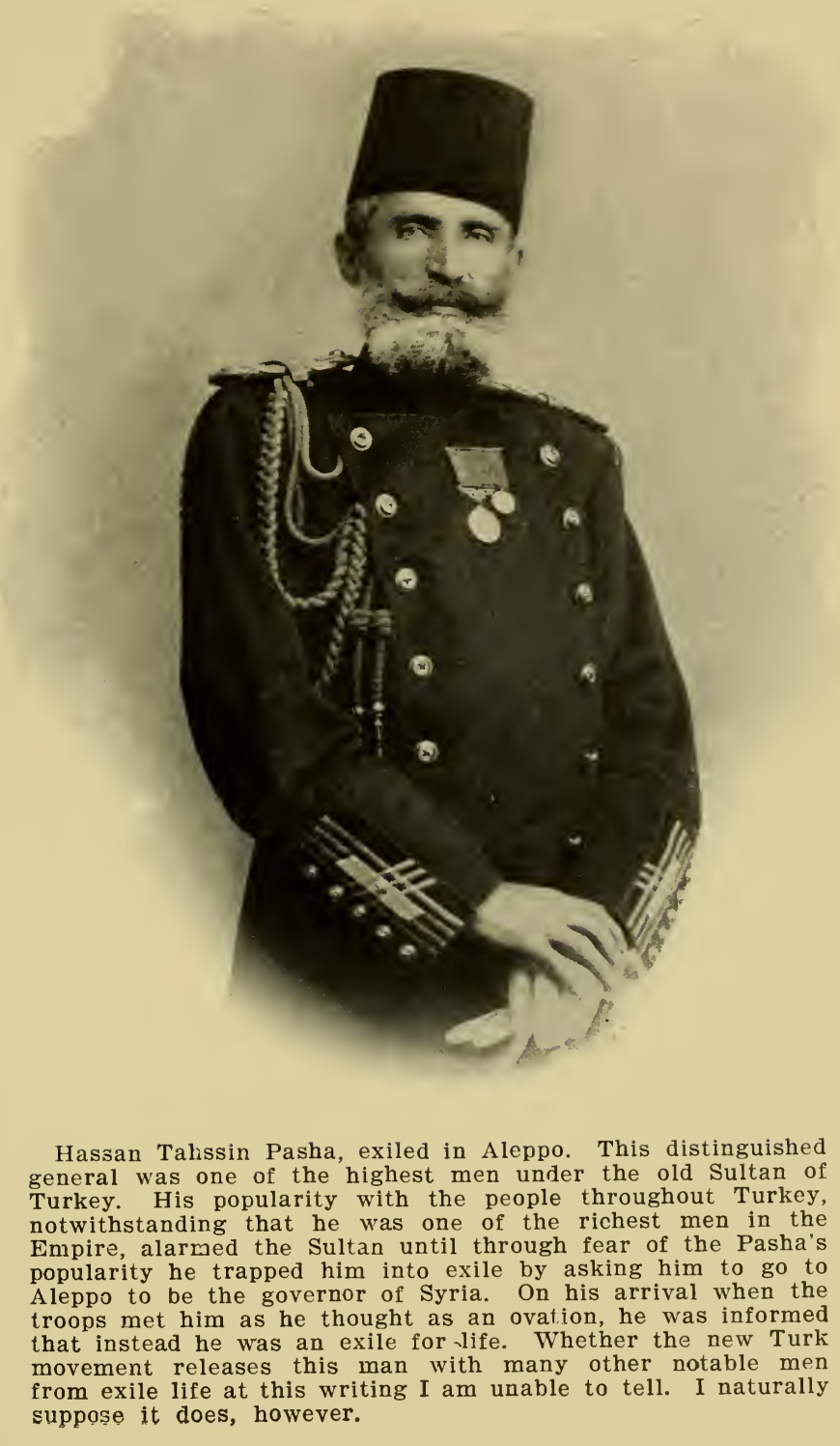




\section{MY QUEST OF THE ARAB HORSE}

The first mare that was led into view was a flea-bitten, tall and well-made gray mare, standing more than fifteen hands high. She was a Kehileh Heife, a breed much prized, as we had found out from the Anezeh, and playing at her side was a baby horse colt, foaled in June of that year. The colt was fat and husky and was chasing dogs. At a distance he looked like a Clydesdale, without the hair on his legs, and much resembled Reysdack's "Hamiltonian."

The Pasha was pleased at our admiration of his horses, especially as he had been apologizing for them. Indeed they were as fine as anything we had seen in the desert, especially a three-year-old Kehilan Heife stallion, standing fifteen hands, without a white hair on him; a dark gray Dahman Shahwan, two years old; a three-year-old chestnut stallion, a Seglawi Jedran, brought specially for the Pasha from Nejd, and a chestnut filly two-year-old Kahileh Heife, daughter of the flea-bitten gray mare.

We saw Akmet Haffez in conversation with the Pasha, and soon the latter began to talk with much emphasis. It seemed that Haffez was trying to compel the Pasha to sell us the three-year-old bay stallion and that the Pasha [182] 


\section{ANOTHER PRESEN'T}

had felt embarrassed at being considered a horse-dealer. But Haffez insisted and finally prevailed.

The next morning we went again to see the Pasha's horses, and immediately he and Haffez were at it again. Haffez's price bothered our host, and the latter made the declaration that he would not sell them at any price, but if I wanted to accept them as gifts I could. I was afraid Haffez would destroy our friendship with the Pasha, but he seemed to know what he was about and finally compelled the sale of the three horses at prices which he thought were honest. So, amid much excitement, the gray mare and her colt, and the three-year-old, were picketed with our lot.

And we parted the best of friends. The next day he called on us at the hotel with the Governor. This in itself was an unusual proceeding and the proprietor of the hotel was much excited over it. It was with much regret that we said good-bye, and as they drove away in a carriage drawn by two gray Arabian stallions, we felt very proud to think of having such friends in even such an out-of-the-way place. 


\section{CHAPTER XV}

WE SAY FAREWELI TO AKMET HAFFEZ AND START FOR THE COAST-"THE PRIDE OF THE EUPHRATES" COAIES TO US AT LAST AND MEETS HER TWO SONS.

That night brought the beginning of our farewell to the desert, for we were to part with Akmet Haffez and for the last time to break bread under his hospitable roof. Crowds had gathered around his house. Strange Bedouins whom we had never seen, were there to say good-bye in their solemn cordial way, but the old man was all smiles (for us), as he personally superintended the spreading of the bounteous feast.

And so we too feigned light-heartedness, in spite of an undertone of sadness. We would eat his food-and then leave a friend, one of the best we had ever met. Few men in any country would have gone out of their way so far as to have done for us what this diplo-

[184] 


\section{WE START FOR THE COAST}

matic, far-seeing old Bedouin had done. The Governor of Aleppo had told us that Haffez was looked upon as the smartest and shrewdest Bedouin that the Ottoman Empire had ever known. But we knew more of him. With his jocular humor and sarcasm and his true gen-

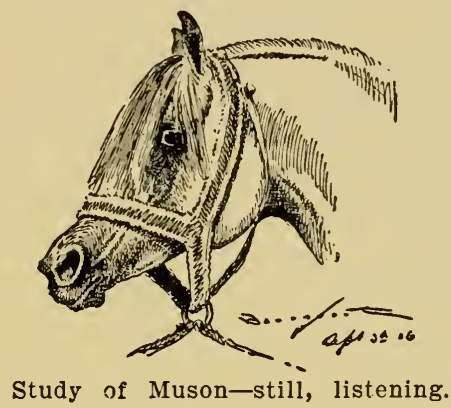

tlemanly manners, he made us feel as if we were leaving home and going abroad to some strange land.

At this final meeting he was just what he had ever been. His speech was always full of flamboyant oriental exaggeration, but it was different from that of his kind-you knew that he meant what he said. The Arabs have a word "Halamy," which being much of a slang term, can best be transferred into English (or rather American) as "hot air." The Arab showers on you all sorts of fine phrases and [185] 


\section{MY QUEST OF THE ARAB HORSE}

you accept them with a grin and say to yourself "Halamy," and letting it go at that, immediately forget it.

But with Akmet Haffez it was different. After you had once gained his friendship you knew that what he said was never "Halamy." At that last feast (shall we ever forget it?) we sat for a long time and, as we ate, joked of the trials we had had in the desert, laughed at the thought of getting a real Turkish bath when we reached the coast, and wondered whether we could stand the sensation. Then as the end drew near our mood changed, and Akmet Haffez began what in any other Bedouin would have been "Halamy."

He gave thanks to Allah that we had come to him and that he had been spared to see us. Our going, he declared, was the great sorrow of his life, but he had this one great consolation: We had learned to eat rice with our hands with the Anezeh and we ought to stay and be real Bedouins. By the brightness of our eyes (so he said with a kindly twinkling of his own) we had won the tribes, and their friendship would always be ours. So almost in silence we finished the meal, and went to the street below to say good-bye. Rare and beau[186] 


\section{WE START FOR THE COAST}

tiful presents had been bestowed on us, and distinguished people came and were presented, and when we walked down to the carriage there was a procession.

As I turned to say good-bye, I thought I saw in his motions that Akmet Haffez wanted more than a hand-shaking. So though awkwardly, I admit, I presented both cheeks and was seized in fond embrace by the old Bedouin, who broke down and began to sob almost aloud. He called to the interpreter to come closer, and taking him by one arm asked him to tell me that now indeed he had a brother in America, and that if I did not return soon he would in a few years come to make me a visit, to see if I had preserved the blood that I was taking away in his horses. Turning then to Moore and Thompson, the old gentleman with dignity, though weeping, bade them goodbye, while crowds of Bedouins stood close to the carriage. His stalwart son, Ali, also came and then we were driven away to the Maidan on the outskirts of the town, where, on a grass plot, our horses and mares were picketed ready for the march.

Yet we were loth to start, and there was another reason for this beside our unwillingness [187] 


\section{MY QUEST OF THE ARAB HORSE}

to part from Akmet Haffez. The Seglawieh Jedranieh mare, whose two sons we had bought and to complete whose purchase we had sent by a soldier the fifty pounds extra demanded by her owner, had not appeared. All through the dinner Akmet Haffez had been noticeably concerned over his non-appearance. At first he smiled and said that the heat might have delayed his coming, or that some accident might have happened. But as the time went on he became more serious. We were compelled to leave that night in order to catch the steamer at Alexandretta four days later and we had our large string of horses to convey 106 miles.

As the servants were serving coffee the soldier came in out of breath and he had not said many words before Akmet Haffez's eyes blazed with anger and he arose and picked up a rifle from the couch. What was the trouble? This simply: The mare's owner had counted out the fifty pounds brought by the soldier and then had demanded further a revolver he had seen one of our party carrying.

That was what had roused our host. $\mathrm{He}$ had given his word before Allah that we should have the mare and he would keep his word if it took rifles to help him do it. 


\section{WE START FOR THE COAST}

And the old man had his way. "I will send to get the mare," said he. "My own son Faiot, who is also your son, shall go and he shall bring her back alive or her owner dead." I yielded, not without hesitation, for I wanted the animal, as she was the best in the Euphrates valley, and, anyway, to ease my conscience I sent along the revolver which her owner had demanded. Faiot and the soldier started at once on their fifteen hours' ride as we broke camp in the opposite direction. They would try to catch us on the second night.

It was nearly two o'clock before we were ready to march. The young stallions had rested from their trip from the desert. The barley and the regular feed which they were getting was beginning to tell on their condition and it was with difficulty that the man led some of the two-year-olds, so frisky were they and so full of play.

We rode all night and until the sun was hot and at eight o'clock in the morning stopped at Kafar-al-Teen, the spot named after the famous bandit of that name. All-night travel is not best for man or beast. The horses were tired and sleepy and, worse still, Moore was sick and not improving. The heat of the day

[ 189 ] 


\section{MY QUEST OF THE ARAB HORSE}

affected us more than if we had not been traveling the previous night, so I planned a new programme. We would start that evening at six and ride three hours, then rest during the comparatively cool night so that the little colts might sleep.

The men of the caravan objected to this and threatened to leave us, but I insisted, and so, backed up by Thompson and Moore (even though the latter was sick, he looked to them big enough to lick a dozen Arabs), they stayed. That plan saved us. We camped at nine-thirty and at ten the young horses were all asleep, and when we started at three in the morning, some of the two-year-olds were hard. to hold. We rode from three to seven, and then stopped until evening.

At sundown Moore was getting steadily worse. I was watching the pious Bedouins performing their evening devotions with their faces towards the east when I turned to look at the sunset. It occurred to me, seeing Moore's condition, that the west was the place for us to pray towards and said so to Moore. He was so sick he could hardly hold up his head, but he managed to lift himself a little and said that if we could manage to hurry him [190] 


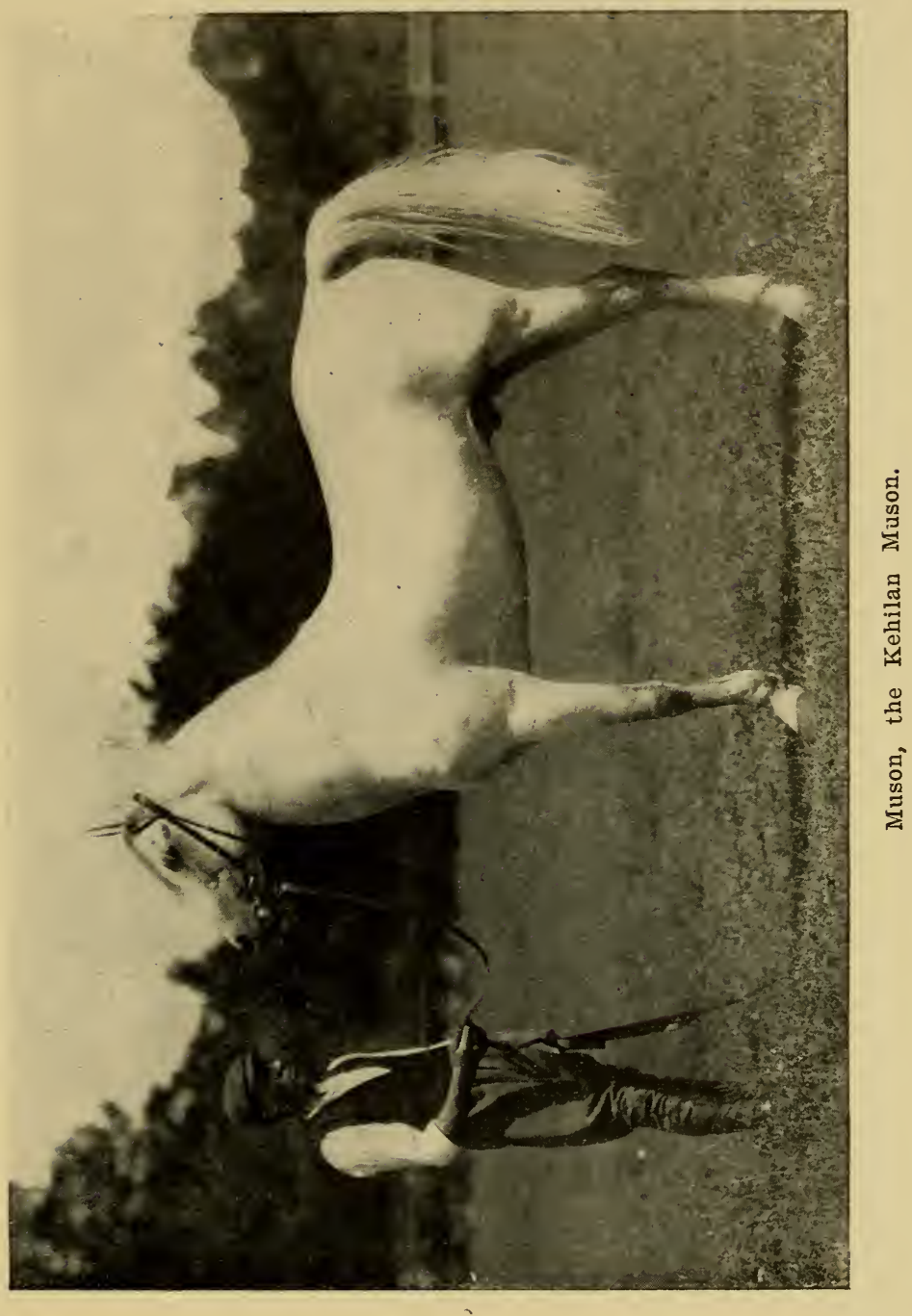




\section{MY QUES'T OF THE ARAB HORSE}

toward the west, a little nearer Broadway, he would feel better. And we tried. We got him on his horse somehow and started on again.

One of the horses, a golden bay from the private stables of Hassan Pasha, was sick, too, but that was nothing. A local veterinary indeed offered to cure both Moore and the horse with one prescription, which he declared was infallible. He said that if the sick man should lead the sick horse past the graveyard both would immediately recover. $\mathrm{He}$ guaranteed the cure before Allah. We declined with thanks. Besides, there wasn't any graveyard.

It was now the third night out from Aleppo and there was no news from the mare. Suddenly about nine in the evening there was a cry of "Faiot," and the son of Akmet Haffez came galloping up on "The Pride of the Euphrates." She was the same beautiful animal despite her journey. Her eyes had the same sparkle and she looked better than when we first saw her. Some of the grooms were watering the horses at a nearby stream, and her colts were away from the camp ground at the creek. But while she was still resenting our approach, the chestnut orphan colt came in on the run. He was all excite- 


\section{WE STAR'T FOR 'THE COAST}

ment; his eyes glistened and his ears nearly touched each other at the points as he ran from one horse to the other. His excitement was so great that we shall never forget it. It seemed as if such an unexpected meeting had never taken place before. Those who may think that dumb animals have no way of expressing their feelings, should have been present at this twilight celebration. The colt fairly kissed his mother and his joy knew no bounds. He tried to be her baby again and suck, forgetting that he had long been weaned. He kicked up his heels and cantered about, stopping to lick her all over. Then, with a squeal, he started, with his little tail high up, to run and run round her. He almost stampeded some camels with his antics. He ran so close to the other horses we were afraid he would trip on their hobbles. He forgot he was tired and leg-weary, forgot his baby feet had no shoes. Fifty Arabs and grooms, and we three, were half laughing and crying together to see the boy celebrate his joy. All this time his mother acted bashfully as if she were saying: "Don't mind him; he's just my boy." The grooms tried, when he was tired out, to fasten him near his brother, but no hob- 


\section{MY QUEST OF THE ARAB HORSE}

bles would have held him. He wanted to sleep by his mother. He was not content until he could.

The interpreter then had a story to tell. While the colt was celebrating the reunion, his once owner was not so happy in Aleppo. When the son of Haffez went to him with the revolver the owner found fault with the weapon, saying it was not the one he wanted. $\mathrm{He}$ was so sore that before he would give up the mare he declared he would leave the Anezeh tribe and go to Brihem Pasha, who, to get the blood of his mare in his tribe, would defend him with his six thousand armed men. Whereupon the soldiers covered him with the very pistol he had sent for, while Haffez's son, Faiot, took the mare by force. Later he was arrested and brought to Aleppo because he had broken his word about a horse which he really did not want to sell. But if we had achieved one horse we wanted we had lost another. The golden bay had died while the celebration of the colt was going on, and before the last tent wagon left the spot the jackals were barking on the mountains nearby.

The next day at Alexandretta, the Arabs from the mountains knew all about the bay

[194] 


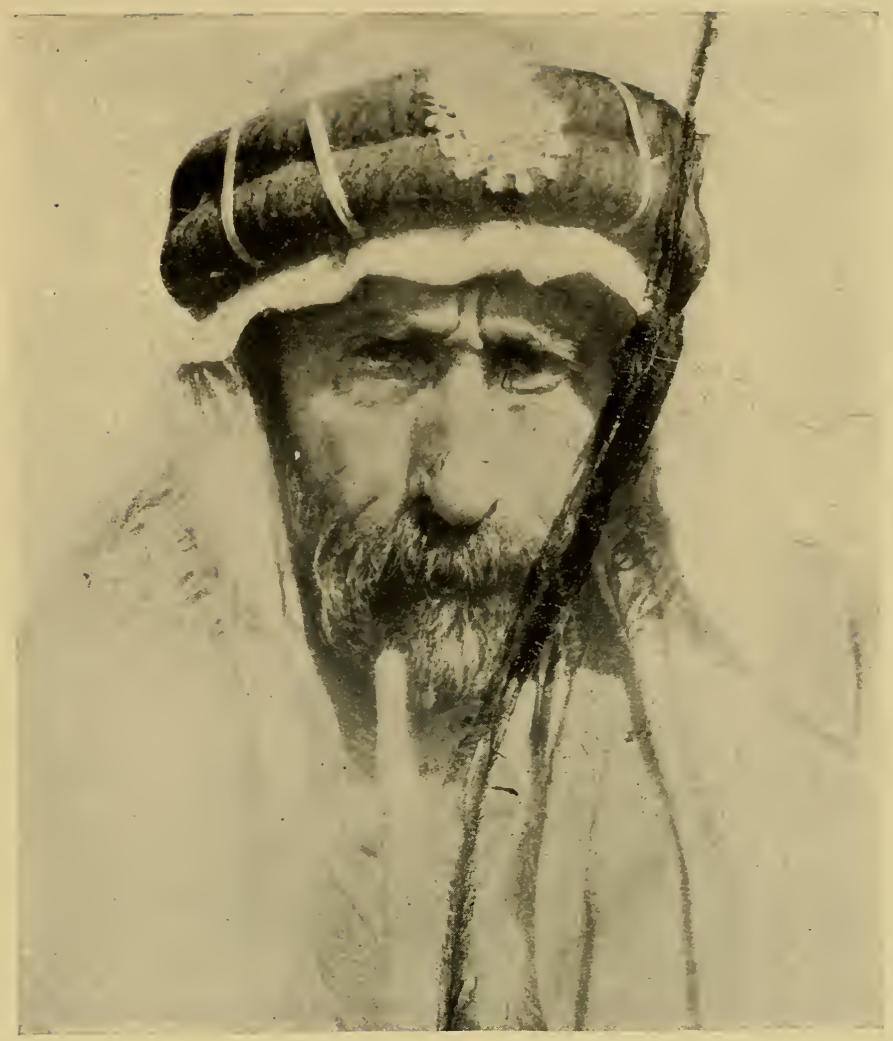

\section{BRIHEM PASHA}

This rather remarkable photograph, remarkable owing to the history surrounding it, was taken in Urfah by an English traveler. The Pasha at that time was the Governor of that Province, but on being recalled by the Sultan, he and his soldiers turned outlaws and fled to the Desert with their arms and ammunition with the hope at the death of the Sultan to be able to defeat the Anezeh. On hearing that this photograph had been taken of him-the only one ever taken of him-the Pasha sent an officer to kill the possesscr of the picture and destroy it. The man was killed and the photograph torn in two and thrown in the street, the officer fleeing to the Desert to avoid alrest. The reproduction here shows where it was torn and mended. Brihem Pasha did not live to fulfill his prophecies, as he was assassinated a little over a year ago by agents of the Anezeh. 


\section{MY QUEST OF THE ARAB HORSE}

mare, though we had not told the story to a soul. They came to see her in great numbers, and were sorry she had been taken away from her owner.

That night two New Yorkers sat beside her and played pinochle till daylight, and when she was safe on board the steamer, I felt the relief that only her presence on the steamship could bring. 


\section{CHAPTER XVI}

WHAT ONE MAY OVERLOOK IN THE SHIPMENT OF HORSES-WE LEAVE THE OTTOMAN EMPIRE AND ENTER ESSENTIAL PART OF IT AT LEAST, ALTHOUGH SURROUNDED BY SPIES.

How that pinochle game came out I do not remember. Maybe I won, but whether I did or not, my mind was more set on evincing the game of horse-that is of getting my purchases safely out of the country.

When you're at home sitting on the shady side of your porch and planning the exportation of Arab horses, there are some details which you overlook while seated in a comfortable rocking chair. Generally, when you are reading of the exportations which have been made into England, you read something like this:

"We brought from Damascus, or Aleppo, a bay mare." Then follows a description of how this particular mare enjoyed the grass in the 


\section{MY QUEST OF THE ARAB HORSE}

paddocks in England. So I had been careless and even ignorant of some of the things I afterward learned must have happened between the time that horse was purchased in the desert and when you again hear of it in the English paddocks.

Before getting to Alexandretta, I had ordered, by wire, from Mr. Jackson, the American Consul there, lumber to build stalls on the boat; and had given little thought as to how the horses were to be loaded on the ship. Until I reached that part I had no idea how difficult that would be. If Mr. Jackson had not gone ahead with the work, and had not had boxes constructed for me, I could not have shipped my lot of horses for at least two weeks. He had made contracts at the lowest bids and every carpenter in the town, who was well enough to work, was working day and night on the boxes. Mr. Jackson was constantly after the carpenters and the work was done on time.

If you have never put twenty-seven stallions and mares into the first boxes, or stalls, they have ever seen, then there's something in life which you have yet to experience. The day on which the embarkation began was very hot.

[198 ] 


\section{THE SHIPMEN'T OF HORSES}

The poisonous mosquitoes were dipping under your hat-brim like bees. On the dock you were conscious that there was a spy, who was there smiling at you and to you and anxious to hold his umbrella over your head. You allowed him to do this, but at the same time you knew that he was watching to see if he could not find some way to stop you legally. You also knew that in the little town, possibly between the wharf and the place where your horses were tied by the legs, were men who would like to steal some of the choicest ones, especially the Seglawieh Jedranieh mare, or the Maneghi Sbeyel stallion. If those men once got on the back of any of these horses nothing could catch them. It would be a short run of an hour into the mountains and then-the desert, where everything is lost. A fortune you knew was waiting for the man who could get away with the brown stallion.

These trifling details had never been in my mind when I was at home rocking in the shade, desert-dreaming, but they were forced on me now with other little things. Nevertheless the shady porch in Morris Plains at the other end of the journey was on my mind as well as the thought that I was determined to win out.

[ 199 ] 


\section{MY QUEST OF THE ARAB HORSE}

At the last minute, though the good health of the horses had been testified to by a veterinary, other veterinaries stood waiting to be tipped and bribed, lest they should get into trouble with the Turkish spy, who was anxious to have his name go before the Sultan. All this time the heat was getting more intense.

It was ten o'clock and we'd been up since before daylight trying to hurry things along. Barley was being shipped aboard, seven thousand pounds of it, as well as hay, or stuff which they call hay. The first horses were being brought to the boat, and to try and get some relief from an upset mind, I asked them as a favor to bring the Maneghi Sbeyel stallion along first. He had never seen a box-stall and had never been asked to walk into one before, but I thought that with his broad forehead he would know more than some of the other colts. The Maneghi approached the box. With five hundred curious town Arabs looking on, he stopped for a moment to gaze at it, and then at the first asking he walked in with a majestic swing that characterized all his motions. The door was closed behind him and fastened by an iron bar.

It was I, I think, who suggested that a [200] 


\section{THE SHIPMENT OF HORSES}

bandage be tied over his eyes before they lowered him into the lighter, but when we covered his big black eyes he began to get nervous, and at the first move of the box he nearly got out of it. When he made one real effort, the box that had looked so stout, bound as it was with iron, seemed as frail as a chicken coop, and we wondered if it would ever hold together till we got to the steamer. Faiot, Akmet Haffez's son, had come with us and he knew the stallion better than we did. He saw what the trouble was and tore the bandage from the horse's eyes. Then the Maneghi peered out of the box and into the water and immediately grew quieter.

The horse never moved after his bandages were taken off. He was calmer by 50 per cent. than I was during the whole operation. The next they brought was the chestnut two-yearold Deyr colt. He had been so playful when we bought him that there were a double set of hobbles on his legs and even with them he cavorted round. But like the Maneghi Sbeyel he walked into the box, and without a bandage over his eyes he was perfectly quiet, looking over the landscape as they swung him up into the air, and down into the small boat, without [201] 


\section{MY QUEST OF THE ARAB HORSE}

even a move. In the meantime another difficulty had arisen. While these stallions were gentle and kind, still they would fight if they could put their noses together, so I asked some of the Arab grooms we had brought with us to hold each one by the head. Then, an underling of the spy, whom we suspected, objected. He told our interpreter that no man would be allowed to go with us to the boat for fear they might leave the country. We tried to explain. We told him that if the stallions were left free to nip at each other's noses, the soft wooden boxes would be smashed to splinters. But there is no reasoning with spies. We had to appeal to Mr. Jackson and he finally gave his word that each man who went to the boat would be returned, and finally it was settled that way.

Among these grooms was Said Abdullah, whose name translated means "The Happy Servant of God." This cheerful person (for he was nearly always on a broad grin) had been the slave of Akmet Haffez, and when the latter had given the Seglawieh mare to me, he announced casually that Said went with her. Of course, that was something of a poser. I tried to explain to $\mathrm{Haffez}$ that in America

[202] 


\section{THE SHIPMEN'T OF HORSES}

slaves did not exist, but I am afraid my explanation was not very clear. At any rate he insisted that as the boy had been brought up with the mare, or at any rate with her sons and daughters, he should go with her wherever she went. The mare was going with me, said Akmet Haffez; so was Said. The logic seemed perfectly clear to his mind. He dismissed the subject at once and considered the incident closed. As his guest I could do no more than follow suit and Said as a faithful servant (both of us had forgotten the word slave) has followed the fortune of Wadduda ever since.

We worked hard all day getting the horses aboard and it was nearly dusk when the last lighter came alongside with Consul Jackson. We compelled all the grooms, four of whom I had intended to take to America, to return to the shore, to be checked off. I went ashore with them to sign a few papers of release, and incidentally pay a few more bills. Following us at every step we took were the agents of the spy, and when we were having our last meal in MacAndrews \& Forbes's house, they paraded round the doorstep.

It appears that, by some accident on the part [203 ] 


\section{MY QUEST OF THE ARAB HORSE}

of the customs official who was checking off the horses as they were taken aboard the lighter at the dock, Said, my boy, had been checked off as coming back, and it had not been noticed that he had gone out to the lighter with another bunch of horses. He had crawled in under the bales of hay, and to anyone on shore he might have been taken for a monkey scaling up a rope which hung down the side of the big boat as he scrambled aboard. He was there, but I was not supposed to know it. All I was certain of was that he was on the boat.

After supper, with the sea beginning to get rough and choppy, we started for the ship an hour before she was to sail and to our astonishment found on board the three Arabs whom we had left on shore. How they got there I do not know and never asked. Said was still missing, but we had an idea he would turn up somewhere and after the steamer was under full headway we started to hunt for him. We searched and called for a long time without answer, but finally, behind the "war mare's" box, crouched down under some sacks, we found him. He was all eyes and the whites of them seemed bigger than all his coalblack face. It was a long time before we could [204] 


\section{THE SHIPMENT OF HORSES}

make him understand that it was safe for him to come out, but once out he soon saw that he was past danger of being caught and ten minutes afterwards he was as busy as ever feeding and watering the horses.

Anchoring next day at Latakia, Thompson went ashore to get some tobacco. I had made up my mind to take advantage of the stop and finish up some pictures that I had under way. Moore was not feeling entirely fit, though much better, so stayed aboard, too. Then Thompson returned and said he had found the Governor's staff getting boats ready to come out and call on us, as the Governor had been notified by the Governor of Aleppo that we were on the steamer with the finest horses that had ever come out of the desert.

I was for sticking by my pictures, but Thompson and Moore insisted, on the other hand, that we should call on the Governor, especially as he had been told of our arrival by the Governor of Aleppo.

So, not expecting anything out of the ordinary, but still against my wishes, we went ashore. There was some whispering between Jack and Arthur on the way in to the land, and some laughing. My trousers were consider[205] 


\section{MY QUEST OF THE ARAB HORSE}

ably torn about the knee and other places from riding; I had no tie, and there were a few other details of dress missing that ordinarily are of little importance in Oregon, anyway, but it seemed to be fun for the boys. Later I saw why.

When we approached the dock we saw that the town was in holiday attire. The Governor of Aleppo had dwelt at much length on the importance of our visit and the streets were jammed. As we walked off the dock into the carriage waiting to take us to the Governor's Palace, the crowd kept looking for another boat bearing the GREAT PEOPLE. They must have thought we were the advance guard.

Reaching the palace Thompson and Moore could hardly keep down their mirth. I saw then for the first time that the holes on the shins of my trousers looked a little bigger than they had before, and I felt the lack of that tie. We had to pass the Governor's guard, consisting possibly of a thousand soldiers, who were drawn up in double lines. As we passed, most of them knelt. Thompson had been through the same performance in the morning, but when the Governor had asked him for the letters from President Roosevelt, and the doc[206] 


\section{THE SHIPMEN'T OF HORSES}

uments from the Sultan, which the Governor of Aleppo had mentioned in his telegram, Jack had told him that they were on the ship with another man, so it was for these documents the town was in gala attire, and not for the men who carried them.

We marched past the soldiers to the entrance of the palace and the Governor stood in the middle of the doorway with outstretched hands to meet us. I may have been dressed queerly-I will even admit it; but when I saw the Governor I felt better. He was very short and very wide-what you would call a ponderous small man, with a white beard, bald head, and straight white hair down the back. He was a man of much importance in the Sultan's list of great men, having once been Governor of Bagdad. We went in and the servants dove here and there with the standard old regulation refreshments of coffee, cigarettes, more coffee and so on, and then in some very beautiful cut-glass tumblers, purple lemonade. We had been used to red thick lemonade, but this was purple. The Governor could not speak English, but his secretary knew a few words. After half an hour's visit, we were driven round in a grand review of the town [ 207 ] 


\section{MY QUEST OF THE ARAB HORSE}

with soldiers escorting our carriages. Then we were taken back to our boat, joined by all of the Governor's staff who wanted to see and inspect the horses and mares.

From Latakia to Naples, the trip, so far as the horses were concerned, was an unevent. ful one. We had ample opportunity to recover from the strain of the last days spent between the desert and Alexandretta and especially from the wear and tear of the shipping of the horses at the latter port. Early on that day I had nearly succumbed to the heat and was obliged to go on to the steamer. Moore had very nearly recovered from his sharp attack of fever, but was still weak, and a great deal of the actual work fell upon Thompson.

Active and strong as he was, he must, however, have received in his system some germs of the pernicious fever which one always finds in Alexandretta. He was in perfect health at the time and kept in perfect health until late in the fall of last year (1908), when he was attacked with a sudden fever, the symptoms of which indicated that he must have first been inoculated with it in Alexandretta. I regret deeply to add that the attack was fatal and that our companion of the desert passed away [208] 


\section{THE SHIPMEN'T OF HORSES}

almost before we knew he was ill. Thompson added greatly to the pleasure and success of our trip. He had the knack of seeing the cheerful side of life and thoroughly adapted himself to any conditions. He never had a word of complaint and his good humor helped us through many unpleasant times. 


\section{CHAPTER XVII}

NAPLES AND SOME OF THE MISFORTUNES WHICH OVERTOOK US THERE-AMERICA AT LAST.

When we reached Naples we felt relieved. We thought our troubles were over. According to our contract with the steamship agent in Alexandretta the horses were to be transferred from the steamer to a barge and then to the Nord America, a much larger boat, where they would be put on the middle deck in the hold. But we were wrong. Our troubles were only beginning. We learned almost at once that the Nord America was filled up with emigrants and that the horses would have to be put ashore, and possibly taken to a stable.

Argument was of no avail. We had to take the horses ashore, and the only consolation for the "shindy" that followed was that Naples had for once a real horse show. The young stallions had been eating their heads off for two weeks on a smooth Mediterranean voyage

[210] 


\section{NAPLES}

and, as I expected, once their feet touched the ground they were almost unmanageable. They simply could not walk. They bucked, and played, and reared, and squealed. The place where we disembarked them was as thickly jammed with people as is Broadway at Fulton Street at the noon hour. Beside the crowd there was a switch engine running up and down past the docks. That added to their fears.

The horses had been lowered in their boxes from the steamer to a barge, but when the Customs Dock was reached it was necessary to take the animals out of their boxes and lead them on the dock. Then the boxes were brought on to the dock and the horses had to be led into them again. That sounds easy. It was simple enough to do it in Alexandretta when the horses were tired out with their long trip. Now they had had two weeks' rest and plenty of food.

The boxes were made of soft wood and it seemed as if the excited animals would kick them to pieces. The men on the barges were bringing the horses ashore too fast and we had more than our hands full. The brown stallion, the Maneghi Sbeyel, our pride, had torn out

[21i ] 


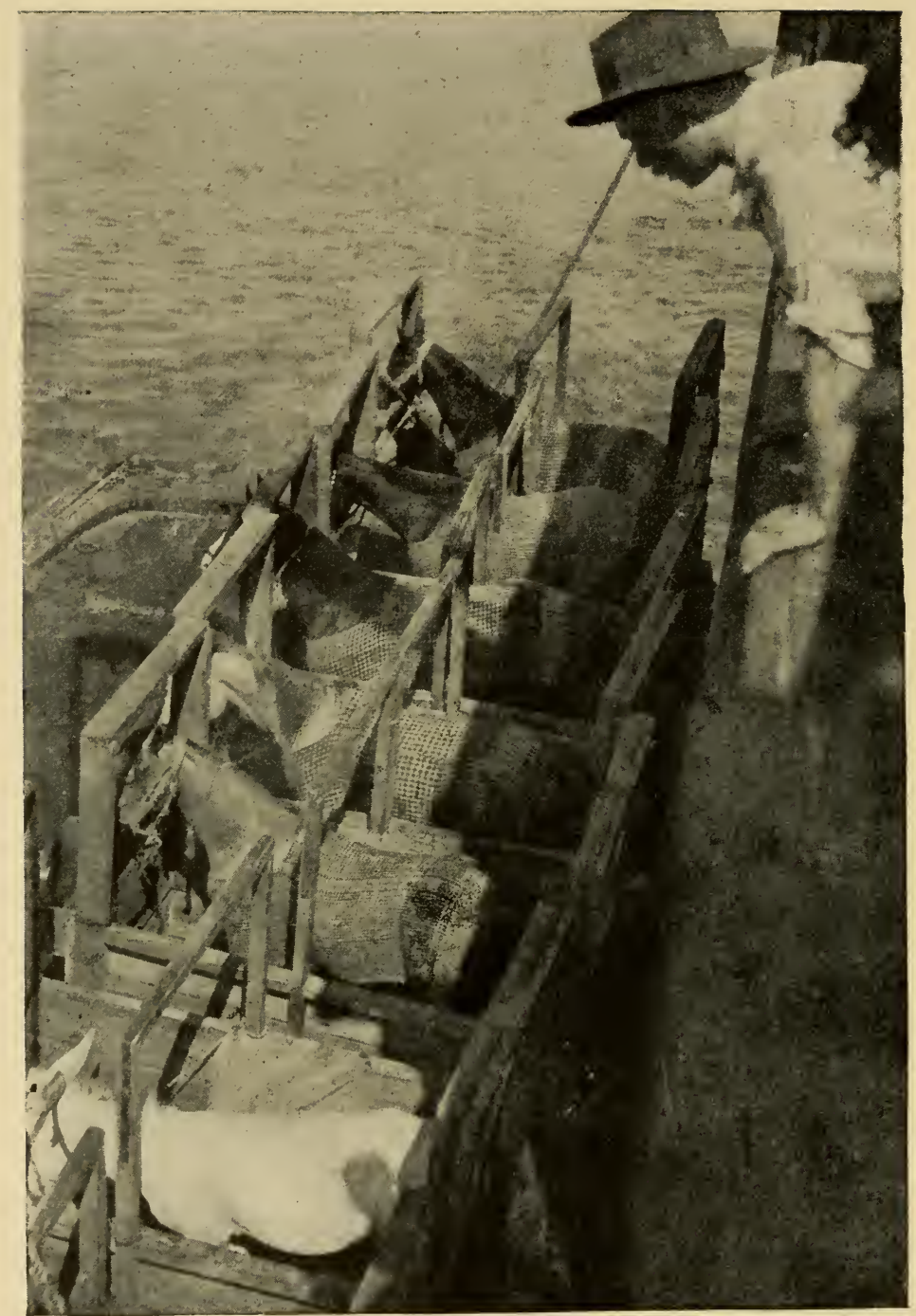

No horses were more sensible than these while being transferred from steamer to barge. 


\section{NAPLES}

the front of his box at one sweep of his forefoot, and long wire nails threatened to pierce his flesh at any moment. 'The Italians, who were handling the horses for the shipping company, had no more horse sense than Chinamen who had never seen a horse. My one stand-by, Said, who knew more about Arab horses than all the people in Naples, I could not find for a long time. When I did he was just where I wanted him to be. He came off the barge leading our favorite Gomussa, the blue-lipped colt, our finest animal. The colt, all excitement from the squealing of the stallions, was, for the time being, transformed into a wild horse. He reared, and jumped, and kicked, and snorted, and stamped. The black groom hung to him and tried to pacify him by yelling an Arab word, "Nam," "Nam," "Nam," but Gomussa had forgotten his Arabic. $\mathrm{He}$ didn't hear. He struck the groom with his forefoot and knocked him senseless, apparently, against an iron fence. I caught the colt by the halter, and he threw me off, but Said, who was not hurt, again grabbed him, and was hanging on by the head.

Neither of us had been injured, but a moment later he struck Said again, and this time 


\section{MY QUEST OF THE ARAB HORSE}

the groom was laid out. As I threw all my weight to try and keep him from climbing into the box of the Maneghi Sbeyel, some Italians placed a box in front of him, and he ran into it. Quick as a flash Said was closing the doors. Then we tied his head, but that did not stop him. He kicked and the boards and splinters flew, and to make matters worse he started the others to kicking. But Said was a wonder. He got hobbles from the barges and at the risk of his life secured the horses, and eventually we got the animals all ashore. It took all of Said's skill to quiet them and there was much kindling wood left on the docks. The horses had kicked their boxes to pieces.

And it was very discouraging. Said and Thompson were the only ones that kept up. The former insisted that Allah was with us and had imbued Thompson with the same faith. I could see no hope. The next day all the satisfaction we could get from the steamship company was permission to take the horses out of their boxes to a stable across the city. The route to it led through the narrowest of streets and it was my personal desire to put the animals back on a barge, but [214] 


\section{NAPLES}

that was impossible. I feared the worst from the attempt to lead them through the streets. However, there was nothing else to do and so our Naples horse-show began.

The procession was to start with the bay Seglawi Jedran two-year-old colt, the oldest son of the war mare, for he was sensible and quiet. Then was to come the brown stallion, the "Pride of the Desert," and after him another two-year-old. 'The other stallions and two-year-olds were to follow and the mares and colts were to come last. I was to bring up the rear with the man who was leading Wadduda, the war mare. I made Said lead the blue-lipped colt, with the best groom in Naples at the other rein, and I also had two men leading the Maneghi Sbeyel.

To my surprise, when the order was given for them to back out of the stalls, the procession moved off quietly and the horses took no notice of the trolleys, or the automobiles, which were all around them. Wadduda was gay and prancing, but her main fret and worry was to keep up with the horses on ahead. As we passed close by the equestrian statue of Victor Emmanuel, the grandfather of the present king, showing him mounted on an Arab stal- 


\section{MY QUEST OF THE ARAB HORSE}

lion, I looked up with a sigh, wishing that I could change places with him. I thought I was more fit to handle the statue. We reached the stables, though, and got in without accident.

We got back to the hotel and the temperature began to drop rapidly. The clouds were getting black, especially round Vesuvius. The wind howled and within an hour the hail was battering the blinds off. Jack Thompson came in, and slapping me on the back said:

"If you'd had your way, and put 'em back on the barges, how many horses would you have alive when morning comes?" I replied:

"Jack, none."

He said: "You're right for once. I tell you that Allah is with you, and you don't know it. Said knows it and if you will just make up your mind to that I believe that our horses will all reach New York safely. This trip has been managed by someone else, and that's been proven a dozen times."

It was nice to believe, if you could believe it. It was an easy way out of the trouble. But it did not seem true, until next morning we saw the wreck of the barge on which I had wanted to leave the horses. It was in splint- 


\section{NAPLES}

ers. Other ships had broken their anchor chains. Then it seemed that Allah had indeed saved us. The faith of Said was often comforting. And we needed the comfort, for we seemed to be completely sidetracked. We appealed to the American Consul at Naples and that official did everything both officially and personally. He communicated with all the officers of the steamship company, but all of them said in effect: "You will have to wait." Wait! We who were just back from the East knew what waiting meant! Just simplynever.

I had in my pocket the bills of lading which called for the delivery of the horses in New York on September 28, but that seemed to make no difference with the steamship company. The local agent explained easily that we would have to wait for the next boat, the Italia. The Italia arrived at Genoa en route for Naples and we were informed that she could not take horses because of the emigrants. Each day brought a new plan. Now we would ship the horses to London, but no boats would take us to London; now we would ship to France, but no boats would take us to Frances now we would charter a special steam-

[217] 


\section{MY QUES'T OF THE ARAB HORSE}

er, but there was no special steamer to charter. Should we be obliged to rent winter quarters and just wait as the agent of the steamship company had said we should do? That was not to be thought of. I decided that something had to be done at once.

I sent a telegram to the King of Italy, appealing to him as a horseman. I told him that though my horses had been billed through to New York by an Italian line, they were being held up indefinitely. The Italia in the meantime had arrived, and the captain repeated that he had orders to take on no horses, and that he would not think of doing so, as he had more emigrants than his ship could comfortably hold. Then I played trumps and cabled to the President. An answer arrived from Washington that carried with it a punch. It was plain and simple, but it demanded an immediate reply. It read:

"State Department at Washington wants to know if it is true that this shipment of horses is held on account of emigrants being shipped to America."

There was a good deal of action just then round the office of the steamship company. Ambassador White, at Rome, demanded an 


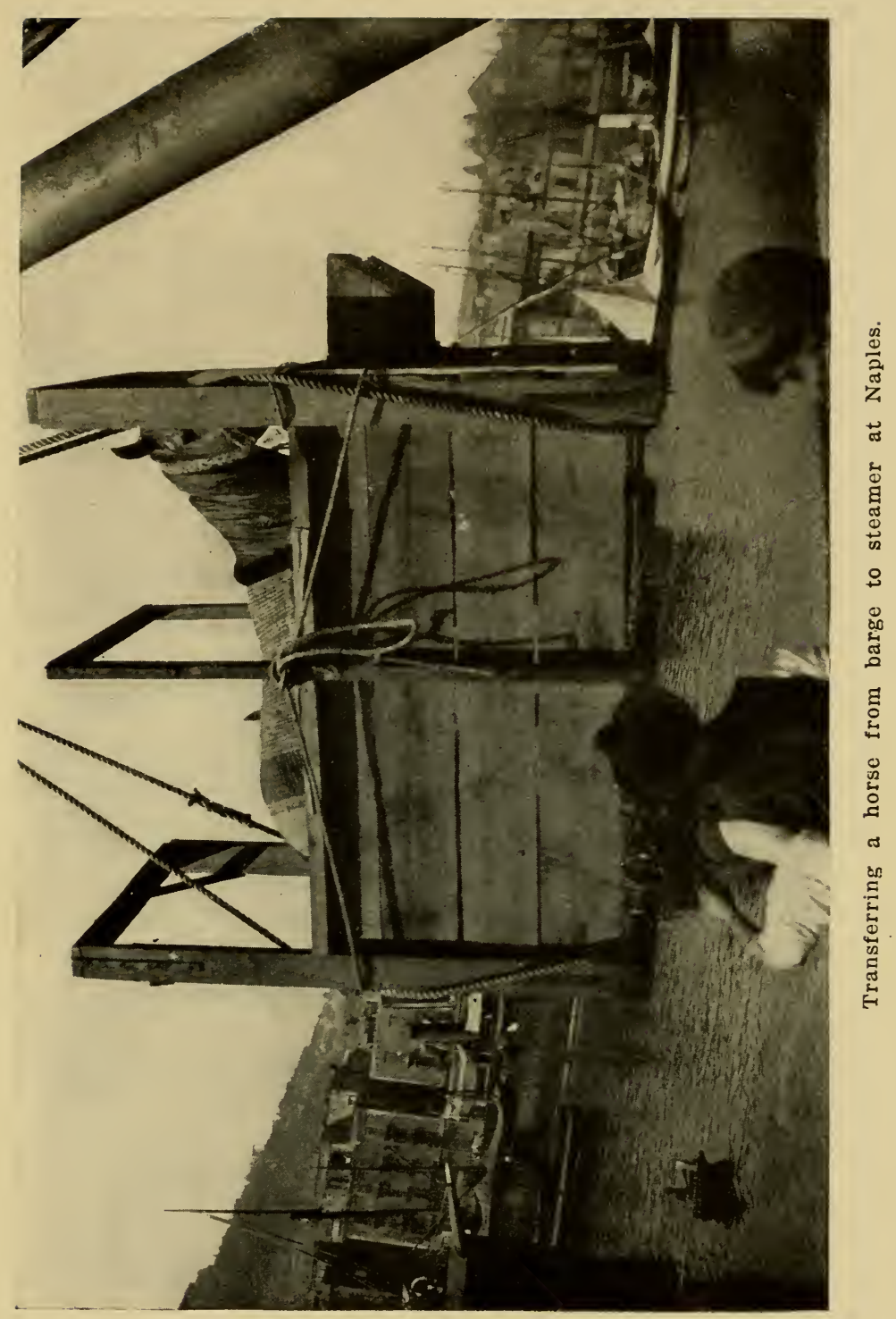




\section{MY QUEST OF THE ARAB HORSE}

answer to a telegram which he had sent and as a result the Italia was detained a day in order that the horses might be taken on board. True, there was no other accommodation for them except on the upper deck, in the very bow of the boat, where they would be exposed to all kinds of weather that might come along, but I consented to ship them. I did this under protest, as our contract demanded that from Naples to New York the horses were to be carried between decks.

Marching back to the steamship dock the horses paraded like a cavalry troop. They had created a good deal of interest in Naples and thousands of people had gathered daily to see them exercised in a small park which had a bridle path, and when we started for the steamer the streets were lined.

At one crossing the crowd was very dense, just leaving a leeway for the horses to pass. The blue-lipped colt was giving us the most trouble of any. He had on a blind bridle and it bothered him because he could not see behind him or to the sides. There was a hump on his back that showed what he might do if the proper occasion came. Right at the thickest point of the crowd, a young boy stood with 


\section{NAPLES}

a large board on his head on which were many pies. Before I could yell to him, as the bluelipped colt came by he slapped the beast on the rump, and almost instantaneously the colt kicked the pie counter off his head. It was done so quickly that the boy didn't realize what had happened. As he looked behind him to see who had knocked the pies off, they went rolling in every direction, while the hundreds of people roared with laughter. The pier was reached without further mishap and the horses were hoisted on the deck of the Italia way up among the anchor chains.

At the last minute Jack Thompson agreed to go on the ship with the horses, permitting Arthur and myself to take advantage of a faster boat which would get to New York a week before the Italia. There was nothing that could be done during the voyage, for any of the horses, that Jack Thompson could not do, so we left him, with the belief that Allah was with him, and would see him safely through. Allah was good and the horses arrived safely. More than safely indeed. Many of them had caught bad colds and coughs in Naples, but when they reached the dock in Hoboken they were in perfect condi-

[221] 


\section{MY QUEST OF THE ARAB HORSE}

tion and health. The next day storms swept the ocean, and steamers due the following day were three days late.

Many of the horses had stood on their feet from the 28th day of August until the 8th day of October, yet when they were led off the boat onto the docks, they played and pranced, with legs free from any swelling whatever. On reaching the farm, one stallion stood up in his box for another twenty-four hours before he lay down.

I had had many visions while seeing these horses eat the poor chaff and barley of the desert, of what a pleasure it would be to see them eating timothy hay and oats. So I suffered a severe disappointment to observe that none of the horses would touch these things, but ate their bedding instead. This went on for several days until we grew alarmed. Many of the mares became gaunt for want of nourishing food. They would root in their bedding to hunt for food like that to which they had been accustomed. So we fooled them in this way: we sprinkled the bottom of their box stalls with cut-up hay dampened, with oats and middlings and then bedded over it. When they rooted in the bedding they found this 


\section{NAPLES}

food, and within two weeks began to eat it out of the manger. And so the desert horses came to America.

We could not but feel some elation over the fact that the importation had been successfully carried out. It is a far cry from the home of the Anezeh to Morris Plains, and, as we had found, the journey was beset with difficulties. To have overcome them all and to have brought the string of horses in safety to this country was a satisfaction, to put it as mildly as possible. I will not speak at length here of the successful results of the importation, but perhaps those who have followed the story of the Maneghi Sbeyel stallion, "The Pride of the Desert," the gift to me from Nazim Pasha, will like to read of his achievements here. $\mathrm{He}$ has proved that horsemen are the same the world over, whether they wear the rough cloaks of the Bedouins spun under camel-hair tents or frock coats built on Fifth Avenue. The Bedouins followed us from the desert to the coast, breeding two mares a day to him.

When we reached America, our horsemen also picked him from the rest as the best animal of the lot. He was written of by experts and horsemen as being of the Morgan type, as

[223] 


\section{MY QUEST OF THE ARAB HORSE}

we had noted when we first saw him in the Governor's palace in Aleppo. In the following June, after his arrival in America, he was shown at Rutland, Vermont, at the horse show, in an open competition with stallions, for the "Justus Morgan Cup." In this contest he met representatives of the finest strains of the Morgan horse of the present time and he won. That alone was sufficient compensation for the trouble and expense of the entire journey. 


\section{CHAPTER XVIII}

OF SAID ABDALLAH AND HIS NOTIONS OF AMERICA.

Sain Abdallah, my Bedouin groom boy, constantly asserted all through the voyage from Alexandretta that Allah was with us and would bring us in safety to the end. His faith had helped us out of the dumps in Naples and his devotion to us and to the horses should not go unremembered. When Akmet Haffez presented to me Wadduda, the war mare, Said came with the gift and ever after counted himself as one of my family. To guard him against fits of homesickness or melancholy, before he had learned to speak any English, I often took him with me, especially when I took my own children to shows and circuses. He had never seen even a street fakir in his own country, so that the strain was naturally very heavy on a brain so undeveloped and at first it seemed a little dangerous to show him the [225] 


\section{MY QUEST OF THE ARAB HORSE}

wonders of the New York Hippodrome, but I did. No eyes ever saw as his did that afternoon. He had never seen elephants, nor any pictures of them. He had not even heard of the beast. His first query was to ask if they were real, or just made of cloth. He saw Mermaids come from the water and return again. If the roof had dropped in and sprung back to its place, Said would have thought it was on the regular programme.

After each show his brain was worn out for a day, and occasionally severe headaches followed, but his comments were often delightfully true.

Especially are his criticisms on the high-acting horses of the National Horse Show worthy of publishing here. He had never seen a horse artificially exhibited. He came from a race of people who, strangely enough, believe that if God did not intend a horse to hold its head up, it is a shame to pull it up with a chain. He also had the curious idea that if a horse does not elevate its tail naturally, it is cruel to dock the tail. Of course such ideas are desert barbarisms, but at the Horse Show they sounded naive and amusing.

One day, accompanied by an interpreter, he [226] 


\section{OF SAID ABDALLAH}

went to the Horse Show, and saw there for the first time, a good team of high-acting horses, a pair that almost bumped their chins with their knees. At first his eyes nearly bulged from their sockets. He held up his hands in horror as he exclaimed "Mashalla! Mashalla! Is there truly a race of horses that go up and down in the same place?"

When told that what he saw was the result of training and artificial breeding, and that the horse himself was not to blame, he uttered an exclamation of pity. Then he said suddenly: "No," and pointed above him; "the desert isn't up there, but always in front of you; God made a horse to get over it with the least effort, not the most." I have no comment to make on these remarks of Said. I do not think any are necessary.

Within a year Said had mastered enough of English to get along in ordinary conversation, especially if it pertained to horses. There was only one thing he could not understand and does not to this day. He cannot comprehend how the newspapers know that it is or is not going to rain to-morrow. $\mathrm{He}$ admits that God knows, but he is doubtful if any newspaper does. 


\section{MY QUEST OF THE ARAB HORSE}

$\mathrm{He}$ is as fine an example of faithfulness as could be found. After he had been in this country nearly a year, and had beaten off many attacks of blues, Dr. Frank Hoskins of the American Mission at Beyrout, Syria, came to the farm to see the horses, and talked with the boy who had been with the Anezeh. Reaching home in the evening, I was informed that ever since Dr. Hoskins had taken his departure Said had been crying. Evidently a fit of homesickness had seized him. I went to the barn to see him and he came smilingly from one of the dark corners. But I could see that his eyes were much swollen and still wet with tears. I asked him if he had enjoyed his talk with the visitor and he said he had, for he had spoken Arabic as if he were at home. He tried to appear happy and with forced enthusiasm told how Dr. Hoskins had admired and liked Wadduda, the war mare, and "The Pride of the Desert," best of all the horses. But he was plainly homesick for the sights and smells of the desert and there seemed to be no way to console him. His broken English only made his protestations that he was happy the more pitiful. 


\section{OF SAID ABDALLAH}

"Said," I said at last, "you have been crying."

"What cry, Mr. Davenport?"

"Your eyes," I answered, "are almost swollen shut with weeping."

His head dropped and his chest began to rise and fall. After a moment or two he said:

"Mr. Davenport, before Allah, my heart no mad."

Then he broke out and exclaimed that at night when he shut his eyes his thoughts took him to the Anezeh, and he joined the tribes as they swing to the south. Now they are past Deyr and approaching Nejd they get into war with the Shammar! Then he wakes up and finds that he is not in the desert, but in Morris Plains. He turns on the other side and sleeps; and by and by his brain goes to Aleppo and when he meets his once great master, Akmet Haffez, he grasps him by the hand. Again he wakes up, and he is still in Morris Plains.

"But, Mr. Davenport," he added bravely, "Allah knows my heart no mad."

"Well," I said, "Said, I am going to send you back to the desert."

"Said go desert?"

[229] 


\section{MY QUEST OF THE ARAB HORSE}

"Yes," I replied, "you are going back to the desert."

He broke down with hysterical laughter, and grasping me by the hands commenced to kiss them, and tell me that I was too good to stay in this country, that I ought to live with my brother in the desert.

"Mr. Davenport, Said go desert two or three months?"

"No, Said, in two or three weeks. I will find a ship, if I can, that will take you direct to Iscanderoon, Alexandretta. There you can follow the old Roman road across the mountains to Aleppo, and from there the camel caravan route to the desert."

I turned and walked away, bidding him good-night, and had nearly reached the house, when he called to me and asked if I would say before God that my heart was not mad. I will admit that after dinner I went to bed early, and did not get much sleep.

I got up before daylight, still restless, and went out, and there in the north pasture saw an impressive spectacle-the trying out of Said's religious faith. Wadduda, the war: mare, dressed and draped in all her beautiful, wild regalia, was in the pasture. From her 


\section{OF SAID ABDALLAH}

neck hung the beads of a wild tribe, and from the desert saddle long flowing tassels swayed in the morning breeze. It must have taken Said half an hour to have draped her. Sticking in the dirt at her side, towering over her head ten feet or more, was the war spear from the Anezeh. Kneeling on his prayer rug in front of her forefeet was Said, facing, as I first thought, the strip of timber across the road. But as I watched the picture I saw that he was praying toward the light spot on the horizon-toward Mecca. I watched for fully five minutes. The boy touched his lips and forehead with an upward stroke of the hand, and dropping both hands beside him, looked intently for a moment at the approaching dawn.

Rising up slowly, he picked up his little prayer rug, lifted his spear from the damp earth, while the beautiful prancing mare came to his side. Her tail was swinging proudly from side to side.

As they approached me I saw that Said's eyes were, if anything, more swollen than they had been the evening before. To cheer him up, I spoke to him first.

"Said, I thought when I saw you in the pas[231 ] 


\section{MY QUEST OF THE ARAB HORSE}

ture that you were some member of the Anezeh that had come to see me."

"La" (no), "Mr. Davenport Said no see Anezeh."

"You are going back to the desert."

"No go desert. All night Said no sleepsit down, no lay down. Go Wadduda stall, pray; come back, no answer-no sleep-pray, no sleep."

Turning, he pointed out into the pasture to the little knoll, and said that there a few moments ago Allah had answered his prayer. When he found where Mecca was, he had prayed to Allah and Allah had told him that he was not to go back to the desert; that he had been given with Wadduda by Akmet Haffez to me; and that he was going to stay as long as Wadduda lived-would stay even when she was gone, with her colt and her colt's colt, and was never going back to the desert. He has never been homesick since. 


\section{CHAPTER XIX}

THE BEDOUIN OF THE DESERT-HIS SON AND HIS DAUGHTER, HIS CATTLE AND THE STRANGER THAT IS WITHIN HIS GATES

The desert Bedouin is to the Ottoman Empire what our Indians were to North America. $\mathrm{He}$ is of two kinds-the agriculturist and the warrior who carries the lance. The two classes are in great contrast, but when you have seen both you incline towards the former notwithstanding all the poetry and glamor which attach to the fighter. Despite their racial likeness you can see the difference between them at once. The agriculturist is, of course, the more domestic. He stays pretty much in one place and is content with a mud house and a few camels, and maybe a mare or two. He is apt to have many sheep, and longeared black goats, and possibly ten or twenty head of strange-looking cattle, together with a few chickens and turkeys. He is a much kind-

[233] 


\section{MY QUEST OF THE ARAB HORSE}

er-looking man than his fighting brother. $\mathrm{He}$ lives close to the ground and likes the smell of it.

The warrior is an idler. When he walks he swings his long robes with an indolent grace that impresses you with the idea that he is not hurried for time. He has no occupation other than war, therefore his plans are not made far ahead. He keeps one mare, at least,

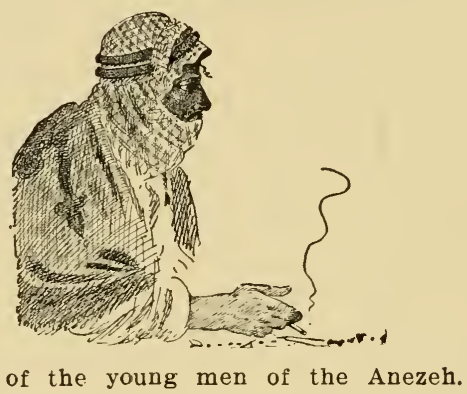

always saddled so that he may spring on her back at the slightest alarm. Near where she is picketed his long spear is stuck in the ground ready to be seized for immediate action. But otherwise he is lazy.

He sips coffee all day long, and smokes almost incessantly. $\mathrm{He}$ is fond of talking of horses and firearms, and prides himself on being a gentleman. But he will not work. His [234] 


\section{THE BEDOUIN OF THE DESERT}

eyes often gleam with a wild expression; every motion and gesture he makes is artistic and he is well imbued with the innate sense of politeness which does not need to be taught. Though you might be the first white person he ever saw, his manners are always those of a gentleman. He visits all day long, and until

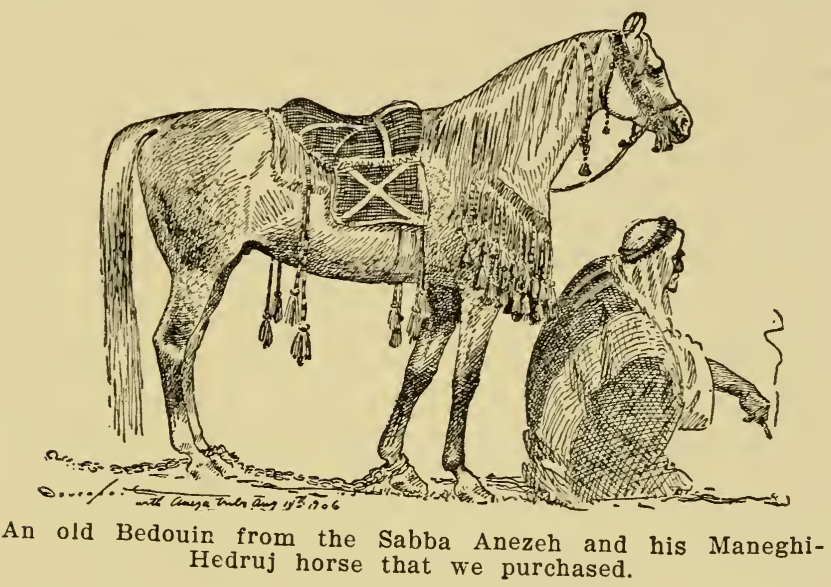

quite late in the evening; he is liable to get up at any time in the night and have coffee, and smoke, and talk, and he is generally in a good humor. But he will not work. He has a general air of weariness.

As a matter of fact, with the idea of fighting constantly in his mind, he really believes

[235] 


\section{MY QUES'T OF THE ARAB HORSE}

that he does not have time to work. As long as he has enough for himself and his horses he is perfectly willing to lead the hand-to-mouth existence which his ancestors have led for hundreds of years before him. To-day he does not know where he will be to-morrow. Although he has, in a way, a fixed route of travel he can never be sure that it will be carried out entirely according to the rule. He does not sow any crops, for he does not know who will reap them-almost certainly not himself. Why then should he work? He can always depend upon his brother, the farmer.

But underneath his indolence of manner, his slowness of movement and his chariness of speech-behind all his apparent inertia and lack of initiative-every now and then you get a glimpse of a crude, elemental force, the existence of which you had not even guessed.

At first it startles you. You have been received with the grace and charm of true hospitality. You have been made entirely at home in your strange surroundings. You have given up wondering how such polished gentlemen (and I use the term in its best sense) could be found in such a desolate, barren, God-forsaken country. Then-just a [236] 


\section{THE BEDOUIN OF THE DESERT}

look, perhaps at some inadvertent remark you may have made; maybe a gesture, slight in itself, but full of significance, changes the entire aspect. The whole thing is undefinable, but as you look through the flaps of the goathair tent under which you are sitting and out on the desert you realize that the warrior Bedouin is in his right place. In a fertile country, clothed with verdure, he would be out of place; trees and buildings would spoil the picture of which he is the central figure. There is that about him which needs for its existence the great expanse of sterile nature you see around him. Elsewhere he would shrink into a mere curiosity. He would pass into the type you are apt to see at Coney Island.

The Anezeh are the most powerful of all the Bedouins; they are the greatest in war and therefore they rank the highest. They are a migrating tribe, circling the desert annually. In winter they keep near Nejd in Central Arabia, where it is warm and where the feed is better. As spring approaches they start north along the Euphrates, passing Bagdad and Deyr where they sell some of their colts and then keep on into the northern part 


\section{MY QUEST OF THE ARAB HORSE}

of the Syrian desert, near Aleppo, where they spend the summer months among the pastoral tribes.

As fall comes they start across the upper end of the desert, brushing over past Palmyra, and on down in the direction of Riad. This schedule has been in force ever since the history of the desert has been recorded.

All Bedouin Sheikhs hold their position by inheritance, and among the great sheikhs of the desert there have been some notable men. Faris, the late head of the Shammar tribe, was a man whose memory has already become a tradition. Though constantly their enemy, the greater men of the Anezeh tribe told me of his goodness and his courage. He was honesty itself. Once when his tribes had robbed some of the agricultural Bedouins of their sheep, the losers went to the great sheikh himself, and told him how his tribe had ravished their flocks. Instantly Faris told them to go and count out the same number of sheep from his own personal flocks and take them home. He was made the brother of Wilfred Blunt, Esq., twenty-nine or thirty years ago. At his death the whole desert mourned, feeling that one of the greatest of their kindred had passed away. 


\section{THE BEDOUIN OF THE DESERT}

One of the rarest souvenirs that we brought from the desert was the last seal of Faris that the Anezeh ever saw. This was a fine black impression on the pedigree of the Abeyan Sherrakieh mare, on which Moore had made his memorable ride. Although he had been their life-long enemy, the Anezeh gave it up rather reluctantly and only under pressure from Akmet Haffez.

Hashem Bey, the Sheikh of the Anezeh, has been ruling since he was twelve years old. Hc told me his tribe numbered 70,000 tents, and would average six or eight occupants to a tent. The great Anezeh are divided into many tribes and sub-tribes, chief of which is the Sebaa and the one containing the finest horses. All of the sub-tribes, however, acknowledge Hashem Bey as their highest ruler and on matters of great importance they are bound to obey his orders under their own Sheikh. They all unite when a big war is on. They own together about 300,000 camels, and unless an Anezeh has a hundred sheep and fire camels he is not allowed to maintain a tent. With that number, however, he has the right to marry four wives.

The Anezeh, as may have been gathered, [ 239 ] 


\section{MY QUEST OF THE ARAB HORSE}

are habituated to war and robbery. They believe that to cultivate the soil is to sink in the esteem of their fellow men, so they prefer to be dignified, and die, if possible, on horseback, or at their horse's feet on the field of battle. They own immense flocks of sheep that must produce fine wool as well as mutton, as they are the "fat-tailed" variety. These, with goats, and their camels, are their chief assets except what they get by robbery. They do not, as a rule, fight among themselves, but they rob the Arabs who have settled down to farming, or they war on other tribes, especially the Shammar, and its sub-tribes across the Euphrates. They fight, in the main, with the lance, but in recent years they have acquired quantities of rifles, and it is estimated that the Anezeh have several thousands of guns.

As I have said before, the true Bedouin is a gentleman. In natural politeness he is unequaled. He eats with his fingers and some of his personal habits are not pleasant, but his hospitality is unsurpassed and even if he hates you he has the knack of making his hospitality appear entirely genuine. You may be his personal enemy, as well as his tribal enemy, still, if you come and touch his tent [240] 


\section{THE BEDOUIN OF THE DESERT}

rope, he is bound to protect you; you are his guest. Young boys who had never seen a white man before, when we passed, if they were sitting, arose. When you go to a man's tent, or especially a Sheikh tent, though you may have, as we had, fifty in our party, and many animals to feed, you are his guest for three days, and he will not let you pay for anything.

To offer a tip would be an insult to the poorest Bedouin. In the middle of one night, when we stopped to drink from an old well, a ragged Arab held my horse and gave me some grapes. It was between two and three in the morning, and you can tip most of us at that hour. There was no one close enough to see him when I tried to hand him a piece of silver, but he shoved it back without a word, a thing I didn't think would be done in any country of the world. There is some answer to this, but no one seems to know what it is. I certainly do not. In Aleppo they would take money of any kind and in Beyrout you were afraid they would take your life. And on Broadway did you ever offer anybody any money at any time of the day or night and have it refused? 


\section{MY QUES'T OF THE ARAB HORSE}

If you yawn they think you are tired, and will leave you so that you can sleep. Nothing would induce them to enter your tent until you had entered it. If a Bedouin tells you the breed of a horse, or mare, you can bet it is true. They believe in just a plain simple God, and think that if they do right God will be easy to please. They marry as many as four wives, and think they are happy. When one is divorced she is kept by the tribe. Morally they are of the highest type. They don't intermarry with colored slaves. They seldom, if ever, marry out of their tribes. A Bedouin girl could not, or would not, marry the tribe's blacksmith, because of the disgrace of marrying a man who works for his living.

The Bedouin women are much like the squaws of the American Indians. They are seldom seen unless when packing the camels at moving time. They disfigure their faces by tattocing, and all of them stain the lips blue, which is a sign of beauty. Though they have to do the cooking they are never seen around the tents. The men stroll here and there as if they belonged to some great club, which in a way they do. Their Sheikh's tent is their club and there they go and come at will. There 


\section{THE BEDOUIN OF THE DESERT}

they sip black bitter coffee and talk about horses. They have great reverence for the owner of a celebrated mare, and when such a man enters a tent, those present rise, not in honor of him, but of the mare. Wars are commonly started with another tribe to get possession of a mare whose blood they want.

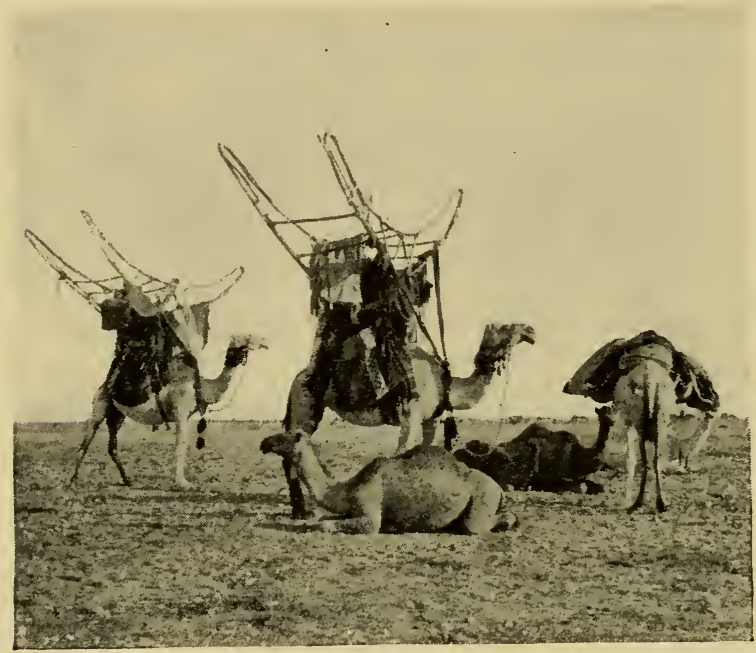

Camels for the Royal Daughters.

I do not think the Bedouin is much of a horseman, aside from being a great rider. He is kind, and has much patience, but his horseshoeing, which is the most awful in the world, proves he isn't a real horseman.

$$
[243]
$$




\section{MY QUEST OF THE ARAB HORSE}

In judging his horses he is different from the average man, and $I$ think his theory is one of the best. The Bedouins we met laughed over the few Europeans they had seen coming to buy stallions for the various European governments. These men, they said, instead of looking at the horse's head, looked first at his feet and ankles. They could not understand that. If they were going to trust me with their purses and, what was more, their life, they declared they would look first, for twenty minutes, in my face and eyes and not pay so much attention to my feet. While it was, of course, understood that a horse's legs and feet should be perfect, still a horse showed even what his legs were made of by his head and no horse was ever better or worse than what his head showed. They defied me to pick out one of the distinguished war mares that did not show her distinctive characteristics more plainly in her head than in the rest of her makeup. And I found they were right.

Horseflesh and horse-lore are the same the world over, after all. After returning to this country I told Mr. James R. Keene, the greatest of our turfmen, of the Bedouin method and

$$
\text { [244] }
$$




\section{THE BEDOUIN OF THE DESERT}

he said that he followed it himself. He told me that for years he had been in the habit of picking out, as the most likely of his colts and fillies, those which had the best heads, and he added that he had seldom been deceived. The heads showed better than the heels of what stuff the youngsters were made.

I found out from observation and experience, that whatever the Bedouin tells one about his horse, and of the horse's character, you generally find to be true. I had no opportunity of judging the truth of the statement, that when they are in war for three days the horse is better on the third day than on the first, but I did see that on the third day a small Abeyeh Sherrakieh mare, carrying Arthur Moore and his weight, carried him easier than she did on the first day.

In looking back at that summer trip in the desert I should say that we learned more than anything else to take things as they come. Of course we could not have done otherwise, but at least we learned not to complain-too much. In our general American life we complain if we are asked to eat off a table-cloth which has once been used. We rather object to drinking from a glass of water if another [245] 


\section{MY QUEST OF THE ARAB HORSE}

person has drank a sup from the same glass. We sometimes complain at hotels because the sheets are not changed more than twice a week, but all this bluff disappears quickly when we have borne the hardships of the desert in the summer time. There we found ourselves shoving a camel's head to one side so that we could drink the riled muddy alkali water from a pool; we thought nothing of being the last, after twenty Bedouins had drunk out of a wooden bowl of sour milk. After you have eaten two weeks with your hands, knives and forks seem awkward. You can, in fact, pick out with more accuracy and speed a choice piece of mutton with your fingers than you can with a spoon, and this means something when you are squatting round a meal with thirty Bedouins each with as long a reach as Fitzsimmons.

We learned to ride all day in the heat and perhaps part of the night and then be glad to lie down in a Bedouin's bed a minute after he had climbed out of it, and we ate with zest from the same mound of rice as the rest of the tribe. After all, the desert is the great leveler and it shows us how trivial and artificial we are in some ways in our civilized life. 


\section{CHAP'TER XX}

THE ARAB HORSE AND HIS PRESENT STATUSSOME STORIES FROM THE DESERT.

There has been a great deal of speculation as to where the Arab horse originally came from. He has been the subject of myth and fiction and tradition for so long that the truth about him is hard to ascertain. He has been dated as far back as Mt. Ararat by writers who gravely state that he and his companions walked off Noah's Ark and began to breed and multiply in the general region where he is now found. We are past the Ark age, however, and after all it makes little difference to the modern reader to know the exact origin of the Arab horse as long as he is what he is.

The Arab horse is a type by himself. He is distinctly different from all other horseflesh, not only in the formation of his bone structure, but in his temperament. He stands alone. It has been thought by many that there are two [247] 


\section{MY QUEST OF THE ARAB HORSE}

breeds of Arab horses - a large and a small, but that is incorrect. There is but one general breed, and this breed is subdivided into many families, all of which are different and distinct. All the families are descended from certain great historic mares.

Among the Bedouins all the emphasis is placed upon the maternal line. As long as the sire of a horse is known to be "Chubby" (meaning a thoroughbred from which an Anezeh would be willing to breed), he is of little account. The colt gets its value from the blood of the mother. That seems curious, too, in a country where women are very little more than slaves.

Ill-advised supporters of the Arab horse in this country have brought him into a great amount of criticism by trying to show that he is a racer in our sense of the word. In our sense of the word! Thank heaven he is not. The average American race-horse of to-day (I yield to no one in my admiration of such splendid animals which men like James R. Keene breed) exists simply that bookmakers and gamblers may "earn" a living by robbing the ignorant and gullible of money they cannot afford to lose. 


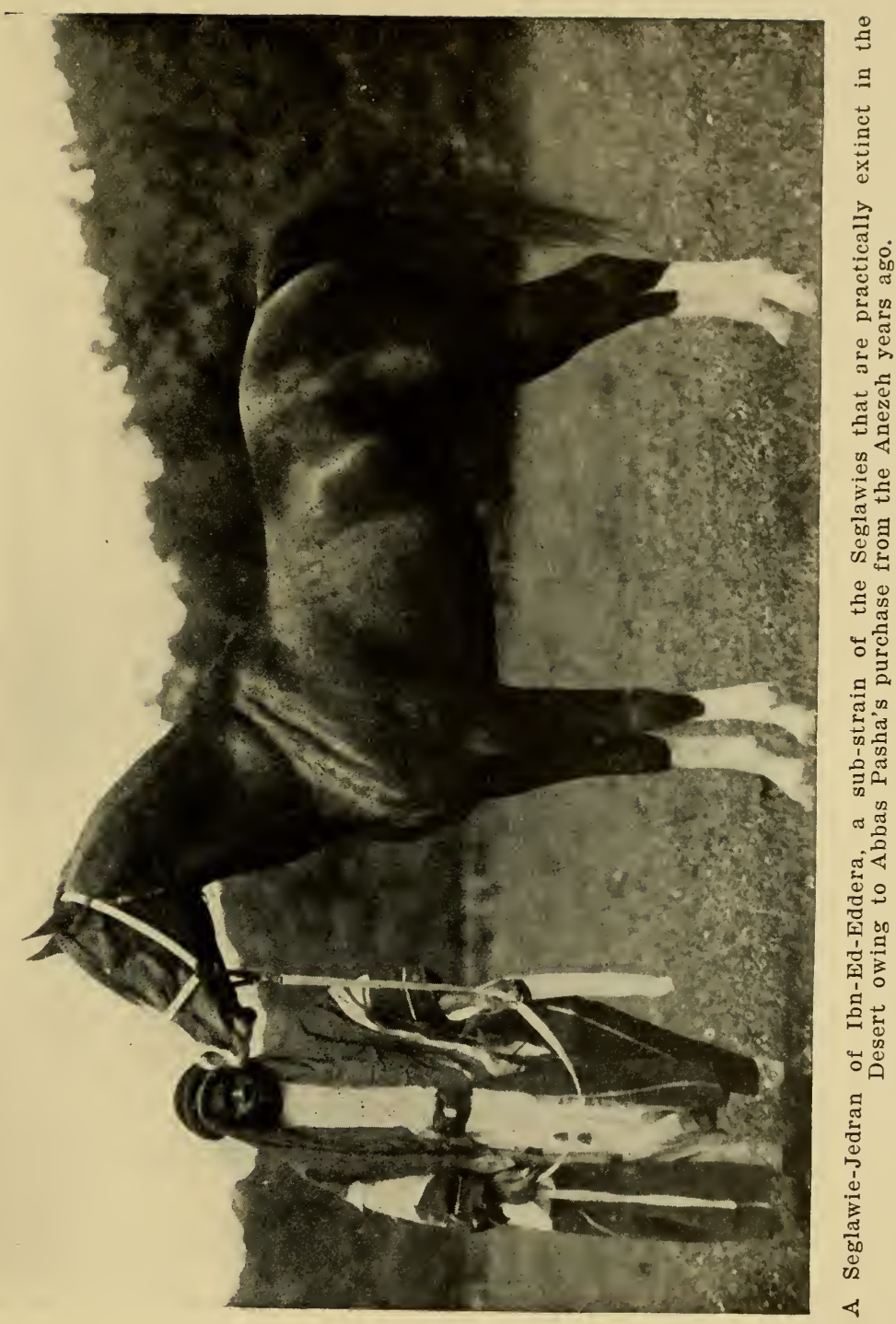




\section{MY QUEST OF THE ARAB HORSE}

Race-tracks to-day are kept alive for that one purpose. The methods of the bookmakers are almost as sure as those employed by a man who throws a gun into your face and asks you to throw up your hands. There is no escape for him. Even the honest men who race their horses for sport are his tools without knowing it.

The Arab IS a racer, but he wins through his endurance. To criticise him because he is not the equal, in short dashes, of the horses we have bred from him, is utterly unjust. To condemn him because he does not lend himself to the uses of the gambler is surely high praise.

Yet not only the modern race-horse, but his brothers of a more useful type, owe a large part of what they possess of speed, endurance and intelligence to the Arab. 'The importation into England of the Darley Arab (see appendix), and the Godolphin Arab or Barb (no one ever knew which he really was), marked a new era in horse-breeding. From them and their progenitors came most of what is best in our horses the world over. The Arab blood is to be found in the Percheron; it gives his distinction to the Russian Orloff, that most useful of horses, and it is dominant in the Han-

$$
\text { [250] }
$$




\section{STATUS OF THE ARAB HORSE}

overian, French and German cavalry horse, not to speak of some of the best types produced in England.

Is he to be condemned then simply because the only things he shows are intelligence, power, beauty, a distinct type of real poetic individuality and honesty and because he lacks extreme speed for the short distances which gamblers of the present time have set, that they may fleece the always unsuspecting public?

I have pressed the Arab horse into all kinds of service, and, in his home on the desert, I have seen him accomplish in the matter of weight-carrying, tests that I would not have believed he could have performed. In my home I have seen him on the carriage working as honestly, and as faithfully, as any horse that was ever hitched, although his ancestors knew no collars. I have seen two Arab stallions driven together by a child, in safety. His enemies will cry that he is small - that he is a pony, but that the Arab horse, in his native country, stands close to fourteen hands and two inches I have found from the examination of hundreds of them. As a matter of fact his size is merely a question of the feed given him when he is a colt, which is shown by the fact that 


\section{MY QUEST OF THE ARAB HORSE}

among the Gomussa tribe of the Sebaa Anezeh, who pay better attention to their horses than others, we found colts of two years standing fifteen hands high. At the Circassian villages on the Euphrates, where they take even better care of their live stock than the Bedouins, we found the Arab horse much advanced in size.

When you see the method of his rearing in the desert you come quickly to one conclusion. Instead of being a small horse, he is, in reality, the biggest horse known, when you consider the hardships which he goes through from the day he is born. From the first he is hobbled from fore foot to hind foot, and from fore feet and hind feet to pins driven in the ground. In that way he spends his entire life when not under the saddle. His feed consists of a nosebag full of dusty, dirty chaff and ground-up wheat and barley straw which has been threshed by the hoofs of cattle and donkeys treading over it as wheat was threshed in the days of Abraham. This dusty, dirty chaff is all he ever gets in the way of hay; and that, with a nosebag of barley, constitutes his daily rations.

I am speaking now of horses reared by the best tribes. They are watered only once a day, 


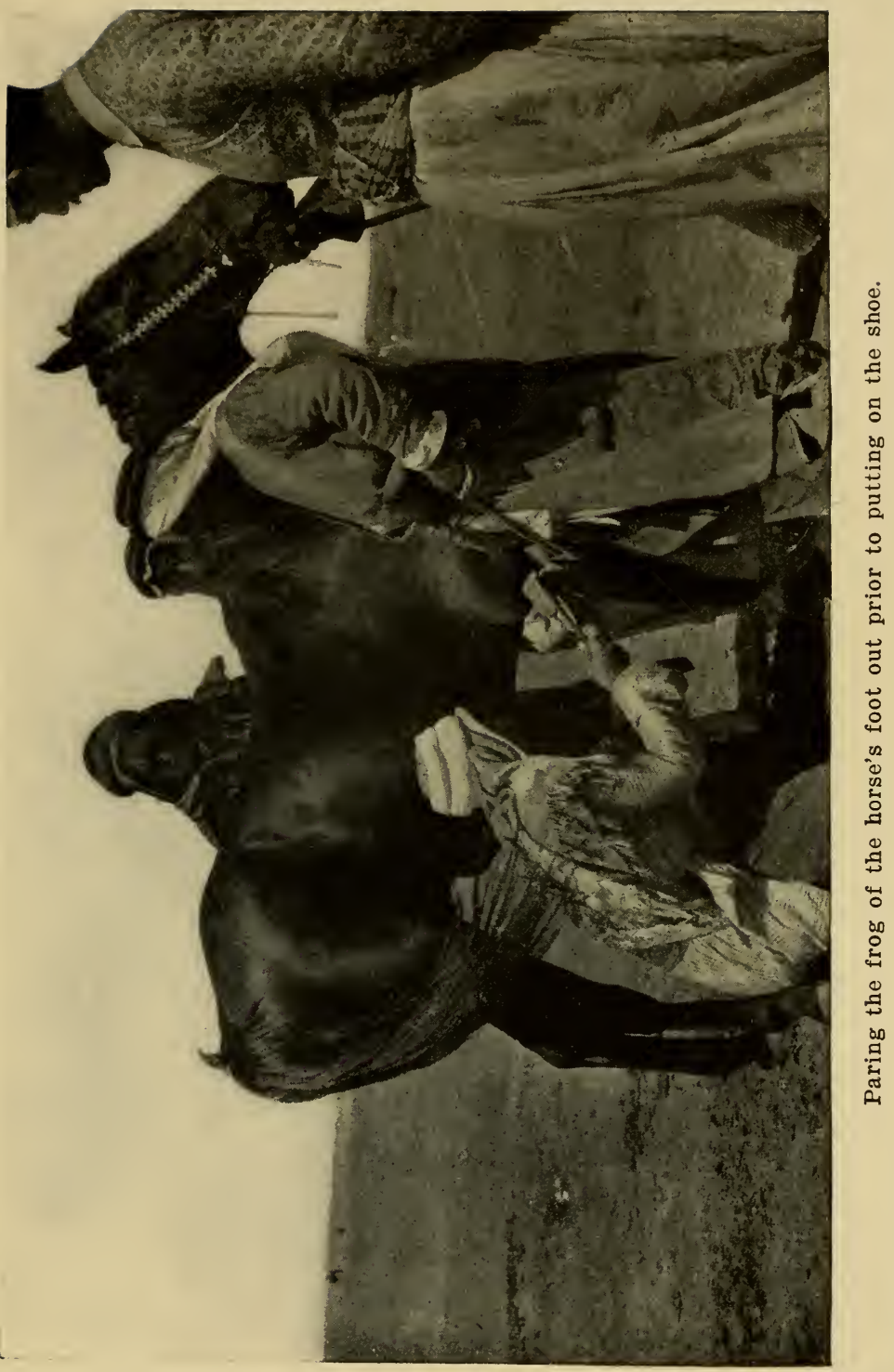




\section{MY QUEST OF THE ARAB HORSE}

and the water is a strong alkali lime mixture, which is, possibly, accountable for the great bone of the Arab horse, so finely exhibited in the skeleton of the great "Marengo," Napoleon's war horse captured on the battlefields at Waterloo. They are never taken in under shelter from the sun, neither are they protect-

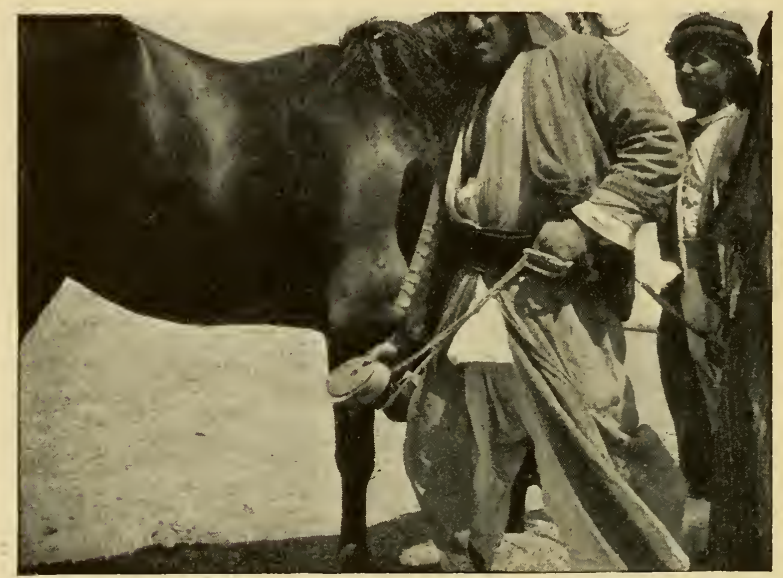

Showing the solid steel shoe with small hole in center.

ed from the storms of winter other than by a flannel blanket. The Bedouins ride them at two years old, and sometimes take them into war at three. They are shod by the so-called blacksmiths of the desert, who, in reality, are criminals, and ought to be shot. The frog of [254] 


\section{STATUS OF THE ARAB HORSE}

the horse's foot is practically cut out and then, with a didze, the hoof is made to fit the shoe, which is a solid piece of oval steel, having a small hole in the center. These shoes are nailed on with big nails.

Horses fed on this kind of food, sometimes going from twenty-four to fortyeight hours without feed or water and still able to gallop hour after hour, and day after day, without collapse, must have great powers of endurance.

In disposition the Arab horses are gentle and very affectionate. They will scratch their heads and necks on you just as they would on a hitching post. They seem to have no fear of anything, not even of man. We did see several instances where mares of the desert, which had never seen white people before, objected to our coming close to them. But that was not really fear. Some people believe that the Arab horse is a wild ferocious animal; that he is almost untameable and that he is captured on the desert with the greatest difficulty, but the most ignorance is shown as to his color In 1905, while exhibiting four stallions at the Lewis \& Clark Exposition, in Portland, Oregon, I had many opportunities of observing

[255] 


\section{MY QUEST OF THE ARAB HORSE}

this ignorance. One lady was very much surprised at seeing bay, gray and chestnut horses shown.

"All the Arabs I have ever seen working on hearses," she said, "were coal and black."

Another declared that her father had bred Arab horses as long as she could remember and that instead of being small they were large and spotted like leopards, with long flowing manes and tails. Another woman, who claimed to have been the secretary to General Colby, of Beatrice, Nebraska (the gentleman who owned the Grant stallions at the time of their death), said:

"For more than twelve years I rode the Grant stallions every day; I am quite astonished to see horses shown as Arab horses that are bay. I supposed all Arab horses were exactly like the two presented to General Grant, snow white, with pink skin and blue eyes."

Circuses are, perhaps, more to blame for the misrepresentations of the Arab horse than anything else. I have a friend who owns a circus, and I saw his posters a few years ago, claiming that he was exhibiting the only Arab 


\section{STATUS OF THE ARAB HORSE}

horses ever brought to America. He said they were captured with great difficulty and brought to New York by a special permit of the Sultan; that they were of the family known in history as the Eagle Feather Horses, so much prized in the Queen of Sheba's days; that they were snow white with black spots. I had but a few years before told my circus friend where he could find one of these alleged eaglespotted Arab horses, at Albany, Oregon, at which place, I believe, he purchased it.

How the tradition arose that the Arab horse is spotted, is difficult to imagine. The pure Arab is never spotted. That color only comes from the crossing of different breeds and that is a thing which is never done in the desert. Among the Anezeh, bay is the most common color, and white horses, though very fashionable in the desert, are very rare. During our entire travels I only saw one pure white mare, a Maneghieh Sbeyel, which I purchased. The skin round her eyes and nostrils was of a dark blackish blue, and her head was of extreme beauty. Out of a hundred mares among the Anezeh, you would find thirty-five bays, thirty grays, fifteen chestnuts, and the rest brown.

I saw only one that I would call a black [257 ] 


\section{MY QUEST OF THE ARAB HORSE}

horse, and that was a Maneghi Hedruj, of a very small size. Roans, spotted or piebalds and yellows are not found among the Arabian horses, though roans and yellows are common among the Barbs. 'The bays often have black points and generally white feet, with some white in the face. The chestnuts vary from the brightest to the dullest shades.

The Gomussa, of the Sebaa Anezeh, are the shrewdest horse-breeders of the desert, and are so recognized even by their enemies. They have kept in the largest numbers, specimens of the five families which are called the Khamseh. They also have the choicest of the sixteen other families which are rated equal in point of blood. The Khamseh, according to legend, descend from the five mares which, with other mares of King Solomon, were drinking at a river after a hard battle, when the trumpet blew, calling them back to the conflict. Only five responded to the call. It was these five which founded the five great families, of which the first is:

1-The Kenilan AJuz. This strain is numerous, and from it all other Kehilans are offshoots. 'The words Kehilan Ajuz mean "the mare of the old woman," and of course they

[258 ] 


\section{STATUS OF THE ARAB HORSE}

have a story which is this: A traveler riding a very fine mare, stopped near the middle of the day at a well owned by an old woman and asked permission to water his mount. While the mare was drinking she was giving birth to a filly colt. The traveler, being hard pressed for time, gave the colt to the old woman, so that she could care for it and rear it, if possible, on the camel's and sheep's milk. The rider proceeded on his way and rode steadily until dark, when he stopped in the open plain for the night.

At daylight he was astonished beyond measure to find that the colt he had left with the old woman, although but a few hours old, and having never really seen its mother, had made its escape and had tracked her across the desert, and was there by her side, nursing. Thus came the name. Among the Kehilans, bars are more numerous than those of any other color. They are the fastest of Arab horses, though not the hardiest, nor the most beautiful by any means. They bear a close resemblance to the English thoroughbreds to which they are nearly related. The Darley Arab, perhaps the only thoroughbred 


\section{MY QUES'T OF THE ARAB HORSE}

Anezeh horse in our stud books, was a Kehilan of the sub-family called Ras-el-Fadawi.

2-The Seglawi Family. This family descends from four great mares owned by a man of that name. At his death he gave his favorite mare to his favorite brother Jedran, and thus the Seglawi Jedrans are the favorites of the Seglawis. He gave the second mare to his brother Obeyran; the third to Arjebi, and the fourth to El-Abd, meaning the slave. Many writers consider that all four mares were full sisters. The Seglawi-Arjebi are extinct, and of the remaining strains, the Seglawi Jedran ranks first in the esteem of the Bedouins, while the Seglawi-el-Abd come second. Some years ago Abbas Pasha, Khedive of Egypt, purchased nearly all of the Seglawieh Jedranieh mares from the Anezeh tribe, paying as high, so they told me, as $£ 3,000$ for a single old mare.

3-Hamdani. The Hamdanis are not common anywhere in the desert, the Shammar being supposed to have the best. They are mostly grays, though very handsome browns and chestnuts are to be found among the Shammar. The only strain of the Hamdani which are counted "Chubby" are the Hamdani [260 ] 


\section{STATUS OF THE ARAB HORSE}

Simri, and while the Hamdani Jassel were frequently met by us, they were not considered "Chubby" by the Anezeh. The fastest walking mare I ever saw was a Hamdanieh Simrieh filly that was ridden into the desert by Akmet Haffez. She came originally from the Shammar, and was later purchased by me and brought to America. She was a dark bay four years old. I believe that in a walking contest, with the best walkers that could be found in the country, she would be five miles ahead of them at night.

Sheikh Ali, of the Abou Goumese tribe, told me of the meaning of the name Hamdani Simri, and the reason why the strain was more popular now, and yet rarer than the Seglawi Jedran. He said that once the Anezeh tribe had a great mare, a bay Seglawieh Jedranieh. She was so fast that nothing could catch her. Once, a few weeks before she was to foal, she slipped her hobbles and fled to the open desert. They went after her, but she could not be caught, and finally, when her colt came he was afraid of men and ran away and the mother followed the colt. The tribe offered rewards, but none could catch her. All of the various strains tried, Kehilan after Kehilan, but all [261] 


\section{MY QUEST OF THE ARAB HORSE}

failed. In the long run a man named Simri, who owned some horses of the Hamdani breed, came with a big horse with full round belly and offered to catch the mare and colt. The Anezeh laughed at him. The horse had to be beaten to make him even walk fast. But the man insisted to be allowed to try and the second day the horse went better and began to show spirit. Finally the Anezeh took the man to the place where the mare went daily to drink and told him to try his luck. At noon the mare and her colt came and when the latter saw the horse, and the people, he fled. The Hamdani, to the surprise of all, gave quick chase and in four hours the colt was captured and bound. 'Three hours after, the mare was captured, and from that time the breed was known as the Hamdani Simri, and since that day has been the favorite over the Seglawi Jedran.

4-Abeyan. The Abeyan is the handsomest of the five breeds, but is small and has less resemblance to the English thoroughbreds than any of the other families. The Abeyan Sherrak is the most esteemed of the seven strains of the Abeyan, there being but two others of that seven, the Abeyan Zahaine and [262] 


\section{S'TATUS OF THE ARAB HORSE}

the Abeyan Fadaha, which are counted "Chubby." The name Abeyan is derived from the word "Aba" (cloak), and comes from the following incident: A certain Arab, probably of the name of Sherrak, being pursued in war, lost his way just as night was coming on. $\mathrm{He}$ believed that his mare could run all night and save him from his pursuers, but fearful that his heavy Aba, or cloak, might hinder her stride, he loosened it, and throwing it off over his shoulders thought he noticed that during the remainder of the night the mare ran steadier and more smoothly. The mare easily outstripped his pursuers, but when daylight came Sherrak found that his cloak had not been lost. It had been caught by the mare's tail, which is carried higher by this breed than in any other family of Arab horses.

5-HadBas. There are five strains of the Hadban family. The Hadban Enzekhi is the favorite, and the Hadban al-Fert is the only other that is considered "Chubby" by the Anezeh. The Gomussa of the Sebaa Anezeh are supposed to have the best of the breed. Browns and dark bays are the favorite colors of the Hadban Enzekhi, and a mare and filly 


\section{MY QUEST OF THE ARAB HORSE}

colt twenty days old, which I bought, were the finest specimens we saw.

Besides these five families, there are sixteen other breeds which are counted as equal to the Khamseh. First is the Maneghi, supposed to be an offshoot of the Kehilan Ajuz. The characteristics of this breed are marked. They are plain and without distinction, being somewhat coarser with longer necks, powerful shoulders, much length, and strong but coarse hind quarters. They are strong-boned, and are held in high repute as war horses. There are four families, the favorite being Maneghi Sbeyel, which is regarded "Chubby" all over the desert. Maneghi Hedruj, the next esteemed, was not counted "Chubby" at Nejd, but was by some tribes of the northern desert. The brown stallion "Halep," which was my present from the Governor of Aleppo, and was looked upon as the best stallion the Anezeh owned, is a Maneghi Sbeyel, dark brown without a white hair. His mother, his grandmother, his great-grandmother indeed, all his maternal ancestors for two hundred years had been the spectacular war mares of their time. The other breeds are as follows:

Second-Saadan, often very beautiful

$$
\text { [264] }
$$




\section{STATUS OF THE ARAB HORSE}

horses, with the substrain Saadan Togan as the most highly esteemed.

Third-Dakhman.

Fourth-Shueyman.

Fifth-Jilfan. The substrain Jilfan Stam el Bulad is in some parts of the desert prized equally with Hamdani Simri.

Sixth-Toessan.

Seventh-Samhan. (Substrain Samhan el Gomussa. The horses of this family are frequently very tall, and are much esteemed.)

Eighth-Wadnan. (Substrain Wadna Hursan.)

Ninth-Rishan. (Substrain Rishan Sherabi. Of these we saw many very beautiful grays.)

Tenth-Tamri. ('The Kehilan Tamris are highly prized, and the bay two-year-old we bought of this family is a picture.)

Eleventh-Melekhan.

Twelfth-Jereyban.

Thirteenth-Jeytani.

Fourteenth-Ferejan.

Fifteenth-Treyfi.

Sixteenth-Rabdan.

Besides these, there are the Kehilan Heife, Kehilan Kroash, Kehilan al-Denais, Kehilan [265] 


\section{MY QUEST OF THE ARAB HORSE}

al-Nowak and the Kehilan al-Muson, or the listening horses. This latter family descends from a mare that, so the story goes, once stood motionless all day in the desert, listening. The Bedouins came around and looked at her with awe. There was no question that she heard something in the distance. They finally took off her hobbles, and she ran about in circles and then stopped and snorted. Again she stood still and listened, first with one ear forward and then with the other. They brought a nosebag with barley and put it on her head. From this she would take a mouthful and then pause for a minute or two, still listening. The Bedouins could not tell from what direction the sound she evidently heard came from. They thought it might be a message from Allah.

The same night one of the most awful massacres recorded in desert history took place, and more than half the men of the tribes were slaughtered. From that time the descendants of the listening mare have been venerated.

While there are not two distinct breeds of horses in the desert, there are, however, a first and second class. A horse, or mare, about whose breeding there is the slightest doubt, is

[266 ] 


\section{STATUS OF THE ARAB HORSE}

of the second class, and is not called "Chubby." Even horses taken in war, previous to ten years ago, would not have been called "Chubby." In all cases the breed of the colt is that of its dam, and not of its sire. A colt whose father is a Hamdani Simri, and whose dam is a Seglawieh Jedranieh, would necessarily be a Seglawi Jedran.

The Arab in his purity is a horse of the highest courage. In stature, as I have said before, he stands fourteen hands and two inches high and is more often a little under than over that. $\mathrm{He}$ is a very perfect animal; he is not large here and small there. There is a balance and harmony throughout his frame not seen in any other horse. $\mathrm{He}$ is the quintessence of all good qualities in a compact form.

The beauty of his head, ears, eyes, jaw, mouth and nostrils should be seen to be appreciated. The ears are not small, but are so perfectly shaped that they appear small. The head is short from the eye to the muzzle and broad and well developed above. The eye is peculiarly soft and intelligent with a sparkle characteristic of the breed. Yet when it lights up with excitement it does not have the strained wild look, and pained, staring expres-

[267 ] 


\section{MY QUEST OF THE ARAB HORSE}

sion often seen in European horses. The nostrils, long and puckered, are drawn back and are capable of great distention. The neck is a model of strength and forms a perfect arch that matches the arch of his tail. The throat is particularly large and well developed. It is loose and pliant when at rest, and much detached from the rest of the neck. This feature is not often noticed, though it is indicative not only of good wind, but of prolonged exertion without distress, owing to the great width between the jaws. The two great features, possibly, that a novice would notice quickest in the Arab horse, is the forehead, or jibbah, which cannot be too prominent, and the other is the tail set high and carried in an arch.

The build of the Arab is perfect. It is essentially that of utility. The space for the seat of the rider at once fixes his true position and his weight is carried on that part of the frame most adapted for it. If he be carefully examined it will be found that all the muscles and limbs of progression are better placed and longer in him than in any other horse. Nature, when she made the Arab, made no mistake, and man has not yet been able to spoil him.

[268] 


\section{CHAPTER XXI}

VARIOUS IMPORTATIONS OF ARAB HORSES

Mary importations of Arab horses have been made out of the desert since Darley's came to England in 1703. Some, of course, were not the best blood; but, to say that there have been no thoroughbreds brought out of the desert, would be as preposterous a statement as to say that the only known thoroughbreds of the Arab blood were to be found on someone's private estate.

Of modern importations, I believe those of Mr. Wilfrid and Lady Anne Blunt, owing to their extensive travels in the desert, have been as good as any. Many of their choicest mares were purchased in towns and not in the desert, but their knowledge of the breed is extensive and they could not be deceived.

Many Arab horses have been brought to America and credit must be given to the late A. Keene Richards who, in 1855 , or 1856 , went [269] 


\section{MY QUEST OF THE ARAB HORSE}

from his home in Kentucky to Palmyra, and brought three stallions and two mares. Mr. Richards bred his stallions extensively and one of their get, "Sabek," was bought by Mr. Aymar Van Buren, of Newburgh, N. Y. Mr. Van Buren brought the half Arab to Newburgh, where he sired a great many very fast and tough road horses with extra endurance.

For many years in the meantime, Mr. Randolph Huntington, of Oyster Bay, had been a student of the Arab horse. Mr. Huntington was the breeder of Henry Clay, and still maintains much of that blood on his farm. His ideas, however, were very different from those of the majority. He believed in in-breeding, and considered that that in itself was a test of purity of blood. He bred his Arab mare "Naomi," which was bred by the Rev. F. F. Vidal, in England, to her son, and grandson. That cross did not strike the fancy of the American horse-breeders, and Mr. Huntington and the horse-breeders of America have long been at war. Indeed his efforts so far as they were intended to demonstrate what the Arab horse can do in America, have been a failure.

Several horses have been imported into [270] 


\section{IMPORTATIONS OF ARAB HORSES}

America from the Blunts. The best stallion of the lot was a small white Dahman Shahwan, an imported horse brought from Abbas Pasha in Cairo by the Blunts, and sold later to Mr. J. A. P. Ramsdell, of Newburgh, N. Y. But after he had sired one pure Arab filly out of the gray mare "Nedjma," of the Chicago World's Fair importation of 1893, he died.

To the World's Columbian Exposition, at Chicago, came several mares and stallions from near Damascus, under a special permit of the Sultan of Turkey. By the direction of the Sultan, the so-called Hippodrome Company, which imported the horses, was to return to the desert after the fair was closed. But that was never done. The company became entangled in debt, and eventually the horses were sold at public auction, most of them being bought in by the holders of a mortgage. Previous to the foreclosure, through a religious wrangle, nine of the very finest horses and mares were burned to death in an incendiary fire, together with all their pedigrees except one. That pedigree belonged to the finest animal of the lot, the gray mare called "Nedjma." It was taken to California by a young Syrian, who hoped to get a reward for its return. The horses were 


\section{MY QUEST OF THE ARAB HORSE}

much abused by some of the Arab horse critics in America, who claimed that they were tram horses from Damascus; but as there are no trams in Damascus, the point was not very well taken. On the contrary I am assured on good authority that the World's Fair horses were of the best blood and that among them were very fine specimens of the Hamdani Simri, Abeyan Sherrak, Seglawi Obeira, and others of the recognized breeds.

There is one noteworthy fact in connection with these animals and that is that they are the only Arab horses which ever came to America, and won a prize in an open competition in any class at the recognized horse shows in America. Mr. Peter B. Bradley, of Hingham, Mass., who had bought nearly all of them, bred a colt which won a prize in open competition, at Durland's Horse Show, for light-weight saddle horses. Another yearling colt bred by Mr. Bradley and sired by "Obeyran," one of the World's Fair stallions, out of a mustang mare, won first prize in open competition at the New York State Fair in 1903, beating several of the get of the best bred trotting horses in the country, while a bay horse, "Zedan," bred by Mr. Bradley, out of pure sire and dam, 


\section{IMPORTATIONS OF ARAB HORSES}

is the only Arab horse I have seen that ever showed any real pretence toward the trotting gait. This horse can road from twelve to fifteen miles an hour, and keep it up all day. Mr. Bradley used his horses constantly; drove them as well as rode them, played polo on them, and their performances have amounted to more in the few years that he had them, than those of all the rest of the Arabs that ever came to the country. The other imported horses, up to that time, and for some years later, had been kept in their box stalls only to be admired as idle pets.

The two stallions which were presented to General Grant when he visited the royal stables at Constantinople, were both grays. Mr. Huntington had used both stallions on his farm, after they were taken to the Genessee Valley, and thence to Beatrice, Nebraska, where they both died. "Leopard," a light gray, broke his leg and had to be killed, while "Linden Tree" lived for several years after, dying in 1900. General Colby, who owned them at the time of their death, crossed them largely with western mares, and bred some very fine colts.

Among the breeders of Arab horses in [273] 


\section{MY QUEST OF THE ARAB HORSE}

America few have been more prominent than Mr. J. A. P. Ramsdell of Newburgh, who purchased the finest of the World's Fair mares in "Nedjma." Mr. Ramsdell later bought "Graraveen," sired by the great racing Arab, "Kismet," out of "Cushdell Bey," the Rev. F. F. Vidal's favorite Arab mare in England. "Garaveen" sired some very fine types out of the mare "Nedjma," and also out of her daughter by "Shahwan." "Garaveen," at the present writing, is the only living son of the great and unbeaten "Kismet."

For a number of years Mr. Spencer Borden, of Fall River, Mass., bred Arabs. He had received some mares from the Hon. Miss Dillon, of England, and had bred from Mr. Huntington's stallions; later, purchased from Mr. Bush Brown, the sculptor, the Russian Arab "Gouinad."

This horse was brought to the World's Fair in Chicago, in 1893, in the Russian Government exhibit, and would rate as a high-class Arab, though not of pure blood, tracing, on one side, to a Turkoman cross. Mr. Borden's recent importations, however, from the Blunts, were all very fine blood, and mostly of the Kehilan Ajuz family. 


\section{IMPORTATIONS OF ARAB HORSES}

My own importation reached America on October 8, 1906, and consisted of ten mares and seventeen stallions. Two of the stallions belonged to C. A. Moore, Jr., and one to J. H. Thompson, Jr. Another stallion which Mr. Thompson bought in Beyrout reached America about ten days after my importation, and only a few days previous to the National Horse Show in New York City. He was entered by Mr. Thompson in the class for sires of polo ponies, and in competition with seven, won third prize. This stallion, mind you, was competing against thoroughbreds and was at a disadvantage, being in reality too large for the class. He was a three-year-old bay, standing fifteen hands high.

James W. S. Langaman brought to America, in 1903, a golden buckskin stallion with black mane and tail, standing fifteen hands three inches. He came to my farm from the steamer, and remained there several months before being shipped to Governor Francis, in St. Louis, at the opening of the World's Fair. Mr. Langaman at that time returned to Morocco and came back with six scrubs, the rankest mongrels that ever crossed the ocean. He purchased them at Tangiers, possibly pay- 


\section{MY QUEST OF THE ARAB HORSE}

ing $\$ 30$ for the highest-priced one. He tried to palm them off as Arab horses, and gained a lot of newspaper notoriety through his efforts to present them to the President of the United States, claiming that they had been sent by the Sultan of Morocco. The horses were, of course, refused, and were later sold at a foreclosure sale at the American Horse Exchange, where one brought the remarkable price of $\$ 120.00$. They were all foundered and otherwise crippled.

From such specimens as these, and the bigflanked spotted circus horses, the Arab horse has suffered much injustice. If he recovers from this it will have to be by his own efforts. In exploiting the Arab horse, I shall not go beyond their ability to carry out promises for them.

Tamam

[276] 



Webster Family Library of Veterinary Medicine

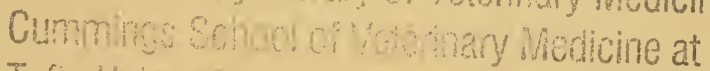
Tuts Uhibenich

200 Westboro Road North Grafton, MA 01536 

